\title{
BURYING A SAGE: THE HEROON OF THALES IN THE AGORA OF MILETOS
}

\author{
With remarks on some other excavated Heroa and on cults and graves \\ of the mythical founders of the city*
}

\author{
Alexander Herda \\ Rotdornstr. 1, 12161 Berlin \\ alexander.herda@web.de
}

for Josefine Schmitz (19.3.1919 - 9.4.2003)

\section{Abstract}

This article adresses the heroon of Thales in the agora of Miletos, so far only literarily attested ( $\S$ IV, VII). The sage was worshiped as secondary founder, having the status of a 'cultural hero', an age-old Indo-European concept. Graves of founders are typically placed on the agora $(\S \mathrm{V})$, but not those of the mythical founders of Miletos, Asterios, Miletos and Kelados or Ionian Neileos ( $(\mathrm{VI})$. Of the intramural heroa excavated in Miletos none can claim to be that of Thales: Neither 'Heroon I (the grave of the Macedonian general Dokimos?), II and III' ( $($ I), nor the 'Ehrengrab' in the courtyard of the Hellenistic bouleuterion, which is most likely an altar ( $(I)$. Instead, a thesauros in the assembly hall may have served as a heroon ( $(\mathrm{III})$, and the philosopher Anaximander may also have recieved cult in the bouleuterion ( $\S$ VIII). Finally, a chamber tomb slightly west of the bouleuterion is discussed ( $(\mathrm{IX})$. At the end some general remarks on Greek hero cults are added, stressing the common concept of the immortal divine soul, again an Indo-European heritage, manifest for example in the apotheosis of the Hittite kings as well as that of the Roman emperors $(\S X)$.

\footnotetext{
* Countless thanks go to Olivier Henry for having organized the conference, giving me many advices, being a perfect host and staying so patient with authors who need more time to finish their articles!

This piece is devoted to the memory of my grandaunt Josefine Schmitz, teacher and friend, who always encouraged me to study archaeology and history and ask what's behind human beliefs and knowledge. It was written in the inspiring atmosphere of the library of the German Archaeological Institute at Athens to whose always helpful staff, Soi Agelidis, Christina Zoiga and Katharina Brandt, are adressed my warmest thanks. The English was corrected by Robert Hahn, of whose keen insight into early lonian philosophy I profit a lot. The figures were improved with the ingenious skills of Stefan Gräbener.
} 


\section{Summary}

The ancient Greek city of Miletos on the western coast of Asia Minor was famous for her philosophers. The first and most famous of them was Thales, who - according to the common tradition starting in the $6^{\text {th }}$ century $\mathrm{BC}$ - even won the Panhellenic contest of the Seven Sages. His grave is only known from literary sources, describing its location, appearance and inscriptions (§§ IV, VII). Nevertheless, recent research has revealed new data on the geoarchaeology and townplanning of Miletos that provokes a first attempt to locate and reconstruct the grave. The myth goes that Thales, who died in the mid $6^{\text {th }}$ century $B C$, himself choose the place. Later on, it happened that his grave became located in the agora (Plutarch, Solon 12). In ancient times, this prominent place was reserved for the heros ktistes, the heroic founder of a city, as Pindar (Pythian 5.93) has pointed it out for Battos in Kyrene. It is argued that Thales was indeed venerated as a kind of secondary founder in the sense that he achieved the status of a 'cultural hero', a concept long-established in the Indo-European tradition. His heroon is expected to be found somewhere in the area of the so-called North Market, the political agora of Miletos, which was included in the $6^{\text {th }}$ century $B C$ public building programme. The whole northern city-half around the Lion Harbour and the sanctuary of Apollo Delphinios was re-organized in an orthogonal streetinsula-grid. It is tempting to suppose that Thales himself took part in its planning. After all is he the archetype for the geometer Meton in Aristophanes Birds of 414 BC, who creates 'Cloudcuckouville', the phantastic new town of the birds in the sky, round in shape with an inscribed square and an agora in the centre, reachable via radiating streets; Aristophanes lampoons Meton as taking the set square and squaring the circle! The response is that this man is a veritable Thales! Later in the $4^{\text {th }}$ century $\mathrm{BC}$ an honorary statue may have been added to the heroon of Thales, of which a copy of the head may have survived on the famous double herm with Bias in the Vatican. The inscription, cited by Diogenes Laertius (1.34), stresses Miletos' claim for being the "ornament of Ionia" (Herodotus 5.28), offering its 'crown jewel', Thales, to the goddess of wisdom, Sophia.

An extra chapter is devoted to the graves of founders (heroes ktistai) on Greek agorai ( $\S \mathrm{V}$ ).
The examples of Battos in Kyrene, Pammilos and Euthydamos in Selinous, and Aratus in Sikyon show that the grave of a city founder, as well as that of other kinds of heroes, was exempted from the idea of ritual pollution (mysos, miasma). Instead it counted for being katharos, "pure", or an asebema, an "impious", "profane" location and equally the festivities for founders are designated as hosia, "profane", meaning that they where not forbidden by divine, and in consequence, by human law. Also evident from these examples is the connection of ancestor cult to hero cult: in Kyrene as well as in Selinous and perhaps also in Athens, the cult of the founders is tied to the cult of the anonymous, collective ancestors of the polis, the Tritopatores.

Looking aside, the intra-mural heroa excavated so far in Miletos, 'Heroon I, II and III', are briefly analysed $(\S I)$. A special focus lies also on the Hellenistic bouleuterion. It included the 'Ehrengrab' in its courtyard ( $(\mathrm{II})$, an underground chamber in its assembly hall ( $(I I I)$, and an Archaic votive statue of one Anaximander, presumably the pupil of Thales ( $(\mathrm{VIII})$. Finally, a subterranean chamber tomb slightly west of the bouleuterion is discussed ( $\mathrm{IX})$. None of these can claim to be the heroon of Thales, which has yet to be found. 'Heroon I' is a Macedonian chamber tomb in its earliest phase and likely the grave of the Antigonid general Dokimos and his family, who had reinstated Miletos' autonomy and democracy in $312 \mathrm{BC}$, and after whom the close by Lion Harbour got the name 'Harbour of Dokimos'. The Hellenistic-Roman 'Heroon II' is situated close to the largest gymnasium of Miletos, where a famous Milesian athlete may be the owner. We know for example of a certain Antenor, Olympic champion of $308 \mathrm{BC}$ in pankration, who got a heroon in the middle of the gymnasium of the neoi. $2^{\text {nd }} / 3^{\text {rd }}$ century AD 'Heroon III' also lacks clear epigraphical evidence of an owner. Its ClassicalHellenistic forerunner seems to have been the club-house of a religious association for Apollo Didymeus.

A critical amendment of the Augustan so-called Ehrengrab in the courtyard of the bouleuterion reveals the first interpretation by excavator Th. Wiegand as an altar of Artemis Boulaia the most likely. Artemis will have been joined by Apollo Didymeus and Zeus Boulaios. The typological proximity to the Ara Pacis Augusti in Rome as well as the presence of two Imperial priests in the honorary inscriptions on the bouleuterion walls 
indicate that the altar also served the Imperial cult. According to the situation in Athens, Augustus will have been paired with Zeus Boulaios, while Livia equated Artemis Boulaia. The priests, Gaius Iulius Apollonios and his son, Gaius Iulius Epikrates, stemming from one of the first families of Miletos with close contacts to the lulii since Caesar's times, are honored as heroes in the wall inscriptions. It is proposed that an underground chamber in the eastern corridor of the assembly hall, originally a thesauros, served as their heroon. The situation is compared with the former city thesauros in the agora of Messene, which was transformed in a heroon of Philopoimen, after he had been locked and died within it.

Another find in the bouleuterion is an Archaic female statue, dedicated by one Anaximander. Having in mind the importance of bouleuteria for the self-conception of Greek cities and the fact that they often serve as location of hero cults, as well as the role Anaximander played as Thale's closest pupil and figurehead of the Milesian school of philosophers, we may assume a hero cult of Anaximander in the Hellenistic bouleuterion. Comparable to this situation is the location of the heroon of the sage Bias in the prytaneion of Priene.

The subterranean chamber, recently suggested to be the Archaic grave of some Milesian founder and located in the assumed agora of that time, is neither Archaic, nor located in the agora ( $\S \mathrm{IX}$ ). Instead, the chamber is dated Hellenistic and overbuilt by a house complex, presumably the local of a burial- and cult-association. Such associations are attested in several Hellenistic inscriptions from the necropoleis of Miletos as well as from the city itself. They are called temenitai or temenizontes and were, at least partly, non-citizens, metoikoi.

The graves of the mythical founders of Miletos are also discussed ( $(\mathrm{VI})$. Only that of Minoan Miletos was located within the city, though its exact place is unknown. In contrast is the grave of indigenous giant Asterios to be found on an island called 'Asteria' north of Miletos, while Kelados, the son of Miletos, is most likely an immortal river god without a grave, having his sanctuary at the processional road to Didyma. The grave of Ionian Neileos was shown outside the city walls, close to the 'Sacred Gate'. Its position in the necropolis can best be explained by assuming an old family grave of the Neleidai, the descendants of Neileos. A late Hellenistic monumental marble cuirass may be ascribed to this heroon, while a statue of Neileos stood in the agora in front of the bouleuterion.

At the end of this paper, some general remarks on Greek hero cults are added $(\S X)$. To my mind essential is the origin in the Indo-European believe of the immortal, divine soul, connecting the humans with their gods. By means of the separating and purifying ritual of cremation, the soul of the heroes could get in direct contact with the gods after apotheosis, and join them on Olympus like Herakles did, or being visited in the Elysion resp. 'island of the Blessed' like Achilles or the Pythagorean or Bacchic-Orphic Mystai. The re-unification with the gods, reconstructing the very beginning of the cosmic order, when gods and humankind lived together in the 'Colden Age', can be seen as main aim of this eschatological believe. We therefore find impressive correlations with the apotheosis of Imperial Hittite and Roman funeral rituals. In both latter cases the aspect of the divine souls as 'minor gods', interacting with the living people by protecting them and garanty their reproduction, becomes clearer. Therefore the cult of the dead ancestors cannot be separated from the cult of the heroes, both are apects of the same phænomenon. This becomes most evident, when something new is created: the cult of the founder, the heros ktistes of a Greek polis state, is commonly combined with the cult of the Tritopatores, the anonymous, collective ancestors of the polis.

Of course the belief in the immortal divine soul was always doubted by clever people. Aristophanes in his comedy Birds was one of them, Seneca in his satire Apocolocyntosis another.

\section{The heroa in the city, other than that of Thales}

The extramural necropoleis of Miletos have been the subject of different recent studies, including the, so far, unpublished PhD-thesis of Elke Forbeck, the edition of the grave inscriptions within the corpus of the Milesian inscriptions by Peter Herrmann, Wolfgang Günther and Norbert Ehrhardt, and an upcoming article of Kaja Harter-Uibopuu and Karin Wiedergut on the measures to protect the graves in Roman Imperial times'. However, it was never

\footnotetext{
1 Forbeck 2001/2002; Forbeck 2002 and forthcoming; Forbeck/Here 1997; grave inscriptions: Herrmann 1980; Herrmann 1995; Herrmann 1998, 159 no. 29, 145 f., 217 nos. 398 f.; Herrmann 1998, 1-88
} 


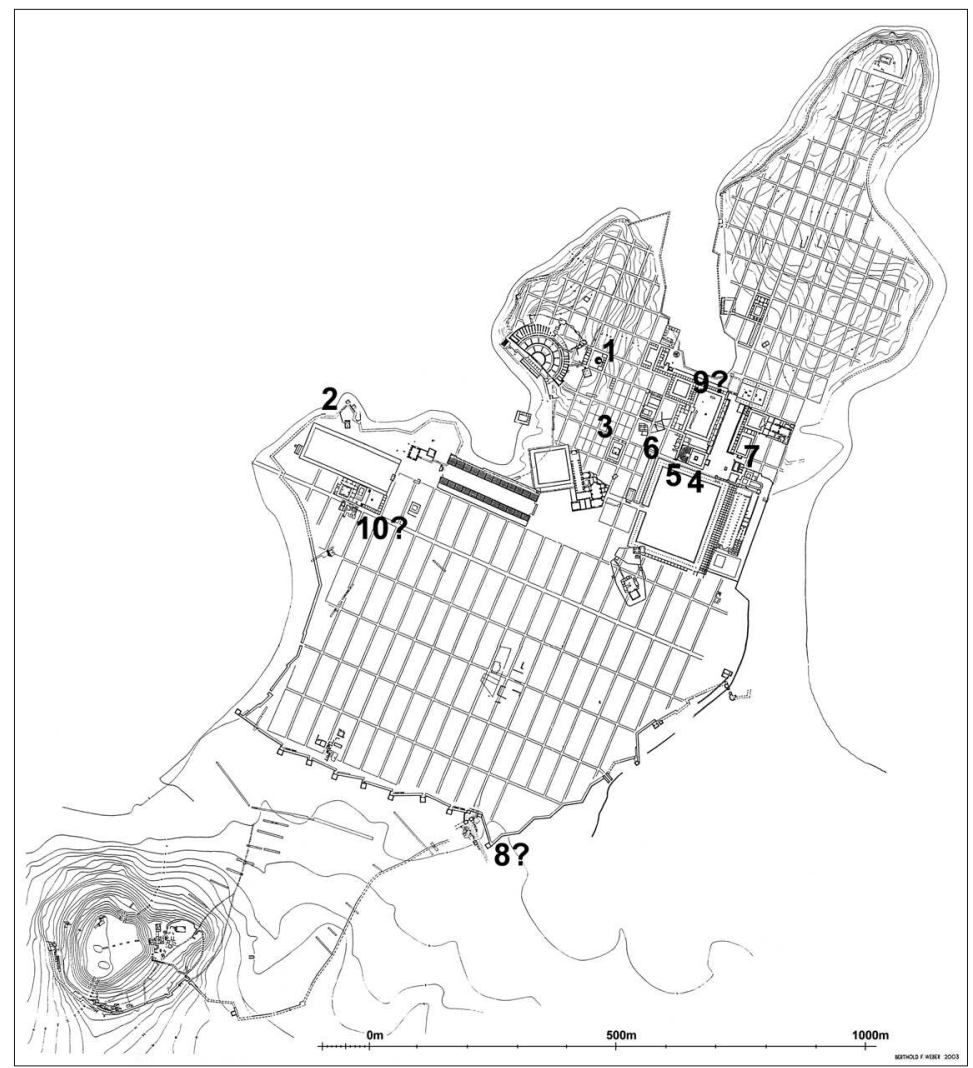

Fig. 1:

City map with location

of Milesian heroa:

Heroon I (1), Heroon

II (2), Heroon III

(3), 'Ehrengrab' (4),

chamber in assembly

hall of the bouleuterion

(5), subterranean

chamber west of the

bouleuterion (6), statue

basis of Neileos in

front of nymphaeum

(7), grave of Neileos at

Sacred Gate (8, exact

location unknown),

heroon of Thales

(9, exact location

unknown), heroon

of Miletos (10, exact

location unknown)

(drawing author after

Weber 2007, Beilage 3).

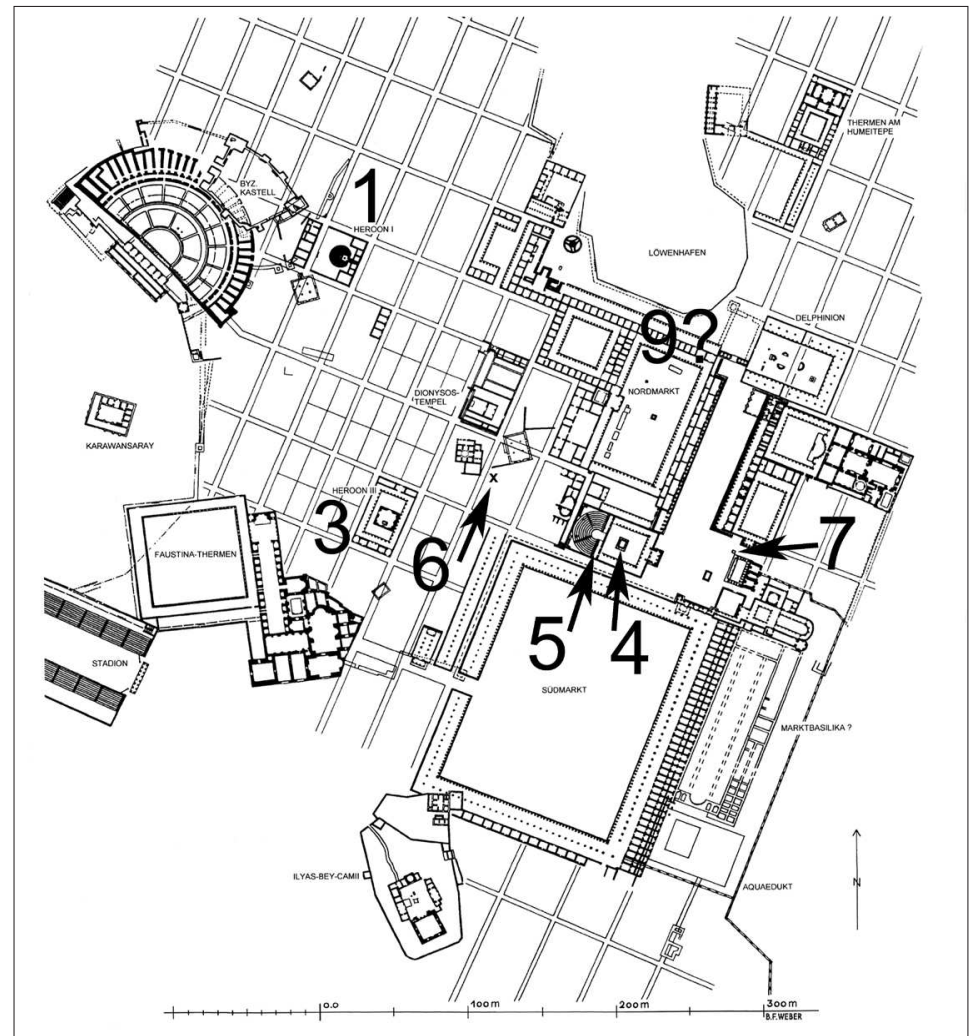

Fig. 2 :

City center of Miletos with location of Heroon I (1), Heroon III (3), 'Ehrengrab' (4), chamber in assembly hall of the bouleuterion (5), subterraneran chamber west of the bouleuterion (6), statue basis of Neileos in front of nymphaeum (7), heroon of Thales (9, exact location unknown) (drawing author after Weber 2007, 352 fig. 17). 
attempted to give a complete overview over the many intramural heroa ${ }^{2}$, the excavations and studies in Miletos have revealed in the last 113 years of research?3.

Before I deal with the intramural grave of Thales in Miletos, let me therefore start with some other graves within this city which are much better known and which have the great advantage that we know at least how they looked like. I refer to the so-called Heroa I, II and III, as well as to the so-called 'Ehrengrab' in the Hellenistic bouleuterion (see § II), and the underground chamber in the assembly hall of the bouleuterion (see $\S$ III). They are all located around the city center (figs. 1-2).

\section{Heroon I (figs. 3-5, 11)}

Heroon I is located on the slope east of the theatre and covers a whole insula of the street-insula-grid4. This insula is not as long as the other insulae: in the North and South it measures $33.90 \mathrm{~m}$ instead of c. $52 \mathrm{~m}$, while the West-East width of $28.20 \mathrm{~m}$ is regular (fig. 2, 1) $)^{\text {. }}$. Perhaps the stripe of shorter insulae was originally left free from buildings, connecting the northern agora and the Delphinion with the area of the prominent Theatre Hill top, where we have to assume a fortress (phrourion) since at least Classical times (see below). This open space also helped to mediate between the streetinsula-grid systems west of the agora, possibly determined by the position of the sanctuary of

nos. 407-786; Herrmann et al. 2006, 247-250 nos. 1404-1418; Ehrhardt/ Günther 2010; Harter-Uibopuu/Wiedergut forthcoming. On the basileion/archeion/grammatophylakion as archive of Miletos, where the common and individual grave regulations as well as the grave register were kept (the archive was not located in the Delphinion): Herda 2006a, 233 f., 434 and 2011, 67.

2 The most recent and complete is Schörner 2007 on Heroa I, II and III (see §I) and the Ehrengrab in the court of the Hellenistic bouleuterion (see §II). But missing are the heroa of Thales (see §§ IV, VII), the underground chamber in the assembly hall of the Hellenistic bouleuterion (see § III), Anaximander in the bouleuterion (see § VIII), and the subterranean chamber tomb west of the bouleuterion (see §IX).

3 German excavations in Miletos started in 1899. Let us hope that they can be continued in an intelligent collaboration with our Turkish hosts and international colleagues!

4 Kleiner 1968, 129-131 figs. 96-98; Schörner 2007, 237 f. A16 figs. 86-94. The reconstructions of Kleiner 1968, 130 fig. 97; MüllerWiener, $\operatorname{MDAl}(\mathrm{I})$ 35, 1985, 19 fig. 1 (= here fig. 3); Kader 1995, 227 figs. 3, 6 and Schörner 2007, figs. 87-88 are incorrect as the row of chambers in the west is not part of the Heroon l-insula but part of the next insula to the West and devided from it by a $4 \mathrm{~m}$ broad North-South-street: see Weber 2007, 352 f. fig. 17. 5 Weber 2007, 352 f. fig. 17.

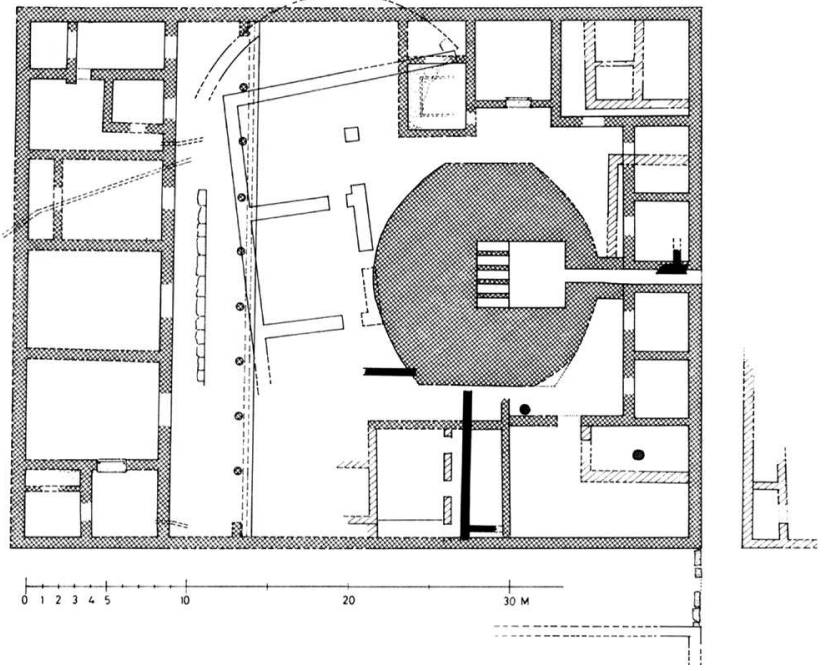

Fig. 3 : Heroon I, ground plan; black: phase I (Early Hellenistic), cross-hatched: phase II (Hellenistic), hatched: phase III (Roman Imperial), empty: phase IV (Early Byzantine). Note that the street, separating the western row of rooms and the Heroon-insula, is not designated (from W. Müller-Wiener, $\operatorname{MDAI}(I)$ 35, 1985, 19 fig. 1).

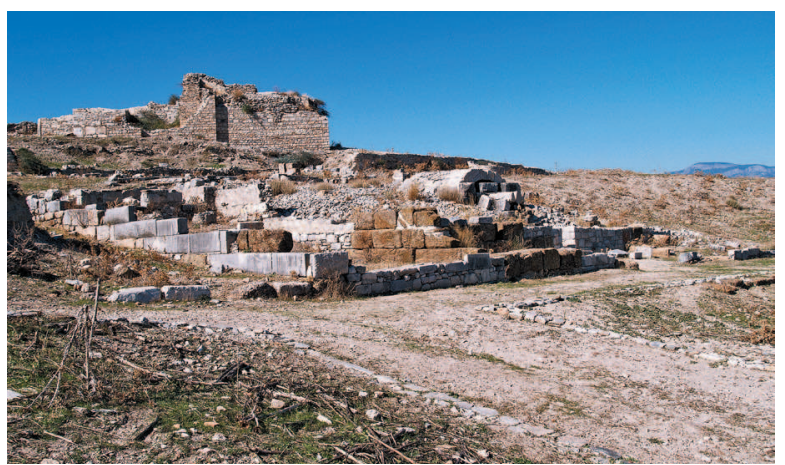

Fig. 4 : Heroon I. View from SE. Current state of preservation (photo author 10/2011).

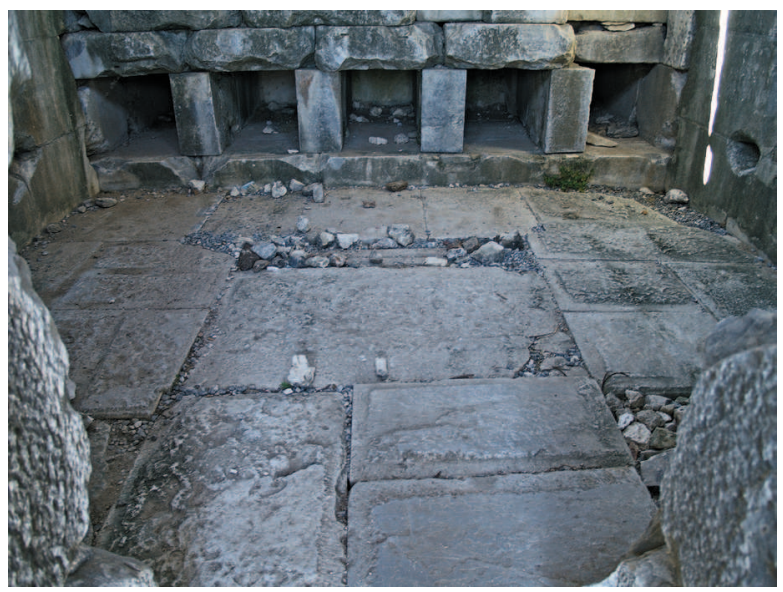

Fig. 5 : Heroon I. Chamber with central cavern (now sealed) in paving and loculi in western wall. Current state of preservation (photo author 10/2011). 


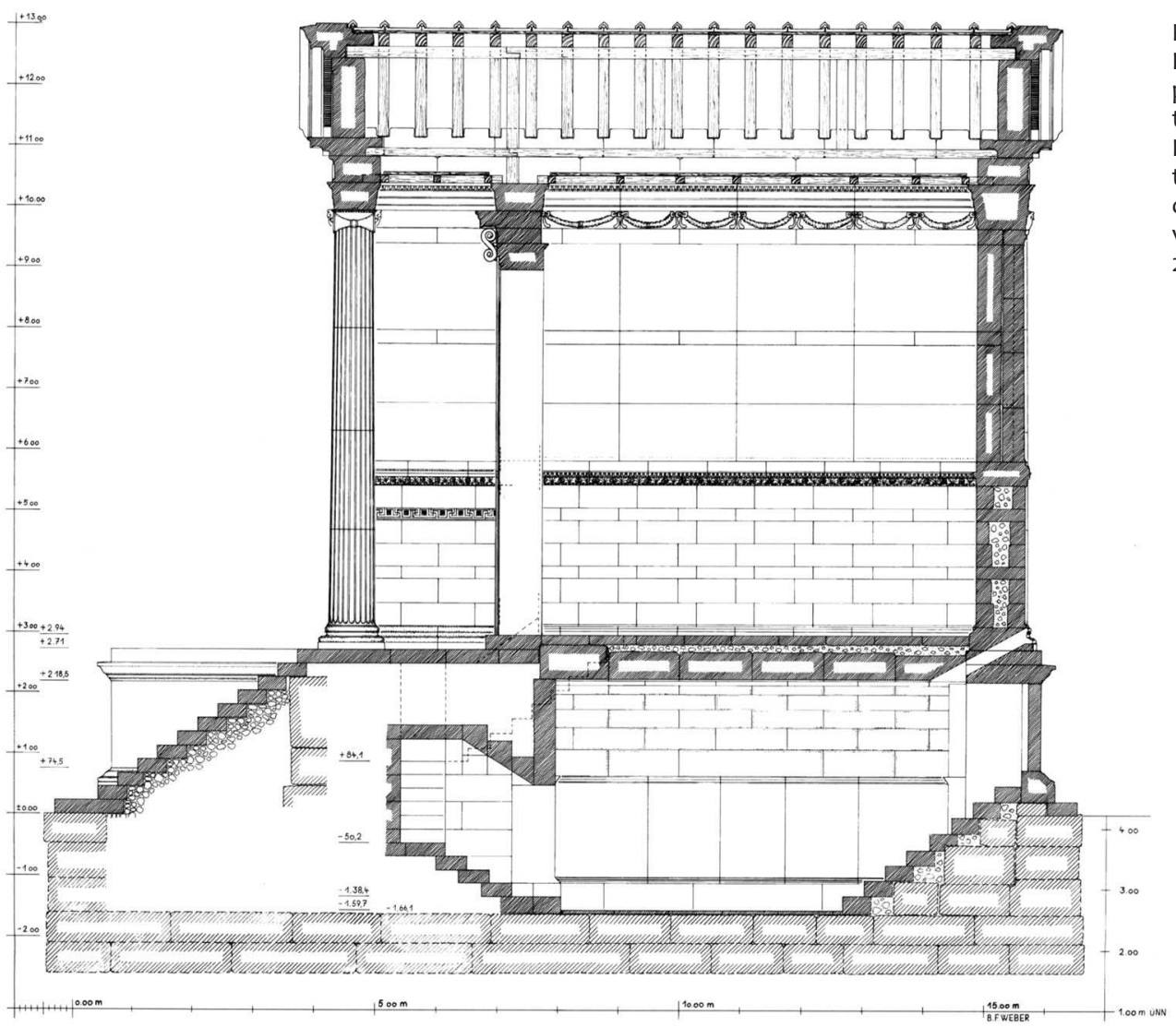

Fig. 6 :

Heroon II. Roman

phase with podium temple on top of the

Hellenistic chamber

tomb. Reconstruction

of longitudinal section

view to $\mathrm{E}$ (from Weber

2004, 69 fig. 59).

Dionysos ${ }^{6}$, and that of the city districts north of Dionysos, on the Kale Tepe (Theatre Hill) and the Humei Tepe, defined by the Delphinion-insula7 .

Heroon I consists of a tumulus of pebble stones, c. $15 \mathrm{~m}$ in diameter, covering a vaulted dromos and chamber, made of marble ashlar blocks. The chamber has a central sunken cavern of square form, covered by a slab. Five additional loculi are integrated into its back wall, signalling a multiple burial. The tumulus is surrounded by an open-court with a row of chambers to the lower eastern street, where the entrance was also located. The masonry as well as few finds speak for a Hellenistic date of the grave, which still awaits a proper investigation ${ }^{8}$.

\section{Heroon II (figs. 6-8)}

Heroon II was situated in the extrem Northwest of the city, north of the so-called West Market, on a small hill above the sea. It lies close to the city-wall, which surrounds it on three sides. The vaulted grave chamber was originally approachable from the south and may date to the Hellenistic period. In the time of Trajan or Hadrian, this entrance was closed and a templum in antis in lonic order was built on top, this time oriented to the north. This podium temple, decorated with a frieze of Erotes, had a staircase in the northeast corner of the cella, leading down into the grave chamber?.

6 Weber 2007,353 . The strip of shorter insulae continues also east of the agora, directly south of the Delphinion. There the baths and the palaestra of Capito cover the smaller insula plus the street in the South, extending $40 \mathrm{~m}$ from North to South: Kleiner 1968, 91-97 figs. 63, 65-68; Weber 2004a, 148.

7 Weber 2004a, 145-150 fig. 87; Herda 2005, 272-285 figs. 25, 29-30. 8 B.F. Weber announced the final publication of his researches on Heroon I, conducted from the 1980's until his death in 2005, as volume $\mathbf{l} .11$ of the Milet-series in his posthumously published article on the city map (Weber 2007,353 , n. 107). It remains open, if and

when this publication will appear. The loculi were already robbed when excavated, but in the central cavern in the floor were found several bones, a well preserved skull, a silver ring, a golden sheet, glas paste and a bone plaque with an Ionic capital scratched in (part of a furniture, e.g. a kline ?): Schörner 2007, $237 \mathrm{f}$. These finds may belong to the original burial of Heroon I and were put here when the chamber was additionally furnished with the loculi.

9 Kleiner 1968, 131 f. fig. 91; Cormack 2004, 39, 243 f. figs. 117-119; Köster 2004, 85-98 figs 13 f., pls. 49-58, 59.1-4, 143, 144.1; Weber 2004a, 3-100, 153-156 figs. 56-73, pls. 1-25; Schörner 2007, 253 f. A26 


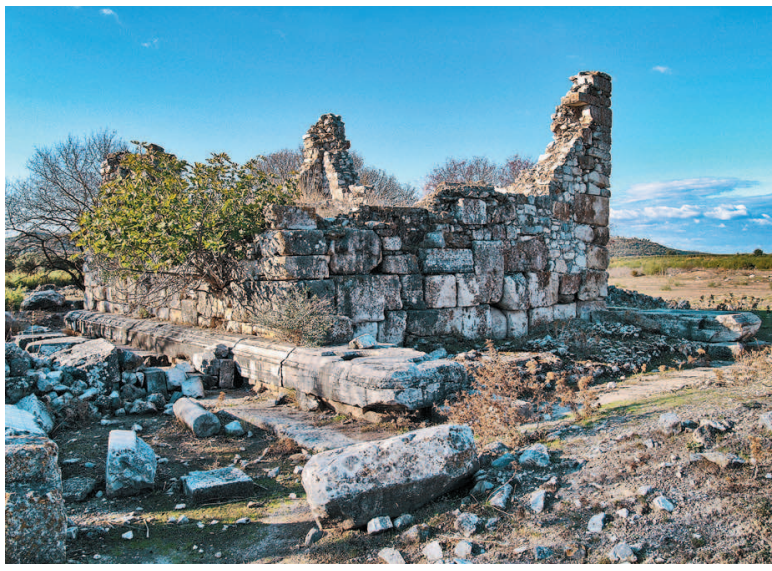

Fig. 7 : Heroon II. View from NE with marble foot profile of Roman podium front overbuilt by a medieval tower. Current state of preservation (photo author 10/2011).

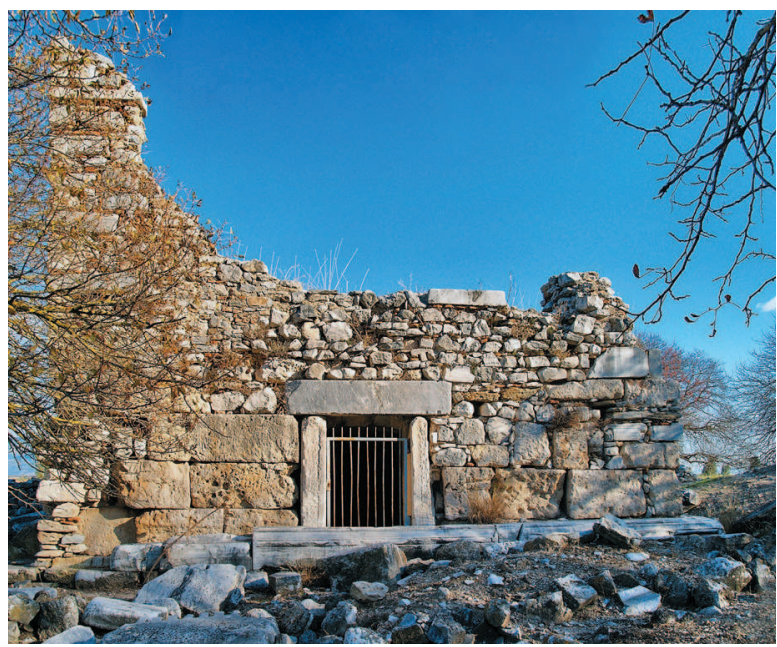

Fig. 8 : Heroon II. View from S with entrance to Hellenistic chamber tomb. Current state of preservation (photo author 10/2011).

\section{Heroon III (figs. 9-10)}

Heroon III is, like Heroon I, integrated in the streetinsula-grid. The peristyl-building fills exactly one insula of 28.60 by $50.27 \mathrm{~m}^{10}$. In the court stands a square-shaped central building with an entrance to the North and West, including a girlandsarcophagus on a high altar-like podium. The style of the architectural ornamentation as well as the stratigraphy date the building complex to the

figs. 149-154. For the Erotes-frieze see now Bol/Weber 2011; von Mangoldt 2012, 360-363 ("B 192. Milet III") pls. $139 \mathrm{f}$.

10 Weber 2004a, 145-150 fig. 87; Weber 2004b, 231-234, fig. 2; Herda/ Sauter 2009, 84 f., fig. 9. beginning $3^{\text {rd }}$ century AD. Fragments of a second sarcophagus speak for a secondary burial in the central cella ${ }^{11}$.

There are commonalities with all three Heroa: We do not know for whom they were built as there are missing significant inscriptions found in them, except from the grave stele of Antigona in Heroon I (fig. 11, see below). The grave epigram of a certain Aristeas, son of Aristeas, who was honoured by the Milesian demos in the late $1^{\text {st }}$ century $B C$ with the manufacture of golden kolossoi (cult statuettes/ 'Voodoo Dolls'/magic images)'12 and a grave within his hometown, was found reused in the Late Roman city-wall and cannot be attributed to any of the known intramural graves in Miletos ${ }^{13}$.

At least the dating and type give some clue for Heroon I, which is, according to Hans von Mangoldt, a typical Macedonian chamber tomb of the late $4^{\text {th }}$ or early $3^{\text {rd }}$ century $\mathrm{BC}{ }^{14}$. Gerhard Kleiner was right when he supposed in 1968, that the grave was related to the Macedonian occupation after the conquest of Miletus by Alexander the Great in 334/33 BC: Convincingly, he located the fortress ( $\varphi$ poúpiov), the Persian satrap Tissaphernes had

11 Kleiner 1968, 132-134, figs. 100-102; Weber 2004a, 101-150, 153-156 figs. 79-81, pls. 26-48; Schörner 2007, 258 f. A29 figs. 168-173.

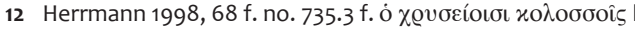

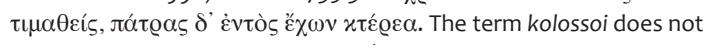
mean 'colossi', 'large statues' here (so Herrmann 1998, 68 f., who translates: “der durch goldene Kolosse geehrt wurde”), but small figurines, used as cult statues or 'Voodoo Dolls', where the soul of the dead hero (or an evil daemon) could settle during the rituals, e.g. a theoxenia or a purificatory magic. Cf. the famous sacred law from Kyrene: Burkert 1984, 69 with n. 69; Faraone 1992, 82-84; Rhodes/ Osborne 2003, 494-505, no. 97 II. B 111-121: two small figurines, a male and a female, made of wood or clay and named kolosos, first recieve "hospitality and a portion from everthing" (ن்

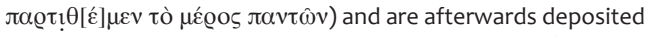
in an "unworked wood", together with the offerings ( $\phi \varepsilon ́ \varrho o v \tau \alpha$

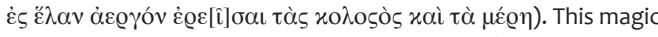

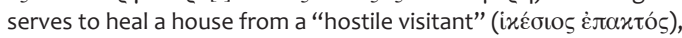
the bad spirit of a dead person; cf. Ogden 2002, 163 f. no. 124; Rhodes/Osborne 2003, 505 on $\S 18$. Also, in the oath of the founders of Kyrene, a figurine, labeled kolosos and made of wax, is burnt: Meiggs/Lewis 1969, 59, no. 5 Il. 44 f.; Burkert 1984, 68 with n. 29. On kolossoi as Voodoo Dolls/magic images see: Ogden 2002, 245-260. 13 Cf. Herrmann 1998, 68 f. in his commentary: "aber die Zuweisung einer der drei aufgedeckten derartigen Anlagen (...) an ihn wird kaum möglich sein"; see also Herrmann 1995, 194. 14 von Mangoldt 2012, 357-359 ("B 190. Milet I"), pls. 138.6-8. The original location of the $3^{\text {rd }} / 2^{\text {nd }}$ century $B C$ amphiglyphic grave stele of Antigona, daughter of Pamphilos (fig. 11), which was found in the area of Heroon I (Herrmann 1998, 5 no. 421), is uncertain: Graeve 1986, 8 f.; Schörner 2007, 237 figs. 93 f.; but to me its affiliation to Heroon I seems highly reasonable. I will refer to this matter in a separate publication; see also below. 


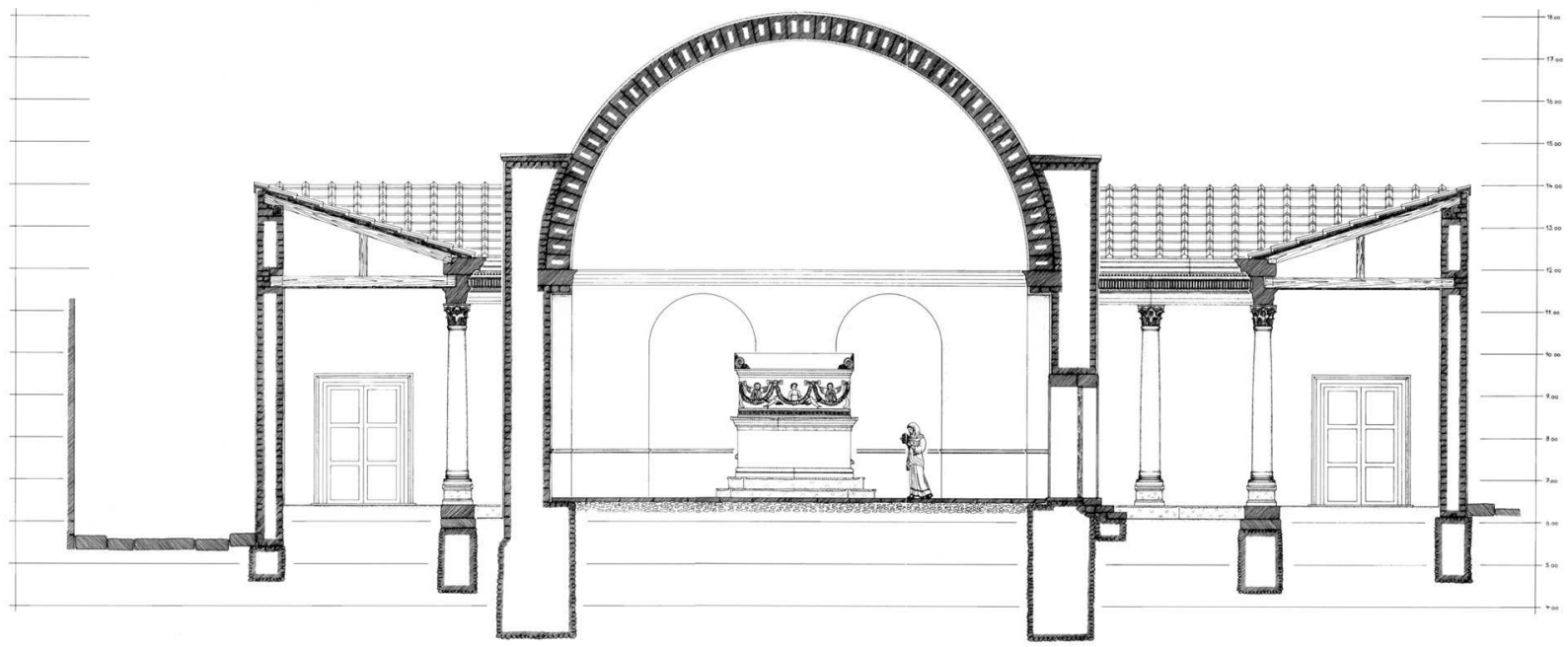

Fig. 9: Heroon III. Reconstruction of E-W cross-section with sarcophagus in the central vaulted chamber (from Weber 2004, fig. 80).

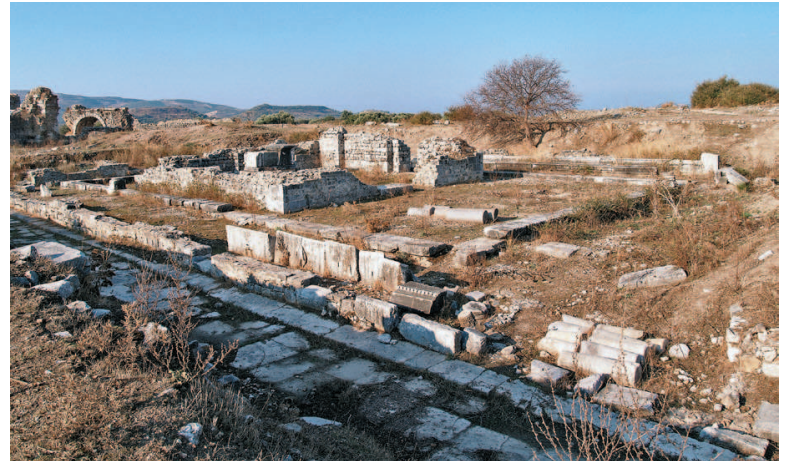

Fig. 10 : Heroon III. View from NE. Current state of preservation (photo author 10/2011).

built in Miletos in 412, on the Theatre Hill, protecting the Lion and Theatre Harbours, seat of the Persian fleet. In consequence, Kleiner equated this fortress

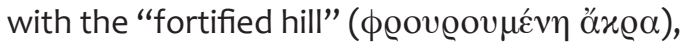
Asandros, installed by Alexander as satrap of Karia c. 324/23 BC, held when he was eponymous aisymnetes of the city in $313 / 12 B C$. The strategical importance of the site is still manifest in todays Byzantine-Turkish castle, which also supplied the name Palatia-Balat for medieval and modern Miletos. Taking into consideration the alledged proximity between fortress and Heroon I, Kleiner finally attributed the grave to one of the Macedonian phrourarchs ${ }^{15}$.

15 Thucydides 8.84-85 (Tissaphernes' ф@oú @ıov); Diodorus 18.3.1 (Asandros as satrap); cf. Marcellesi 2004, 76-81. Asandros as eponymous: cf. A. Rehm in Kawerau/Rehm 1914, 258, no. 122.II 101

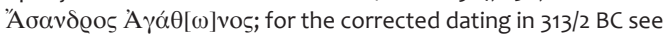
Herrmann 1997, 166 on nos. 122 and 123; for Asandros see also Badian
Looking for a candidate ${ }^{16}$, Asandros is hardly a hot one: He had ruled Karia autocratically and when in 312 he was disposed by Antigonos Monophthalmos, Miletos celebrated the Antigonid as 'liberator', who re-installed democracy ${ }^{17}$. Actually it was not Antigonos, but his two generals, Medios and Dokimos, who freed the city. While Medios attacked Asandros and his forces by sea, Dokimos did so by land. He invaded the city, "summoned the citizens to freedom and after taking by storm the fortified hill ( $\phi \varrho o v \varrho o v \mu \varepsilon ́ v \eta \not \alpha x \varrho \alpha)$, restored the constitution to autonomy"18. In the eyes of the Milesians this deed was definitely worth an intramural hero cult, and more exactly: a founder cult. One only has to think of Spartan general

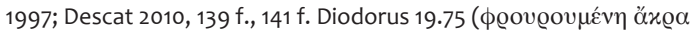
of Asandros); cf. Kleiner 1968, 17 f., 27, 129.

16 Another (less probable) candidate could be Philoxenos, who was the first Macedonian satrap of Karia after the death of the last Hecatomnid, Ada, daughter of Maussollos. Philoxenos immediately preceeded Asandros, but the existing sources do not mention his presence in Miletos: Aristotle, Oikonomia 2.31; for Philoxenos see now Descat 2010, 139 f., 143. The strategically important harbour town changed its owner more often: In $302 \mathrm{BC}$ it came under the control of Lysimachos, in 295/94 Demetrios Poliorketes was eponymous. Antigonids, Seleukids and Ptolemies, all struggled for Karia in the first quarter of the $3^{\text {rd }}$ century $\mathrm{BC}$, a lot of opportunities for a Macedonian to die in Miletos; cf. Kleiner 1968, 17-19; Marcellesi 2004, $72-88$

17 See the prescript of the second preserved eponymic list of Miletos, starting with the year of liberation by Antigonos, A. Rehm in: Kawerau/Rehm 1914, 241 f., 259 f., no. 123.1-4 غ̇лi toútov iं

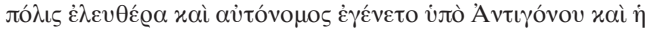

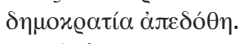

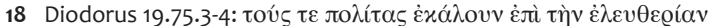

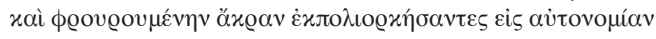

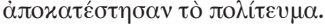




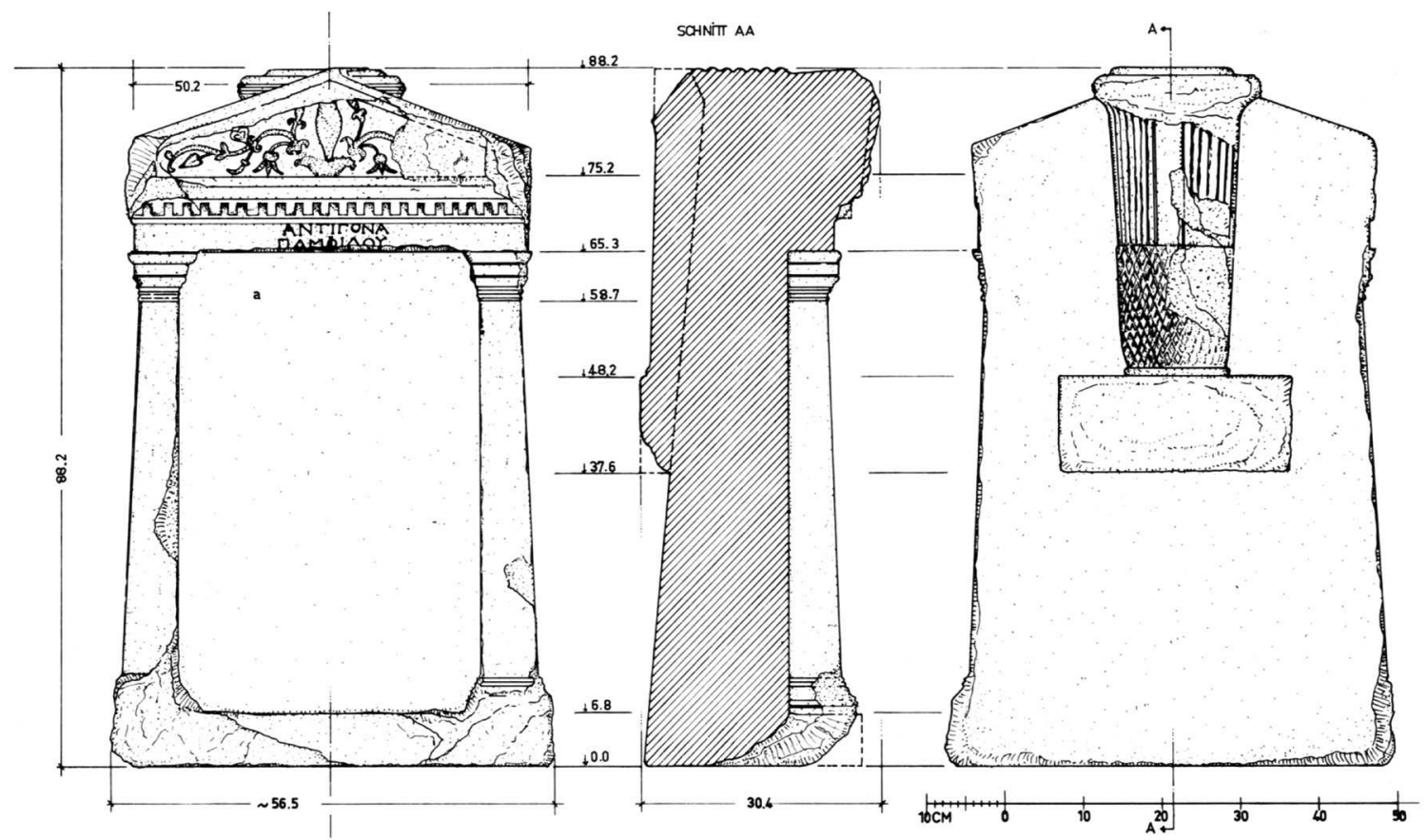

Fig. 11 : Amphiglyphic grave stele of Antigona, daughter of Pamphilos, from Heroon I (heroon of Dokimos?), $3^{\text {rd }} / 2^{\text {nd }}$ century BC (sketch W. Müller-Wiener, in Graeve 1986, 9 fig. 1).

Brasidas, who had conquered Athenian Amphipolis. When he in $422 \mathrm{BC}$ died in a battle where he successfully repelled the counter attack, he got a founder cult in the agora ${ }^{19}$. The alledged founder cult of Dokimos in Heroon I, close to the castle he had conquered, finds another strong argument in the fact that the ancient name of the Lion Harbour, which is commanded by castle and grave, is 'Harbour of Dokimos'. Mid-1 st $^{\text {st }}$ century AD love novelist Chariton of Aphrodisias has his heroine Kallirhoë in late $5^{\text {th }}$ century BC (anachronistically)

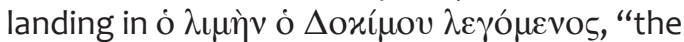
harbour called that of Dokimos". The whole Milesian people is at present, cheering. No other harbour than the Lion Harbour comes into consideration for such a representative event. The circle of arguments is closed by the observation that Kallirhoë's father, the famous Syracusan general Hermokrates, who had repelled Athens' attack on his hometown in $413 \mathrm{BC}$, in 411 conquered the very castle of Tissaphernes above the Lion Harbour, Dokimos one hundred years later should also take ${ }^{20}$.

19 Thucydides 5.11; see below $\S \mathrm{V}$.

20 Thucydides 8.84.5; Chariton, Chaireas and Kallirhoë 3.2.10-17; cf. Jones 1992, 101 (Lion Harbour is Harbour of Dokimos); on the Lion Harbour and Heroon I as heroon of Dokimos see A. Herda in: Brückner et al. forthcoming, §3.1.
Another detail supports our reconstruction: if we assume Heroon I to be erected for the Macedonian general Dokimos, why do we find not only a central burial in the floor of the chamber, but also five loculi in its back wall (fig. 5)? This clearly hints at a multiple burial, typical for a family grave $^{21}$. Either Heroon I was from the beginning planned as family grave, or there was a single grave in the tumulus chamber, later transformed into a multiple burial by adding the loculi in the chamber and the rooms around the tumulus. In regard to the archaeological and prosopographical evidence, the latter solution seems the most likely to me. The existence of descendants of Dokimos, using Heroon I as their family grave, can be backed by the observation that several persons of this name held the office of eponymous aisymnetes in 69/68, $55 / 54$ and 54/53 BC, suggesting the high social rank of his family still in Late Hellenistic Miletos, when the grave saw substantial rebuilding. Another, $3^{\text {rd }} / 2^{\text {nd }}$ century $B C$ family member will have been Antigona, whose exceptional amphiglyphic grave stele was found in Heroon I (fig. 11). Her name, new in Miletos, is clearly a Macedonian dynastic name and refers to Antigonos, the lord of her assumed

21 Kader 1995, 209-211; Berns 2003, 16 f. 
ancestor Dokimos. Similarly does the special type of her grave stele hint at Macedonia²2.

Heroon II may have been another intramural 'Macedonian' chamber tomb in its first phase ${ }^{23}$. The Roman temple on top can signal a transformation into a sanctuary, but again we have no clear clue for its function. It may also have been still an intramural heroon in its second usage ${ }^{24}$. At least its location on top of a small hill only $10 \mathrm{~m}$ north of the Hellenistic 'West Market' may give a hint at its designation: the West Market is actually not a market but a double xystos (roofed race course of one stadium length) and as such part of the largest gymnasium complex in Miletos, most probably the gymnasium of the neoi, the 'new' citizens. Located west of the late Classical stadium, it was enlarged by Eumenes II of Pergamon before 167 BC, presumably by donating the xystos ${ }^{25}$. Because of this spatial

\footnotetext{
22 On the stele see above n. 14. R. Posamentir points me to the fact that the floral decoration of the pediment resembles that of Macedonian grave reliefs, e.g. in the large tumulus of Vergina. He prefers to date the stele rather to the $3^{\text {rd }}$ than to the $2^{\text {nd }}$ century $B C$ (personal communication, 30.12.2012). For Antigona's family see

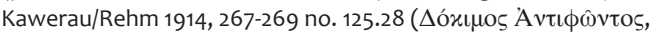

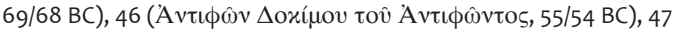

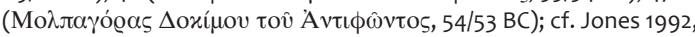
$95 \mathrm{f}$. The rooms grouped around the tumulus, one of them a dining room with a floor mosaique, date to the late $2^{\text {nd }}$ or early $1^{\text {st }}$ century BC: Kader 1999, 210. They could have been part of a re-arrangement of the older burial place in the time of Dokimos or his father Antiphon. For Antigona's stele see above n. 14. For the diffusion of the names Antigonos, Antigona, Antigone especially in Macedonia compare the occurances in the different volumes of LGPN: they are most frequent in vol. IV (Macedonia, Thrace, Northern Regions of the Black Sea)
}

23 See now on the construction and dating of the vaulted grave chamber: von Mangoldt 2012, 360-363 (“B 192. Milet III”) pls. $139 \mathrm{f}$ 24 Weber 2004a, 154 misses an altar as well as a cult statue wherefore he favours a function as grave. But graves often have altars, too, where heroic honours could be payed to the deceased, besides the regular libations into the ground (choai). They included dining at the grave: Burkert 2011a, $296 \mathrm{f}$. For that one only has to think of the countless round altars and trapezai in the Hellenistic necropoleis of Kos, Rhodes, the Rhodian peraia and the Knidia, sometimes combined with exedrai with benches for seating: Berges 1986 and 1996; for Miletos see for example the round altar and exedra in the necropolis south of the Sacred Gate: Forbeck 2002, 99-103 figs. 6-13 (she assumes the exedra to be originally a honorary monument and only secondarily used as grave monument by adding a round altar, reworked into an urn).

25 On the Eumenes II-gymnasium: Kleiner 1968, 89-91; Schaaf 1992, 62-72; Bringmann/von Steuben 1995, 346-349 no. 284 figs. 140-145. It is mentioned in the honorary decree for the Milesian citizen Eirenias of c. 167/6-164 BC: W. Günther in: Herrmann et al. 2006, 2022 no. 1039.6-8, where Eumenes II donated 160.000 medimnoi of grain (c. 6.000-7.000 t) as well as "timber in a sufficient amount" for the construction work. The timber was especially important when we understand the double xystos of the 'West Market' as part of the building program of Eumenes II: the two stadium-long halls required a large amount of timber for the roof construction. Additionally, its architectural details, especially the Doric columns which are facetted in their lower part were already recognized as being close closeness, the owner of Heroon II is likely to be somehow connected to the gymnasium of the neoi. So, Antenor, son of Xenares, a Milesian pankration victor at the $108^{\text {th }}$ Olympic Games of 308 BC, who died ca. $250 \mathrm{BC}$, was honoured by the polis with an intramural grave for him and his progenies "in the middle of the gymnasium of the neoi". The position of his heroon is mentioned in an inscription of one of his descendants of the early $1^{\text {st }}$ century AD, a certain Eudemos, son of Leon. He proudly lists his ancestors, leading back to Antenor ${ }^{26}$. May Heroon II be the grave of Antenor and his family, or of another famous Milesian sportsman?

Heroon III is clearly a Roman intramural heroon. But the name of its owner is unknown. The only inscription found is the dedication of an altar to the "Goddesses of Good Hope" ('E $\lambda \pi \tau^{\prime} \delta \varepsilon \varsigma$ A $\left.\gamma \alpha \theta \alpha{ }^{\prime}\right)$, dating to around $200 A D^{27}$. They also had a cult in Didyma at the same time. Perhaps their Milesian cult was practised in one of the rooms in the northern or southern part of the insula-size building ${ }^{28}$. The preserved structures of Hellenistic and Classical times under Heroon III, including marble architecture and wall paintings with griffons and a tripod, as well as high amounts of tableware, suggests a cultic function, perhaps as a club-house of a religious association for Apollo as well as some other gods. This club-house had then been tranformed into a heroon in the second century $A D^{29}$.

to Pergamenian architecture; Gerkan 1925, 103 fig. 52, p. 105; see Brückner et al. forthcoming, § 4.4 with n. 219 .

At least in the $1^{\text {st }}$ century BC, Miletos had three Gymnasia, one for the paides, one for the epheboi and the neoi, and one for the citizens: Herrmann 1994, 218; Herda 2006a, $92 \mathrm{f}$. As the status/age-class of the neoi was introduced in the Archaic period (cf. Herda 2006a, 92-96 and 2011, 63 n. 37), we have to assume a gymnasium of the neoi from at least late Archaic times on. Therefore Eumenes II did not built the gymnasium from the start, but expanded its building facilities. The Eumenes-gymnasium is to be located west of the stadium, because the Milesian honorary decree for Eumenes (Herrmann 1997, $98 \mathrm{f} ., 210$ no. 307, pl. 22.2) was written on the anta of the so-called Stadiontor, which stood west of the stadium: Günther ibid. 22. On the gymnasium of the Neoi as being the "Great Gymnasium": see below n. 60.

26 Inscription from Didyma: Rehm/Harder 1958, 183-185 no.

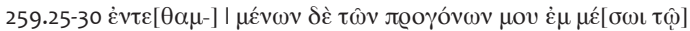

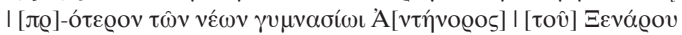

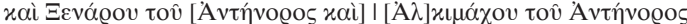

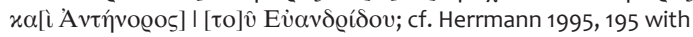
n. 32; Habicht 1995, 91 with n. 19; Schörner 2007, 75, 114, 271 f. B 15. Antenor won the pankration in Ol. 118: Eusebios, Chronical I 205-207;

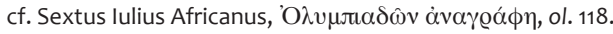

27 Weber 2004a, 120 f. fig. 78.

$28 \mathrm{Herda} / S a u t e r$ 2009, 92. On their cult in Didyma see Weber 2008 (foundation-oracle on an altar of ca. $200 \mathrm{AD}$, wrongly attributed to the Horai, see Herda/Sauter 2009, 92 n. 236).

29 Herda/Sauter 2009, 86 with n. 199, pp. 93-94; see below § IX. 


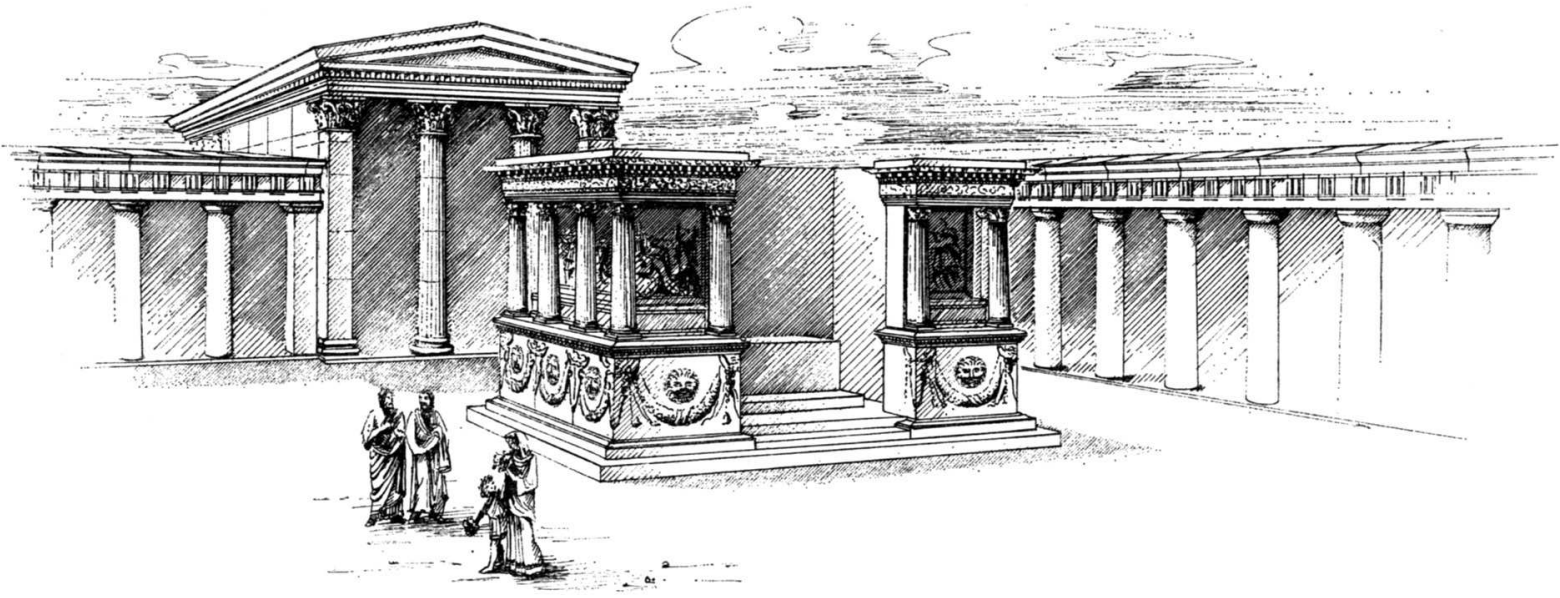

Fig. 12 : Reconstruction of the early Imperial altar for Artemis Boulaia, Apollo Didymeus, Zeus Boulaios, and Augustus and Livia(?) (so-called Ehrengrab) in the courtyard of the Hellenistic bouleuterion. View from W (sketch W. Kunz in Tuchelt 1975, 138 fig. 15).

\section{The 'Ehrengrab' in the courtyard of the Hellenistic bouleuterion: an altar for Apollo Didymeus, Artemis Boulaia and Zeus Boulaios, as well as for Livia and Augustus?}

Before I finally move to Thales, I should also mention a structure in the inner court (peristyle) of the Hellenistic bouleuterion. It is a square shaped structure of 7 to $9 \mathrm{~m}$ decorated with a girland-frieze with bull skulls and lion heads as well as a second frieze with mythological scenes, most probably of Apollo, Leto and Artemis as well as some other local gods (figs. 12-14). The style of the sculptures as well as the architectural ornaments suggest a dating in the early $1^{\text {st }}$ century AD ${ }^{30}$. Because of fragments of sarcophagi found close by, the monument was interpreted as 'Ehrengrab', heroon ${ }^{31}$. Louis Robert and Peter Herrmann additionally took into account decrees of Augustean times on the walls of the bouleuterion peristyle, mentioning the Milesian citizens Gaius Iulius Apollonios and his son Gaius Iulius Epikrates. Both were honoured by the people

30 On the dating of the reliefs see most recently Schollmeyer 2011, $19 \mathrm{f}$. On the dating of the architectural ornaments in Augustan times see Köster 2004, 15 n. 108; p. 29 (first third of $1^{\text {st }}$ century BC). 31 Knackfuß 1908, 49-55, 63-66 figs. 79-88, pls. 13-14, 16-18; Cormack 2004, 150 f., 245 f.; Köster 2004, 15-31 figs. 2-5, pls. 8-13, 14.1-4, 138.68; Schörner 2007, 177-181 figs. 198-199; Schollmeyer 2011.

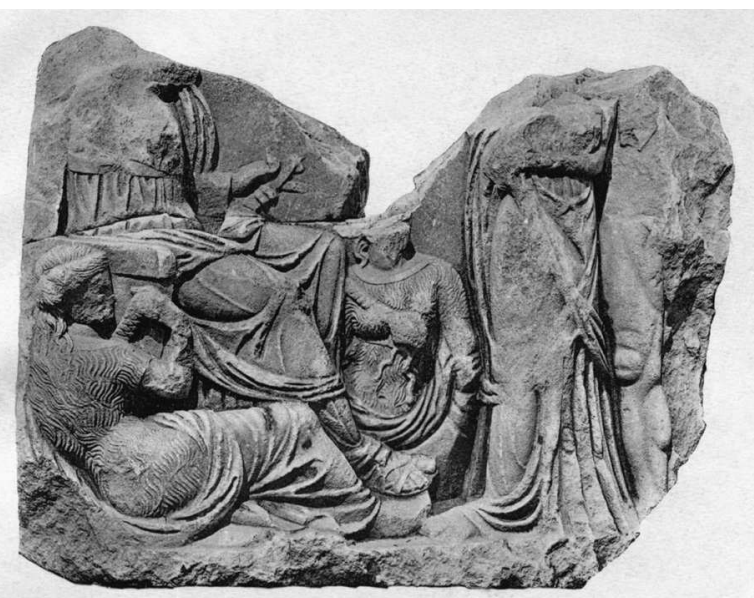

Fig. 13 : Altar in the courtyard of the Hellenistic bouleuterion. Relief with Leto (left, seated on throne), two nymphs (of the Mykale Mountain?), and Artemis and Apollo standing to right. Early $1^{\text {st }}$ century AD. Istanbul, Archaeological Museum Inv. 2019 (photo Knackfuß 1908 pl. 17, 1).

of Miletos as "heroes" 32 . Following this line, the 'Ehrengrab' has in recent years been interpreted as grave of a Milesian citizen who had been venerated

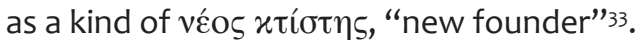

But already in 1975, Klaus Tuchelt stressed that the fragments of sarcophagi, found in the peristyle,

32 L. Robert, Hellenica 7, 1949, 96 (= OMS IV 103); Günther 1989, 174 f.; Herrmann 1994, 229-234 and 1995, 197 with n. 39; Herrmann 1997, 156 nos. 6-7 (no. 7 dated to 6/5 BC), 159 no. 15; Herda 2006a, 296 n. 2111. See also the honorary decrees for C. Iulius Epikrates, Herrmann et al. 2006, 82-85 nos. 1130-1131.

33 Cormack 2004, 150 f.; Schörner 2007, 181; Schollmeyer 2011, 10; R. Bol in: Bol 2011, 10 with n. 120. 
should not be attributed to the 'Ehrengrab'. It is even uncertain if they formed an original part of the bouleuterion's inventory. Instead it is reasonable that they were brought there from outside at a later date, probably in the early Byzantine period 34 . Tuchelt has also convincingly argued for a roofless, hypæthral construction of the 'Ehrengrab'. According to him, this strongly speaks for the interpretation as a monumental altar of a type, common in Ionia since the late Archaic period 35 . Taking into account inscriptions from the bouleuterion, honouring a priest of the Milesian cult of emperor Augustus, the very Gaius lulius Epikrates, he proposed to identify the 'Ehrengrab' as an Ara Augusti, an altar for the living Augustus, comparing it to the famous predecessor, the Ara Pacis Augusti, in Rome, dedicated not to the living Augustus but to the peace he brought, on $1^{\text {st }}$ of September $9 \mathrm{BC}^{36}$.

While Tuchelt's hypæthral reconstruction of the building and its interpretation as an altar is absolutely convincing 37 , his attribution to the cult of Augustus is not so compelling: There are no inscriptions from the bouleuterion, which directly testify to the cult of Augustus within the bouleuterion ${ }^{38}$. This lack of evidence led Tuchelt

34 Cf. Tuchelt 1975, 97, 129 hints at $3^{\text {rd }}$ century AD grave inscriptions found in the courtyard, which were brought there "erst in nachantiker Zeit": C. Fredrich in: Knackfuß 1908, 122 nos. 28-30. 35 Tuchelt 1975, 128-140 figs. 12-13, 15 Beilage 1-2, pls. 21-30; cf. Köster 2004, 15 n. 108. Against a hypæthral reconstruction: Schörner $2007,179 \mathrm{f}$. The two fragments, Schörner 2007, 180 n. 1562 is claiming for being part of the roof, are too small and were therefore more convincingly attributed to a sarcophagus lid by Knackfuß 1908, 78 f. fig. 88 . Schollmeyer 2011, 20 seems to follow Tuchelt but reprints the wrong reconstruction of Knackfuß (ibid. 21 fig. 4), showing the 'Ehrengrab' with a flat roof.

36 So Tuchelt 1975, 97 f., 136. who deduces from the installation of Herrmann 1997, 156 nos. 4, 6-7 (list of donations inter alia of Gaius Iulius Epikrates for the temple of Augusts) on the inner side of the northern wall of the bouleuterion peristyle (no. 6) that the altar in the peristyle was for Augustus. He argued against C. Fredrich in: Knackfuß 1908, 111 f., who instead located the two inscriptions on the outer northern side of the wall. Fredrich suspected the Sebasteion, mentioned in no. 7.B 18-20, in the area north of the bouleuterion. On the whole argumentation and its critics see Herrmann 1994, 229-234 who at least seems to follow Tuchelt in his conclusion that the Ehrengrab is an Ara Augusti. See also Hermann 1998, 156 on no. 4. The Milesian Sebasteion for Augustus was most probably located in the temple of Apollo in Didyma, where Augustus was synnaos theos, "a god sharing the temple" (with Apollo): Tuchelt 1975, 97 with n. 33; Günther 1989, 175 f.; sceptical: Herrmann 1989, 195 n. 24; indifferent: Herrmann 1998, 156

37 See already Wiegand 1902, 151 fig. 9, and the reconstruction of $\mathrm{H}$. Knackfuß ibid. 154 fig. 10!

38 The "Ehreninschrift für Kaiser Augustus", said to have come from the bouleuterion (C. Fredrich in: Knackfuß 1908, 107 no. 5 fig. to modify his attribution. In 1981 he proposed the altar to be not for Augustus alone, but also for the other gods venerated in the bouleuterion, first of all Apollo Didymeus and Hestia Boulaia, who are mentioned in addition to the Milesian Demos in the dedicatory inscriptions on the propylon and the assembly hall 39 . This assumption makes perfect sense at least in the case of Apollo Didymeus and leads us back to a proposal Theodor Wiegand had already made in 1901, when the 'Ehrengrab' had just been discovered. Before the heroon-theory succeeded and was promoted by the influential publication of Hubert Knackfuß in $1908^{40}$, he came up with the idea of an altar for Artemis Boulaia as a typical "Rathsgöttin"41. Wiegand backed up this idea with the observation that Artemis was, besides Apollo, also depicted three times in the relief frieze of the altar ${ }^{42}$. Strangely, he ommitted the strongest argument

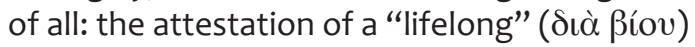
priestess of Artemis Boulaia in a contemporary early Imperial inscription from Miletos ${ }^{43}$. According

101) instead originates from the scenae frons of the Milesian theatre and is a dedicatory inscription for emperor Nero: Herrmann 1998, 156 no. 5. C. Fredrich in: Knackfuß 1908, 103-106 no. 4 ("Liste von Schenkungen und Vermächtnissen"), written on the outer antae of the propylon, was attributed by Fredrich to the Imperial cult, too. Again, this is only a hypothesis: Herrmann 1994, 230 n. 126; Herrmann 1998,156 on no. 5. A small round altar of Augustus was found in the peristyle of the Baths of Capito: A. Rehm in: Herrmann 1997, 110, no. 335 (wrongly identified as basis of an Augustus-statue); cf. Herrmann 1997, 212 no. 335, pl. 23.3. It may have been originating from there, or more probably from the adjacent Delphinion.

39 Tuchelt 1981, 180 Anm. 75; cf. Herrmann 1994, 229 n. 120; Schollmeyer 2011, 20 n. 189. The dedicatory inscription of c. 175-163 $B C$ is placed on the bouleuterion twice (on the epistyle of the assembly hall and the architrave of the propylon): Th. Wiegand in: Knackfuß 1908, 95-99; C. Fredrich in: Knackfuß 1908, 100 nos. 1-2; Herrmann 1997, 155 nos. 1-2; Schollmeyer 2011, $18 \mathrm{f}$.

40 Besides the finds of sarcophagus-fragments, Knackfuß 1908, 78 aduced for his refusal of the altar theory that the 'Ehrengrab' is only of early Roman times, wherefore the altar of the Hellenistic bouleuterion would lack. See also Schörner 2007, 178. But the original altar of the bouleuterion, the Hestia Boulaia, is to be expected within the assembly hall, see already Tuchelt 1975, 129 with $\mathrm{n}$. 163. The altar in the courtyard of the peristyle is therefore a secondary altar. 41 Kekule 1900, 109 f. fig. 2; Wiegand 1901a, 906; Wiegand 1901b, 195; Wiegand 1902, 151 fig. 9, 154 fig. 10 (both reconstructions as hypæthral altar are made by Knackfuß!); mentioned by Schörner 2007, 177 with n. 1537, 178 with n. 1544.

42 Th. Wiegand in: Knackfuß 1908, 87-90, pls. 16.1, 17.1-2, 18.2; Schollmeyer 2011, 21, 23 f. II.1, 3-4, pls. 2a, 3a-b.

43 Honorary inscription for Iulia Artemo, daughter of Antipatros, erected by the boule and the demos of Miletos in the early Roman period: Rehm/Harder 1958, 214 no. 330 (found in Miletos "prope theatrum ad marmoream basim" and copied by Cyriacus of Ancona during his visit in Miletos in 1412, now lost). Rehm commented

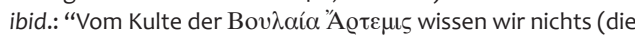

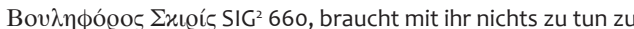




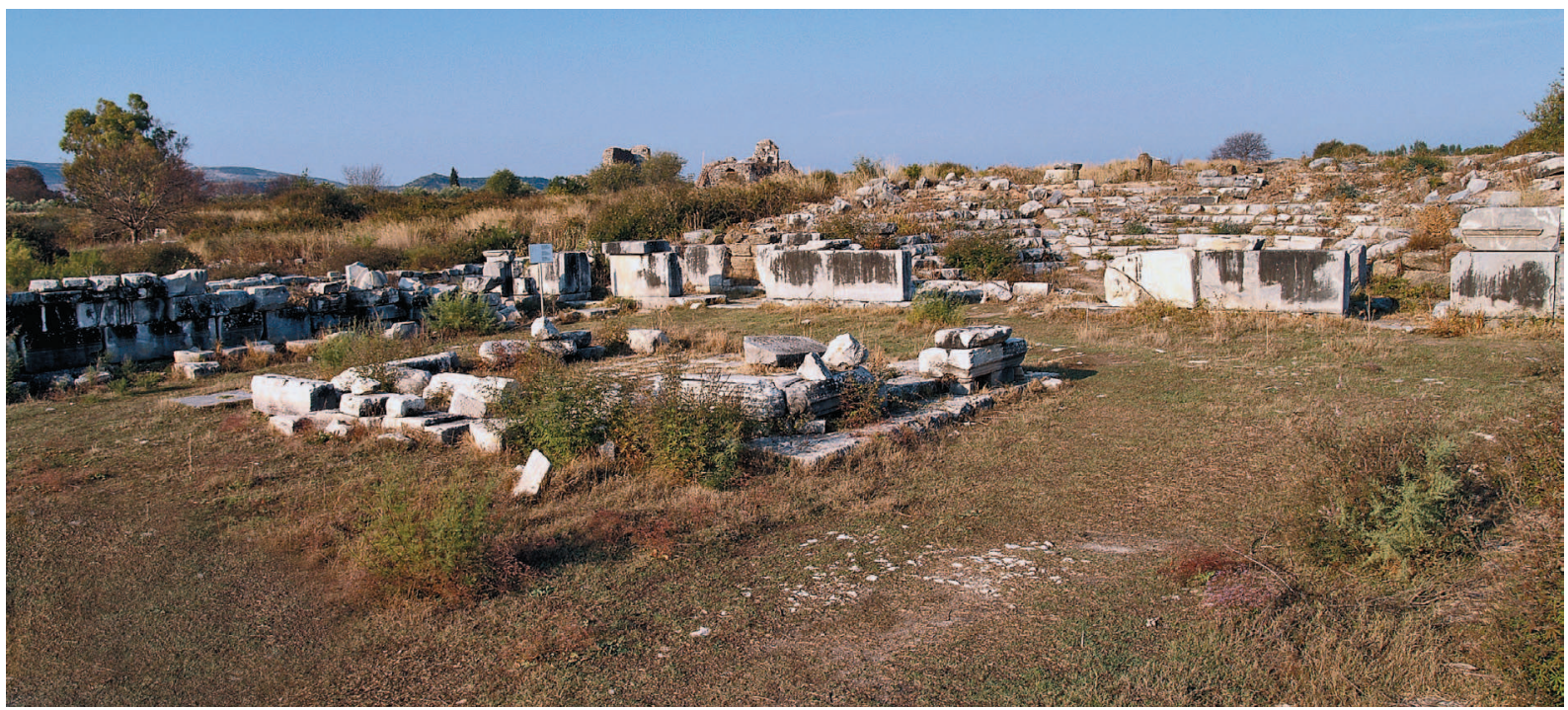

Fig. 14 : Altar in the courtyard of the Hellenistic bouleuterion. View from NE. Current state of preservation (photo author 10/2011).

to the priestess' name, Iulia Artemo, she was a member of the Gaii lulii, the very family, which had close ties to the Roman gens Iulii from the time Epikrates, son of Apollonios, had freed young Cesar in $75 \mathrm{BC}$ from the Cilician pirates ${ }^{44}$. This Epikrates was the father resp. grandfather of Gaius Iulius Apollonios and Gaius Iulius Epikrates, who were honored and designated as "heroes" in the bouleuterion inscriptions mentioned above ${ }^{45}$. lulia (Artemo) is known from another inscription, the dedication of a small round altar, perhaps erected by her and her husband Sextus (Caelius?) for Artemis Boulaia in the bouleuterion. In this dedication Sextus boasts to stem from Timarchos, one of the builders of the bouleuterion more than 250 years ago ${ }^{46}$.

As a third deity honoured at the monumental altar we have to expect Zeus Boulaios, while the hearth-altar of Hestia Boulaia has to be located

haben), er muß aber doch lange vor der Kaiserzeit bestanden haben". The inscription was first published in $\mathrm{BCH} 1,1877,287 \mathrm{f}$ no. 64 and is also cited by Wernicke 1896,1381 . Wiegand may have refered to it in the preliminary report, though he gave no citation. In the final publication (Knackfuß 1908) it is not mentioned at all. 44 Polyaenus 8.23.1; Plutarchus, Caesar 1-2; cf. Günther 1989, 174. 45 On the family see Günther 1989; Herrmann 1994 and 1998, 156; W. Günther in: Herrmann et al. 2006, 82-85. For lulia Artemo's stemma see: Hommel 1976, 327.

46 Hommel 1976; N. Ehrhardt, in: Herrmann et al. 2006, 154 no. 1242 , pl. 25 (dated to the early $2^{\text {nd }}$ century AD, found reused in a Turkish house in Balat-Miletos). within the assembly hall, not outside ${ }^{47}$. Zeus Boulaios is mentioned in two inscriptions of the later $3^{\text {rd }}$ century $\mathrm{BC}$, predating the construction date of the bouleuterion of Timarchos and Herakleides. They therefore refer to an older Classical or early Hellenistic bouleuterion, otherwise unknown ${ }^{48}$. The honorary statue for a certain Lichas was according to its secondary inscription re-erected "at the propylon of Boulaios" of the new bouleuterion ${ }^{49}$.

\footnotetext{
47 See above n. 40 for Hestia Boulaia. The lower part of a clothed female statue, found in the assembly hall by the excavators, was interpreted as cult statue of Hestia: Kleiner 1968, 79; Nawotka 1999, 156. Unfortunately, the torso is not preserved, at least is it not mentioned in Bol 2011. Cult statues of Hestia are rather rare. In the prytaneion at the old agora of Athens (for the location NE of the Acropolis see Herda 2005, 274 f. fig. 26), an agalma of Hestia was shown: Pausanias 1.18.2-4; cf. Miller 1978, 15, 17, 173 f. no. 221. Other statues are mentioned for Paros and Delos: Miller 1978, 15 with n. 25 48 Nawotka $1999,152 \mathrm{f}$. In the mid- $6^{\text {th }}$ century BC, Thales advised the Ionians to build a common bouleuterion in Teos: Herodotus 1.170; cf. $\S$ VII. If this can serve as an indication for a bouleuterion in Miletos already in the mid- $6^{\text {th }}$ century $B C$ is an open question.

49 C. Fredrich in: Knackfuß 1908, 115-117 no. 12a, I. 12: ع̈x

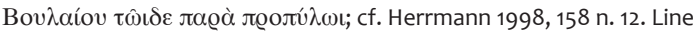
$1-4$ are the original inscription of before c. $220 \mathrm{BC}$, completed in the first half of the $2^{\text {nd }}$ century BC by the epigramm II. 5-16 below. A. Rehm in: Kawerau/Rehm 1914, 246 n. 1 dated the epigram shortly after $200 \mathrm{BC}$, before the construction of the bouleuterion. But this makes no sense, as the propylon mentioned in I. 12 is supposedly that of the new, not the old bouleuterion. The area directly east of the former propylon is at least the place, where the basis was found during excavations. The building inscriptions of c. 175-163 BC therefore deliver a terminus post quem for the Lichas-epigram. For the the paleography: Herrmann 1997, pl. 2.1-2. In the late $1^{\text {st }}$ century BC the basis was re-dedicated for L. Domitius Cn. f. Ahenobarbus, consul in $16 \mathrm{BC}$, this time the inscription was written
} 
This Boulaios is not to be identified with Apollo50, but with Zeus ${ }^{51}$ as becomes clear from another inscription, a psephisma regulating the integration of new citizens from Crete, inscribed in the walls of the sanctuary of Apollo Delphinios in 229/8 BC. It orders sacrifices of the priest, the prytanes and the ones in charge of the protection of the city, to Hestia Boulaia and Zeus Boulaios ${ }^{52}$.

In summary, then: the altar in the bouleuterion court is likely a joined altar of Apollo Didymeus, Artemis Boulaia and Zeus Boulaios. This would fit with the theme of the altar-frieze (fig. 13) and, independently, the situation in Athens where, from the mid- $3^{\text {rd }}$ century $B C$ on, the prytaneis had to sacrifice to Apollo Prostaterios, Artemis Boulaia and the other ancestral gods "for the health and safety of the boule, the Demos, and the children and women". The altar stood in the agora, close to the Tholos and the bouleuterion ${ }^{53}$. In this area was also found the basis of an honorary statue for Augustus' wife Livia, put up by the Athenian Demos and the boule. In the inscription, which dates to the time of Tiberius (14-19 AD), Livia Augusta/Sebaste is assimilated with a goddess whose name is not preserved but who is bearing the epithet Boulaia. It makes most sense, then, to suppose Artemis Boulaia, since her altar stood close by ${ }^{54}$. Taking into account that Augustus was venerated in Eleusis as Zeus Boulaios also, we detect the assimilation of the first lulio-Claudians to the political deities of Athens 55 . We may therefore assume a similar

on the opposite side: C. Fredrich in: Knackfuß 1908, 115-117 no. 12b; Tuchelt 1979, 190 (L 79), pl. 4.2-3.

50 Th. Wiegand in: Knackfuß 1908, 96.

51 Herrmann 1998, 158 in his translation: "(Zeus) Boulaios", refering to A. Rehm in: Kawerau/Rehm 1914, 246 n. 1; cf. also Wiegand 1901b, 196; Knackfuß 1908, 124, index III: "Bovגaîos (Zeus)".

52 A. Rehm in: Kawerau/Rehm 1914, 183 no. 37c, Il. 42-44: tòv

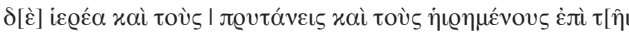

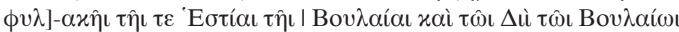

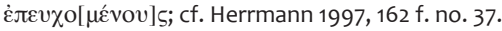

53 Altar: Wycherley 1957, 55 no. 118 (c. 220 BC); sacrifices: Wycherley 1957, 56 f. nos. 119-121; Meritt/Traill 1974, 97-99 no. 89.7-11 (254/3 BC), 108 no. $111.2-7$ (c. 240 BC), $109-111$ no. $115.9-17$ (235/4 BC); and more often; cf. Mikalson 1998, 112 f., 115 f., 181, 194 f., 255, 268, 295. For the Tholos being the prytanikon, where the council of the 50 prytanes hold their office after the reforms of Ephialtes in 462 BC: Herda 2011, 71 f. n. 92.

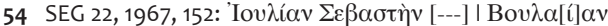

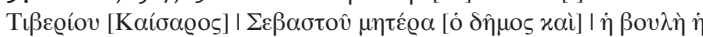

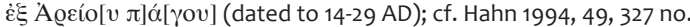
56; Kantiréa 2007, 113 f.; Camia 2011, 198 f.; Geagan 2011, 144, 148 no. H254, p. 294

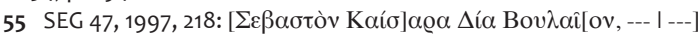
(...); cf. Kantiréa 2007, 114. situation in Miletos: Augustus could have been equated with Zeus Boulaios, and Livia Augustal Sebaste with Artemis Boulaia56. The Milesian altar was then dedicated to the divine tripple (Artemis Boulaia, Zeus Boulaios, Apollo Didymeus) as well as to the Imperial couple.

It has become quite clear now that the 'Ehrengrab' cannot be the heroon of Gaius lulius Apollonios and/or Gaius lulius Epikrates. Where do we have to look for it instead? Peter Herrmann proposed the area directly north of the bouleuterion, which had previously - but without any clear evidence - been identified as Sebasteion for the cult of the Roman Emperors ${ }^{57}$. Also possible is one of the Milesian gymnasia. At least was a honorary statue of the heros $\mathrm{C}$. Iulius Epikrates mentioning his merits as "gymnasiarch of all gymnasia", "restored in the gymnasium" in the mid-1 $1^{\text {st }}$ century $A^{58}$. Which of the three Milesian gymnasia it was, remains open ${ }^{59}$. Maybe we can identify it with the one of the Neoi, which was definitely the most important, and where the heroon of Olympic victor Antenor and his family was already situated, as mentioned above ${ }^{60}$. The placing of heroa in gymnasia is significantly frequent ${ }^{61}$.

But, we should not leave aside the bouleuterion as a potential place of hero cults too hastely. I want to point out an important finding that has escaped the attention of scholars so far:

56 Compare also Thera, where Germanicus was equaled with Zeus Boulaios and Agrippina with Hestia Boulaia: Hahn 1994, 15, 49, 138, 340 no. 134

57 Herrmann 1994, 233 f.; idem in: Herrmann et al. 2006, 85. A small architrave with an inscription, naming lulius Apollonios in the genetive, may have been part of the heroon architecture. Unfortunately its findspot is unknown: Herrmann 1994, 234 f. fig. 3. 58 The statue basis was found SW of the theatre, re-used in the foundation of a Turkish caravansary: Herrmann 1996; P. Herrmann in:

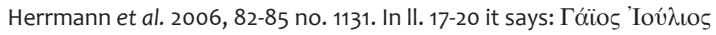

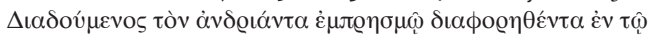

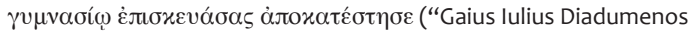
restored the statue which had been destroyed by fire in the gymnasium"). C. Iulius Diadumenos is most probably a descendent of C. Iulius Epikrates.

59 Cf. Herrmann 1994, 28.

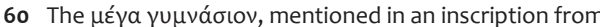
Didyma (A. Rehm in: Rehm/Harder 1958, 114 f. no. 84), besides the Faustineion and the Capitoneion (see Herrmann 1994, 218) is most probably the gymnasium of the Neoi. As the latter two are identifyable (Kleiner 1968, 89-109), the "Great Gymnasion" or gymnasion of the Neoi respectively is the one including the "West Market' (= xystos?) and the stadium; see above with n. 25 . 61 Schörner 2007, 134 f. with other examples in n. 1128, see also ibid. 200. 


\section{The chamber in the eastern corridor of the assembly hall of the bouleuterion: a thesauros or/and a heroon of the builders Timarchos and Herakleides or/ and the heroes Gaius Iulius Apollonios and Gaius Iulius Epikrates?}

At the southern end of the eastern corridor in the assembly hall of the bouleuterion of Miletos is a subterranean chamber (figs. 15-16). Its dimensions are $1.80 \mathrm{~m}$ in length, $1.68 \mathrm{~m}$ in width and $1.59 \mathrm{~m}$ in depth and it is accurately made of large marble slabs. It was closed with $2.00 \mathrm{~m}$ long and $0,35 \mathrm{~m}$ thick slabs, the northern one of which has a hole for lifting it up ${ }^{62}$. The slabs were originally fixed with melted lead and integrated into the pavement of the corridor. Within the chamber were found 10 to 13 skeletons, piled along the northern wall by medieval looters who had approached it from the south end. Some of the skulls were well preserved and showed 'Mongolian' features. The excavators believe the skeletons to be secondarily stored in the chamber by the medieval Turkish looters ${ }^{63}$. In the final publication Hubert Knackfuß interpreted the chamber as thesauros, a built 'treasure-chamber' with a locking system to store large amounts of money and other worthy things, comparing it with such an istallation in Temple B of the Asklepieion of $\mathrm{Kos}^{64}$. One may also compare the so-called thesauros in the agora of Messene, found in 2006 only ${ }^{65}$. Inside this room, the Achaean general Philopoimen may have been locked and poisened 183 BC, as

62 Knackfuß 1908, 34, pls. 1 (stone plan) and 4 (reconstruction of assembly hall with position of chamber and its measures). 63 Knackfuß 1908, 34; Kleiner 1968, 78 f.; Wiegand 1902, 154 added: "Es [the chamber, A.H.] hat im Mittelalter als Bestattungsort für 13 Leichen gedient, deren Schädel mongolischen Typus zeigen”. 64 Knackfuß 1908, 34 fig. 7 (Kos); cf. Kleiner 1968, 78 f. For Kos and comparable installations, which are no 'pour-boxes', as otherwise meant with the term thesauros, see: Kamiski 1991, 133-145; Riethmüller 2005, I 217.

For the spatial closeness of a public thesauros with a bouleuterion see Vitruve, de architectura 5.2.12: Aerarium, carcer, curia foro sunt coniugenda ("Threasure, prison, council hall shall be located together in the agora"); cf. Themelis 2006, 51 and 2010, 122. 65 Themelis 2006, 49-52, pls. 40-42a and 2010, 122 f., pls. 53.4 and 54.2 .

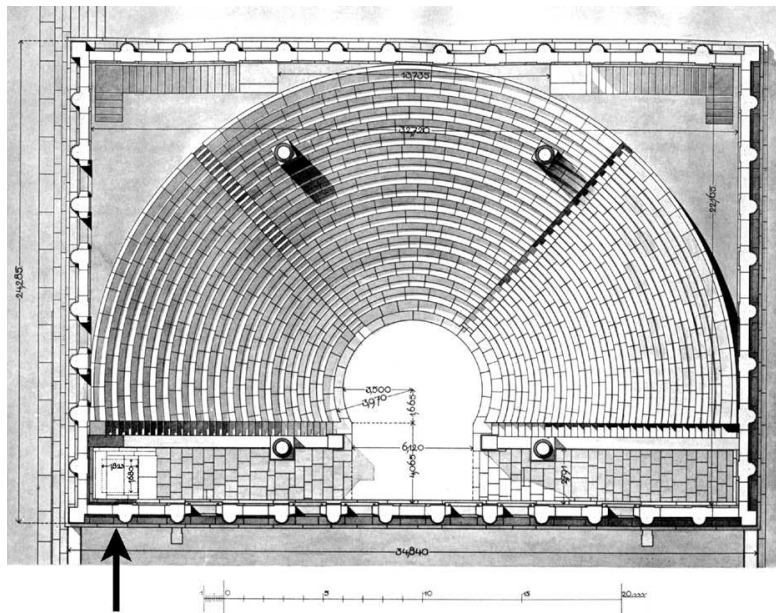

Fig. 15 : Underground chamber (thesauros, later on heroon?) in the eastern corridor of the assembly hall of the Hellenistic bouleuterion. Ground plan of the hall ( $\mathrm{N}$ is to the right) with marked location of chamber in the SE-corner

(from Knackfuß 1908, pl. 4).

we known from Plutarch ${ }^{66}$. It seems as if this subterranean chamber had later served as a heroon of Philopoimen in Messene, since two curse tablets were found in the filling67; they are typical indicators of magic at graves, especially at graves of persons who died a violent death ${ }^{68}$.

\footnotetext{
66 Plutarch, Philopoimen 19-20 explicitly speaks of a "so-called

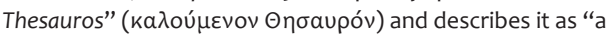
subterranean chamber which admitted neither air nor light from outside and had no door, but was closed by dragging a huge stone in front of it. Here they placed him, and after planting the stone against it, set a guard of armed men round about" (oíx

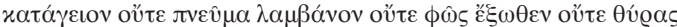

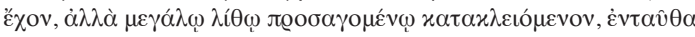

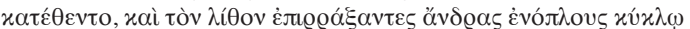

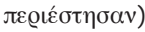

67 Cf. Themelis 2006, $51 \mathrm{f}$. and 2010, $122 \mathrm{f}$. Themelis assumes that the thesauros was left in ruin immediately after the death of Philopoimen, kept as a 'place of superstition and magic' by the Messenians. As the place is located in the middle of the agora, it seems more likely to me that the Messenians installed a kind of hero shrine at the historical spot. It would have been abandoned only when the cult had been of no interest any more or had fallen victim to Christianity. A hint at the point in time of abandonment will give the disturbed filling of the structure, whose finds and dating is not published so far. From Diodorus 29.18, Livy 39.50.9 and Plutarch, Philopoimen 21.3-9 we know that Philopoimen was cremated in Messene (we may assume that this took place close to his place of death, in the agora) and that the urn with the burnt remains was immediately translated by the Achaean League in a procession from Messene to his hometown Megalopolis. There, a mnema and an alta were erected in the agora where he received a hero cult with games: cf. also IG V 2, 432; cf. Schörner 2007, 76, 274 f. fig. 175 (“B 17"). 68 Kurtz/Boardman 1985, $259 \mathrm{f}$. In the case, where a hero's grave does not include his bones or ashes, Rohde 1925, I 163 with n. 2 thought of a magic calling and binding ( $\dot{\alpha} v \alpha \dot{x} \lambda \eta \sigma \iota \varsigma)$ of the hero's
} 


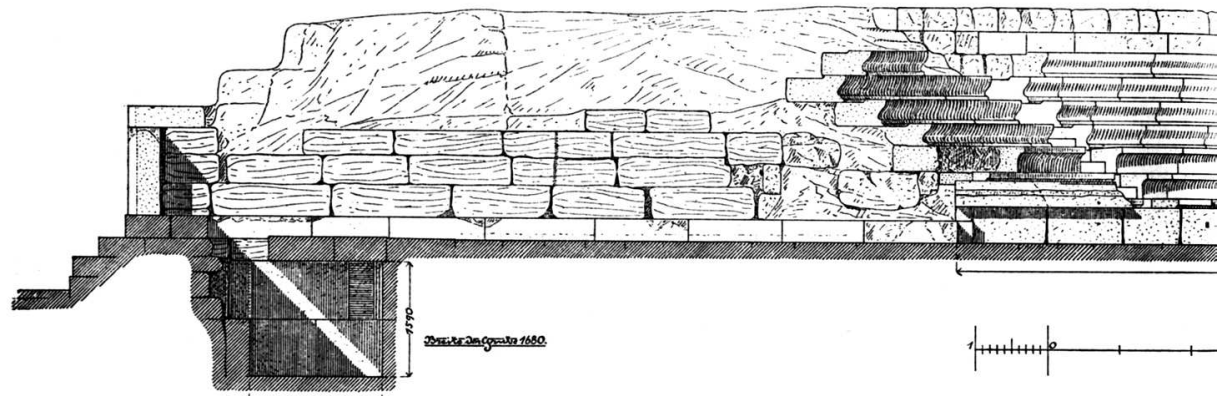

Fig. 16 :

Underground chamber

(thesauros, later on heroon?) in the southern corridor of the assembly hall of the Hellenistic bouleuterion. Section through the south end of the eastern corridor with chamber at left, view from $E$ (from Knackfuß 1908, pl. 3, 6, detail).
Having Messene in mind, we may assume a similar re-dedication of the thesauros chamber in the Milesian bouleuterion, if it was not a grave from the very beginning; this had been assumed by Theodor Wiegand in the excavation report of $1902^{69}$.

Who may have been buried there we do not know. At least is the chamber of the same date as the whole building that is between 175 and 163 BC. Was it therefore intended to hold the remains of the dedicators of the bouleuterion after their death, the brothers Timarchos and Herakleides ${ }^{70}$ ?

It is even possible that Gaius Iulius Apollonios and Gaius lulius Epikrates came to rest here later on. This is suggested by two monumental votive inscriptions, ingeniously restored by Peter Herrmann in 1994 (figs. 17a-b). The dedications, delivered by the Milesian demos, adress the heroes Gaius Iulius Apollonios and his son Gaius Iulius Epikrates ${ }^{71}$. As both dedications were inscribed in the walls of the assembly hall, the assumption is compelling that the hero cult of Apollonios as well as the future(?) cult of Epikrates ${ }^{72}$ were incorporated

soul and compared this with how the Messenians asked their heroes to return, when founding the city in $370 / 69 \mathrm{BC}$ : Pausanias 4.27.6; see below.

69 Cf. Wiegand 1902, 151, 154. The large 'lewis hole' in the northern covering slab, mentioned by Knackfuß 1908, 34 ("die nördliche der beiden großen Deckplatten zeigt auf ihrer Oberfläche ein großes Wolfsloch, ein Beweis, dass diese Platte als Verschlußplatte von oben eingesenkt worden ist") may be used for libations, depending on whether the hole goes through the slab or not. The whole matte deserves further investigation.

70 On both see Hommel 1976; Herrmann 1987; Schaaf 1992, 53 f. 59 f.; Herrmann 1997, 155; Nawotka 1999, 153 f.; N. Ehrhardt in: Herrmann et al. 2006, 154; Schollmeyer 2011, 19; Bol 2011, 7. 71 C. Fredrich in: Knackfuß 1908, 107 f. no. 6, 118 no. 15; corrected reading: Herrmann 1994, 229-234 figs. $1-2$ and 1997, 156 no. 6 (C. Iulius Epikrates, son of heros Iulius Apollonios), 159 no. 15 (heros C. Iulius Apollonios, father of Epikrates). See especially Herrmann 1994, 233 with n. 130 on the formulaton kaӨı́ inscriptions.

72 In no. 6 Epikrates is not adressed as heros but as son of a heros. This results in two assumptions: 1 . Epikrates is not a heros yet, 2 . he is still alive. Nevertheless, it is remarkable that he receives a dedicatory inscription by his fellow citizens. The heroization of living persons is
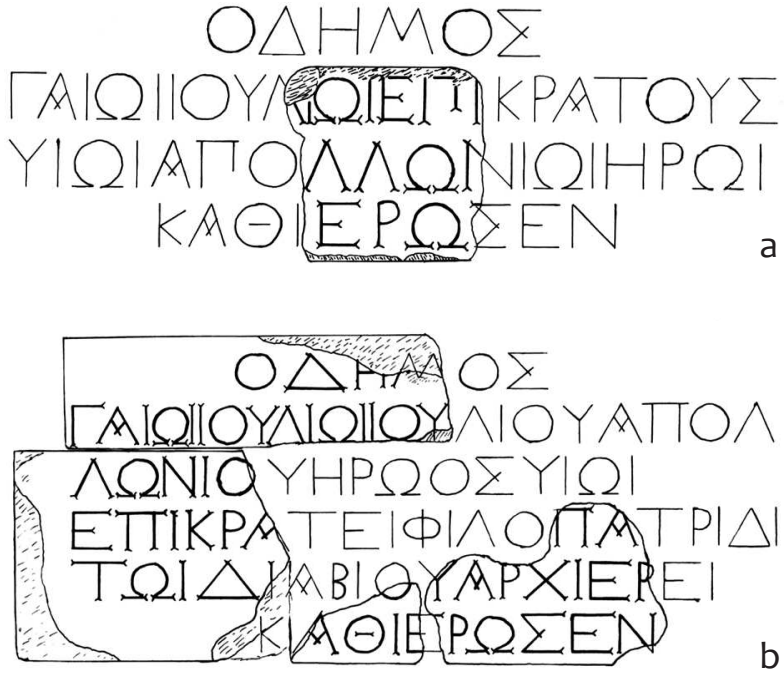

Fig. 17a-b : Reconstructed monumental votive inscriptions from the inner wall of the assembly hall of the Hellenistic bouleuterion. Height of letters 9-12 cm.

a. for heros Gaius Iulius Apollonios (Herrmann 1997 no. 15), b. for Gaius Iulius Epikrates, son of heros Iulius Apollonios (Herrmann 1997 no. 6), length c. 1.8 m (from Herrmann 1994, 231 f. figs. 1-2).

within exactly this building, at their possible grave in the 'thesauros'.

Burials in bouleuteria and other public buildings are a rare honour, comparable to a grave in the agora, often reserved only for a heros ktistes, a heroic founder (see below $\S \mathrm{V}, \mathrm{VIII}$ ). One of the best-known examples come from Megara, where we have plenty of information thanks to Pausanias. In Megara, the public buildings were erected in a former burial ground, incorporating the graves of local heroes: in the bouleuterion was buried Timalkos, the son of the eponymous hero Megareus, in the prytaneion lay his brother Euhippos, together with Ischepolis, son of Alkathoos. The heroon of

a phaenomenon appearing since the $5^{\text {th }}$ century $B C$, see below $\S X$ with n. 267. 
Alkathoos itself was used as archeion 73 . The reason for the Megarians to integrate the hero-graves into their buildings was not a mere matter of lacking space in the course of progressing urbanisation or out of pure respect for the dead. Instead Pausanias was told that the hero Aisymnios, the "judge", obviously the eponym of the political office of aisymnetia and later to be buried in his office building, the Aisymnion, received an oracle in Delphi "that they would fare well if they took counsel with the majority. This utterance they took to refer to the dead, and built a council chamber (bouleuterion) in this place in order that the grave of their heroes might be within it"74. In this regard they were also able to protect the political assemblies of the Megarians - or that of the Milesians 75 .

An essential aspect of Greek hero cult consequently becomes clearer: heroes are presumed to be actively involved in the matters of the living, acting as supernatural powers 'out of their graves ${ }^{\prime 76}$. Another important aspect is the linking of the hero's power to his grave and his dead body. Bones or ashes of heroes, taken to another place (translatio), can evoke the hero's supernatural powers in the interest of its new owners, while the former owners are weakened. A famous case in point is delivered by the Spartans in the time of Lydian king Kroisos (first half of $6^{\text {th }}$ century BC).

73 Pausanias 1.42.4, 1.43.2 f., 1.43.4; cf. Curti/van Bremen 1999, 25; Burkert 2011: 293 with n. 8. Schörner ommits Megara, "da die Gräber für mythische Heroen in dieser Untersuchung keine Rolle spielen” (Schörner 2007, 109 n. 904).

74 Pausanias 1.43.3 (transl. W.H.S. Jones). On the difficulties with differenciating the prytaneion from the Aisymnion and bouleuterion see Highbarger 1927, 17 f.; Hanell 1934, 146 f. with n. 6. To me it seems likely to equate the Aisymnion with the prytaneion of Megara, as the office of the aisymnetes is equal with that of the archprytanis, e.g. in Miletos, which delivers the closest resemblance to the political structure of Megara; see Herda forthcoming c. On the urbanization of Megara see now Mertens 2010, 56-60 with fig. 1. 75 Bohringer 1980; Hölscher 1998, 34 f., 44, 120 fig. 11. See the striking characterization by Curti/van Bremen 1999, 25: "Both the city's boundaries and the area inside the walls are physically - and ideologically - marked in an almost obsessive way by a series of funerary monuments, heroa; even political buildings like the bouleuterion and the civic archive are built over tombs known to Pausanias as those of mythical heroes. Literally underlying the archaic city is an early geometric necropolis, whose tombs obviously acquired their specific heroic identity over time. The result was a city where the funerary world was enlisted to define the world of the living, and in particular that of politics. The various mythical and mythistorical heroes mark the civic space, providing a guarantee for the function and the validity of the main infrastructure of the polis". 76 Cf. queen Atossa in the Persians (II. 598 ff.) of Aischylos, where she asks the soul of her dead husband Dareios to help the Persians against the Greeks: cf. Herda 1998, 43 f. During the Anthesteria the dead souls climb up to the surface and move around in the city: Burkert 2011a, 296, 360. See below $\S \S V I$ and X.
They stole the bones of Orestes from Tegea and brought them to Sparta, in preparation of their war against Tegea77. Another striking case, this time to the disadvantage of the Spartans, is the foundation of the city of Messene in 370/69 BC. One of the rituals performed by the Messenians was to "summon the heroes to return and dwell with them" in the new city ${ }^{78}$, building up a special class of 'patriotic heroes' 79 . The contemporaneous increase of the bringing of offerings to Mycenaean graves in the region of Messenia again exemplifies the socio-political function of hero cults as "focuses of Messenian nationalism"80.

A very special instance of bone-translation can be seen in the treatment of Solon's remains: the Athenians scattered his ashes all around Salamis. With this symbolic act they made the heroized sage and statesman, who had gained the island for Athens and could not be removed from this land again, an eternal guarantor of the new possession ${ }^{81}$.

77 Herodotus 1.67-68; cf. Pfister 1909, 76 f., 196 f.; McCauley 1999; Parker 2011, 117 f., 121.

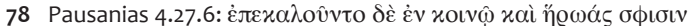

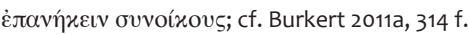

79 For this term see Kron 1999.

80 Antonaccio 1995, 70-102; Boehringer 2001, 243-371; Parker 2011, 119. A critical revision of the evidence is now presented in Mangoldt forthcoming. Secure hero-cults: Mangoldt forthcoming, catalogue nos. A5 (Antheia, Mycenaean tholos grave, cult: early $3^{\text {rd }}$ century BC), A27 (Voidokolia, 'grave of Thrasymedes', Middel Helladic tumulus, cult: $4^{\text {th }} / 3^{\text {rd }}$ century BC); supposable: B11 (Kopanaki, Mycenaean tholos, cult: Classical-Hellenistic?), B19 (Kremmidia, tholos grave 3, Mycenaean, cult: Late Classical-Early Hellenistic), B22 (Nichoria, LH III A/B tholos, cult: $5^{\text {th }} / 4^{\text {th }}$ century BC), B24 (Peristeria, tholos grave $1, \mathrm{LH}$ III A/B, cult: $4^{\text {th }} / 3^{\text {rd }}$ century BC), B27 (Volimidia, grave Angelopoulos 6, Mycenaean, cult: Geometric and Hellenistic-Roman); insecure: $\mathrm{C}$ 19 (Soulinari, Mycenaean tholos, cult: Archaic and Hellenistic?), C29 (Tragana, tholos gave 2, LH I, cult: Hellenistic and Late Roman?), C 30 (Vathirema, rock-cut chamber tomb, Mycenaean?, cult: Classical?). 81 Aristotle fr. 392 R; Diogenes Laertius 1.62; Plutarch, Solon 32.4; Farnell 1921, 361; Malkin 1987, 83, 218; see below § VII with nn. 174 $\mathrm{f}$. Against this stands the $2^{\text {nd }} / 3^{\text {rd }}$ century AD tradition, preserved in Aelian, Varia historia 8.16 that Solon had a public grave encircled by a wall, close by the city gates of Athens, on the right side when one

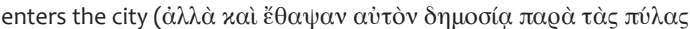

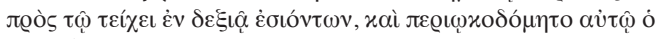

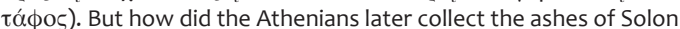
in Salamis? Ignoring the Aristotelian tradition, Kübler 1973, 190 tracked the Aelian-story down to $4^{\text {th }} / 3^{\text {rd }}$ century BC Phanias, a pupil of Aristotle, and subsequently wanted to identify a mid- $6^{\text {th }}$ century $\mathrm{BC}$ grave stele, depicting a young warrior and found near 'Tumulus G' in the Kerameikos, with the grave of Solon. This was declined by Knigge 2006, 128-135, who instead proposed an early Classical tumulus north of the Dipylon Gate and close to the Demosion Sema (ibid. 129, fig. 1 "Tumulus am Dromos"; cf. Knigge 1988, 159, no. 59 figs. 154,165 ) as Solon's grave. But as Knigge 2006, $134 \mathrm{n}$. 20 herself stresses, this tumulus was hidden under an earth filling of some meters height already in the early $3^{\text {rd }}$ century BC, 500 years before Aelian wrote. Also a bronze urn including ashes was found in the tumulus (Knigge 1988, 160 fig. 154). Knigge 2006, 132 with n. 14 believes the ashes to be that of Solon, collected by Themistocles in 
A final argument for searching the heroon of Gaius Iulius Apollonios and Gaius Iulius Epikrates within the bouleuterion of Miletos is given by the fact that the cult of heroic ancestors is closely associated with the sacred hearth of public buildings as well as private houses ${ }^{82}$. As already mentioned was the hearth of Hestia Boulaia located in the assembly hall of the Milesian bouleuterion ${ }^{83}$. The same spatial closeness has to be assumed for the graves of mythical heroes such as Timalkos in the bouleuterion of Megara or Euhippos, Ischepolis and Aisymnos in the Megarian prytaneion. Antinoe, the daughter of Kepheus, who had helped the Mantineans to found their city, delivers one of the rare cases of a heroine, being venerated as heroine ktiste. Her grave was located in the agora, had a round shape and was significantly called Koıv̀े Eoría ${ }^{84}$

\section{The heroon of Thales, act 1: Geoarchaeology meets Greek myth}

My approach to the grave of Thales is the result of geoarchaeological research, conducted in Miletos together with Helmut Brückner and Marc Müllenhoff since the last decade ${ }^{85}$. In the course of our investigations regarding the early history of the central sanctuary of Miletos, the Delphinion, we got more and more involved in the palaeogeography

\footnotetext{
Salamis and re-buried at the Dipylon. This is highly speculative, to put it mildly. When we at least accept the reliability of Aelian, we have to assume in the $2^{\text {nd }}$ century $A D$ a grave precinct, enclosed within a wall, perhaps including also a cenotaph, while the ashes of Solon stay in Salamis.

82 Pfister 1909, 460 (he compares it with the cult of the Roman Lares); Farnell 1921, 356. Dionysius of Halicarnassus 4.2 in accordance

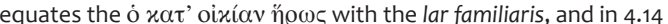
he speaks of See also the cult of the Roman Penates at the hearth, or that of the Etruscan dii animales: below n. 263. For the purifying function of the fire in hero cults see n. 229

83 See above §II with nn. 40 and 47 . The most sacred hearth of the polis, that of Hestia Prytaneia, was to be found in the Molpon, the house of the cult association of Apollo Delphinios in the Delphinion, see below with n. 91; § VII with n. 172.

84 Pausanias 8.9.5; cf. Fougères 1898, 316; Pfister 1909, 460; Farnell 1921, 356a, 358, 414 n. 127a. The grave is identified with a free-standing circular stepped stone monument, 6,10 $\mathrm{m}$ in diameter, with a "mill-stone" (Fougères 1898, 194 "meule") in the center. It is located west of the theater and directly in front of the northern stoa of the agora: Fougères 1898, 180 fig. 44 ("Foyer commun?"), pp. $193 \mathrm{f}$. (because of the small diameter he reconstructs a round altar, surrounded by a balustrade, not a tholos with columns and a roof). 85 Herda 2005, 250-258 figs. 5-10; Brückner et al. 2006; Müllenhoff et al. 2009a and 2009b; Brückner et al. forthcoming.
}

of the city centre and, finally, of the whole city. It turned out that large parts of the late Archaic, Classical and Hellenistic city ground were originally marine and made dry by filling in a mixture of stone, earth and artefacts. It can be detected for part of the Delphinion, of the southern Lion Harbour and of the North Market. The finds in our corings hint at a date of the fillings in the $6^{\text {th }}$ to early $5^{\text {th }}$ century $B C$ (fig. 18).

These results were really exciting and called into my mind a passage in Plutarch's life of Solon, where he was talking about one of the other Seven Sages, the famous Milesian Philosopher Thales (Plutarch, Solon 12.11.1-12.1):

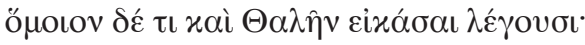

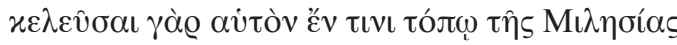

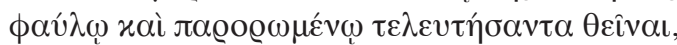

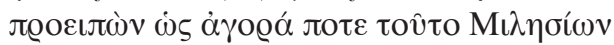

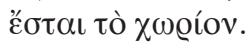

"A similar insight into futurity is ascribed to Thales. They say that he gave directions for his burial in a cheap and disregarded place of the Milesian territory, predicting that it would one day be the agora of Miletos."

[slightly changed trans. by B. Perrin]

Certainly, this is a late anecdote about a sage, of whose sayings we have nearly no direct testimonium preserved, except inter alia perhaps

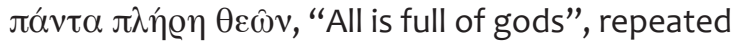
by Aristotle ${ }^{86}$. But as in most anecdotes there is a hidden historical core. And this core is two- if not three-fold in the case of Thales' grave: During Thales' livetime - he died in the mid- $6^{\text {th }}$ century $\mathrm{BC}-{ }^{87}$ the city of Miletos was totally replanned in

86 Aristotle, de anima 1.5.411a 8 (= 11 A 22 Diels/Kranz); cf. Betegh 2002, 237; Burkert 2011, 462. Despite modern 'wishful thinking' the Ionian 'Presocratics' (as also Socrates, the alleged asebes!) never doubted the existence of the gods resp. a divine principle. 87 According to the Hellenistic chronographer Apollodorus (Apollodor FGrHist 244 F 28 = Diogenes Laertius 1.37 = Diels $/$ Kranz $11 \mathrm{~A} 1$ ) was Thales born in the $35^{\text {th }}$ Olympiad (640-637 BC) and died at the age of 78 , resulting in a date between 562 and $559 \mathrm{BC}$. This date is too high, as we known from Herodotus ( $1.75=$ Diels/Kranz $11 \mathrm{~A} 6$ ) that Thales took part in the campaign of the Lydian king Kroisos against the Persian king Kyros in 546 BC. Diels/Kranz 1974, 72 in a note on 11 A 2.27 on Suidas s.v. $\Theta \alpha \lambda \hat{\eta} \varsigma$, where the same high birth date in the $35^{\text {th }}$ Olympiad is given, therefore remarked: "Ol. 35 stammt aus der korrupten Quelle des Diog[enes, A.H.] (...), wie Euseb. A $7(175,17)$ ". They correct the birth date to Ol. 39 (624-621 BC) assuming that Thales had his akme with 40 years in May 28 of $584 \mathrm{BC}$, when he predicted a solar eclipse to the lonians during the war of Lydian king Alyattes against Median king Kyaxares (Herodotus 1.74 = Diels/Kranz 11 A 5; see: Hahn 2001, 253 f. n. 45; 


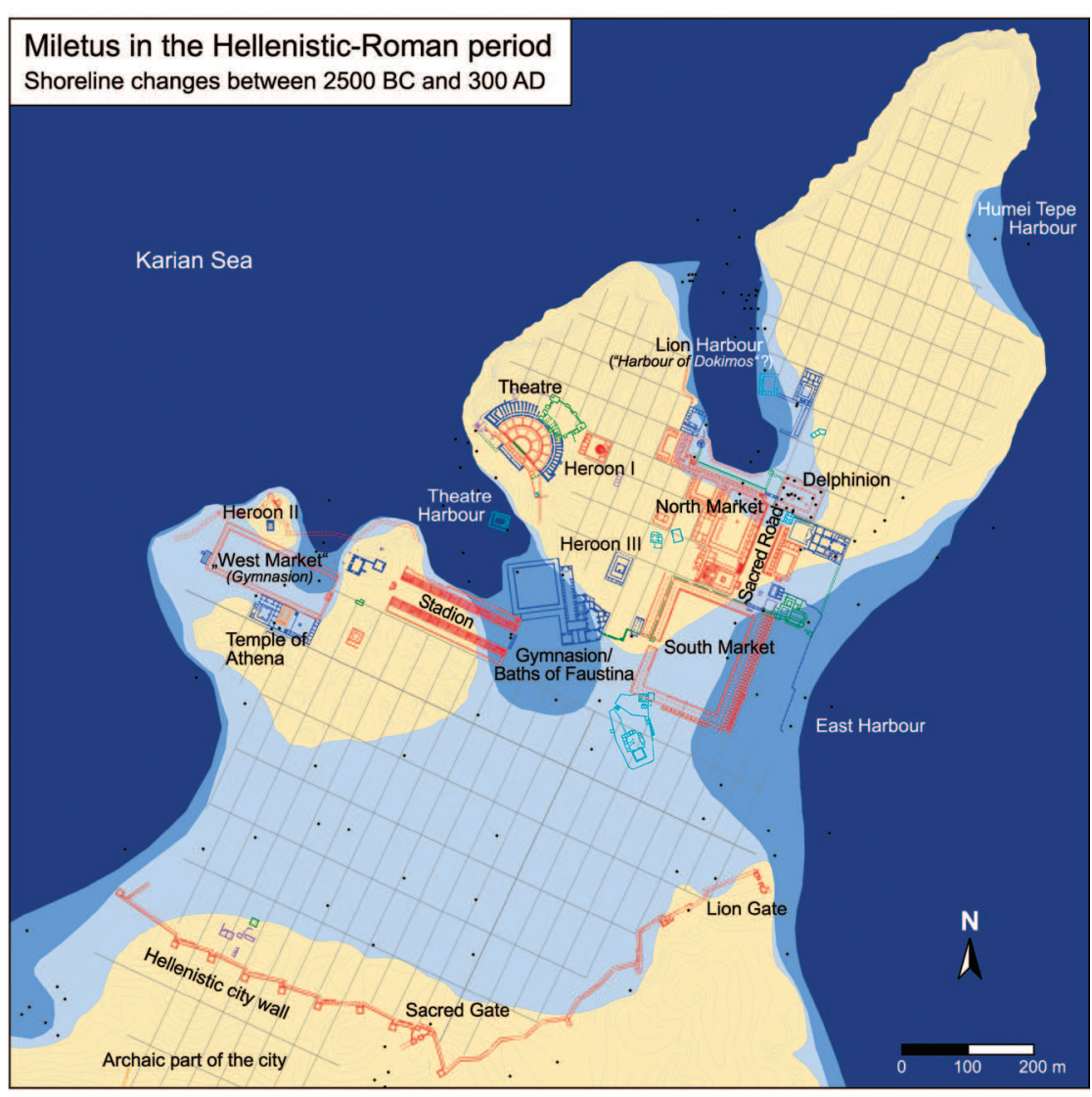

Fig. 18 :

Palaeogeographic

map of Miletos

with building phases in

relation to the shorelines

(Marc Müllenhoff,

author, and Helmut

Brückner).

\begin{tabular}{|c|c|c|c|}
\hline \multirow[b]{2}{*}{ م } & age of buildings & distribution of land and water area & $\frac{\pi}{0}$ \\
\hline & modern & land area at maximum transgression (around $2500 \mathrm{BC}$ ) & 弿 \\
\hline & Islamic & water area at maximum transgression & \\
\hline 2 & Byzantine & water area during Archaic time & $\frac{\mathrm{u}}{\frac{\pi}{\alpha}}$ \\
\hline H & Roman Imperial time & water area during Roman Imperial time & 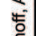 \\
\hline$(1)$ & Classical-Hellenistic & coring site & 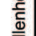 \\
\hline HII & Archaic & contour lines & $\sum_{0}^{\bar{n}}$ \\
\hline Iu & ambiguous age & map based on: & $\stackrel{\substack{\pi \\
\pi}}{\pi}$ \\
\hline \pm & $\searrow$ street-insulae-grid & $\begin{array}{l}\text { Bendt, W. (1968): Topographische Karte von Milet, M 1:2.000 (Milet II, 4); } \\
\text { geophysical survey CAU Kiel, Dr. H. Stümpel; own topographical survey }\end{array}$ & $\sum_{\substack{\grave{0}\\
}}$ \\
\hline Source: & $\begin{array}{l}\text { Marc Müllenhoff, Alexander } \\
\text { Deciphering Palaeogeographi }\end{array}$ & $\begin{array}{l}\text { Helmut Brückner (2008): Geoarchaeology in the City of Thales - } \\
\text { s in the Agora Area of Miletus. Philippika, 1: } 97-110 ; \text { Wiesbaden. }\end{array}$ & 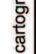 \\
\hline
\end{tabular}

a street-insula-grid system. This system was first realized in newly developed districts, for example the areas south of the Lion Harbour and northeast of Kalabak Tepe ${ }^{88}$, while the old districts kept their

Graham/Hintz 2007, 331). Sosikrates instead (fr. 10 FGH IV $501=$ Diogenes Laertius $1.38=$ Diels/Kranz $11 \mathrm{~A} 1)$ kept the $35^{\text {th }}$ Olympiad but prolonged the lifetime auf Thales from 78 to 90 years, because he knew of Thales dying in Ol. 58 (548-545 BC). This seems less convincing as we know that Thales had his akme (in the age of c. 40) in the year of the Athenian archon Damasias (582/1 BC): Diogenes Laertius I.22 (= Diels/Kranz 11 A 1); cf. Kirk et al. 2001, 84 n. 1. 88 Herda 2005, 281-285 fig. 30; Herda in preparation. For the Archaic districts NO of Kalabak Tepe with a grid system see Graeve 2006, 258-262, 257 fig. 8; Grave 2009, 26 fig. 1. It is detected via geophysics (Stümpel/Erkul 2008, 28 f. fig. 4), but one of the $4.30 \mathrm{~m}$ traditional appearance of an irregular, 'grown' street-net, until the Persians destroyed the city in 494 BC. The only important exception was made with the late Archaic temple of Athena, whose construction necessitated the demolishing of a whole district in the oldest settlement core ${ }^{89}$.

broad North-South-streets of the grid was already excavated by Armin von Gerkan in 1908/9: Gerkan 1925, $39-44$ figs. 29-30 Beilage 1 (see in trenches IV-VI, but the position of the trenches is not exactly rendered, the street has the deviation of $24^{\circ}$ clockwise from geographical North as also the Late Archaic temple of Athena). 89 Weber 2004a, 145 and 2004b, 235-237; Herda 2005, 282-284, 291 f.; Weber 2007, 355-359. 


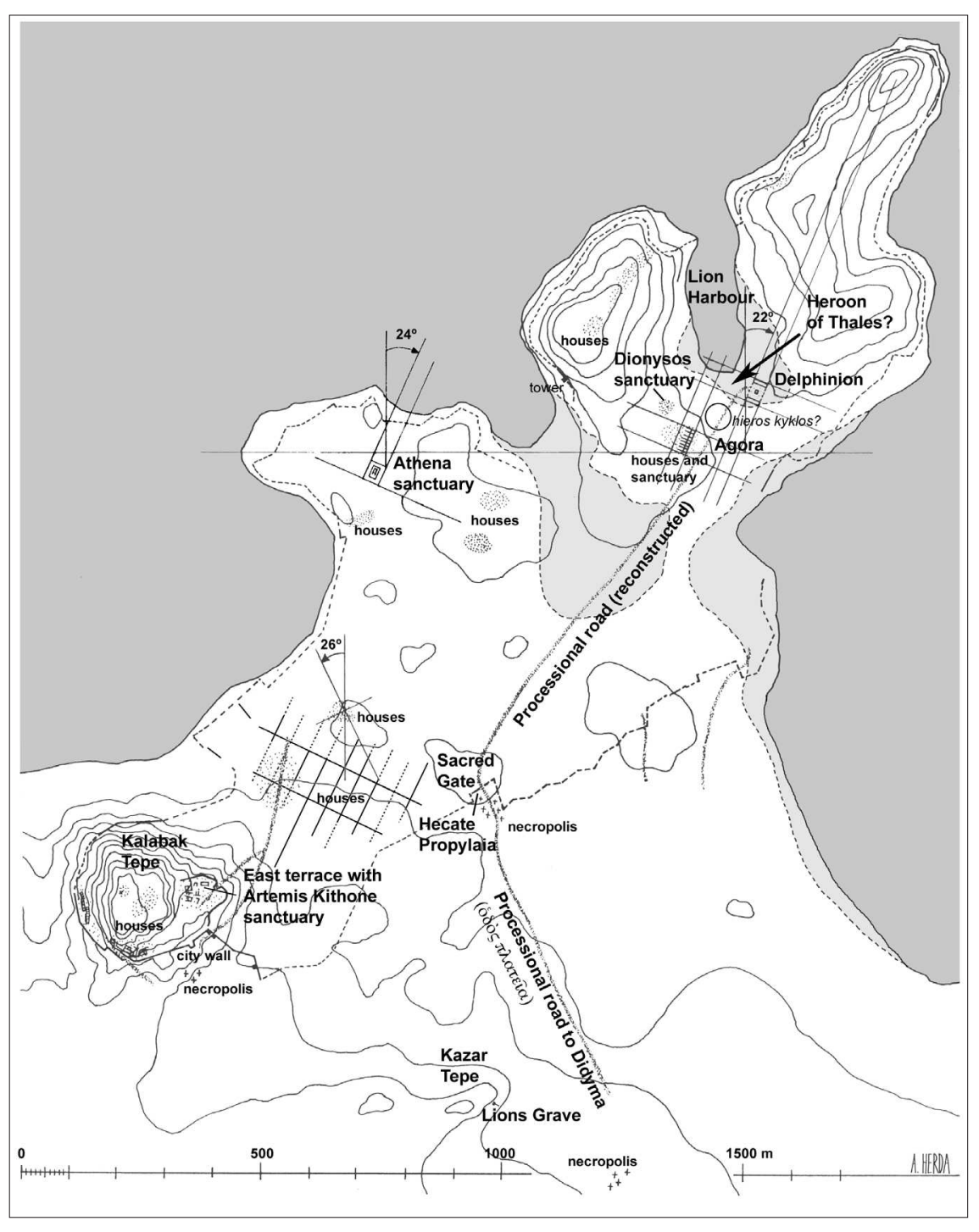

Fig. 19:

City map of Archaic

Miletos with detected

Archaic street-insula-grid,

maximum extension of

sea in Early Archaic times

(light grey), and assumed

position of Thales'

grave in area of artificial

drainage (drawing

author).

The agora of this new Miletos can be located between the Archaic sanctuaries of Dionysos and Apollo Delphinios, serving as space for religious as well as political assemblies, with the hieros kyklos, the "sacred circle" in its center". The Delphinion incorporated not only the main city cult, controlling citizenship, but also the prytaneion, the governmental seat of the polis state, usually to be expected close to the agora (fig. 19) ${ }^{91}$.

The deep drillings detected an extension of the agora to the north, made possible by draining the

90 Herda 2005, 272-279 figs. 25, 29 and 2011, 70-74, 64 fig. 2 .

91 Herda 2005, 247-250 and 2011, 62-70. I hold the southern hall of the Delphinion for the Molpon-prytaneion. marshy southern extension of the Lion harbour. Is this also the area, where we have to search

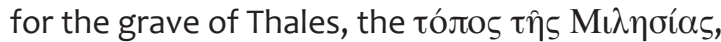
which is described as being originally $\phi \alpha \hat{\nu} \lambda$ o $5 \alpha i$

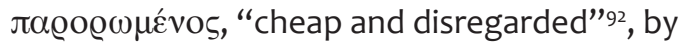
Plutarch? This assumption has a high probability to me93.

92 For $\phi \alpha \hat{\jmath} \lambda$ o s see LSc s.v.: "cheap, easy, slight, paltry”, I. of things, 1. "easy, slight", 2. "simple, ordinary", 3. "mean, bad”. For

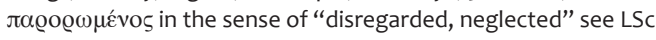

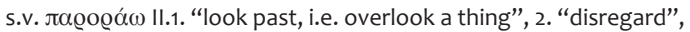
3. "neglect".

93 Cf. Herda 2005, 278-280; Müllenhoff et al. 2009, 108. 


\section{The cult of the founder in Greek agorai}

Locating a grave in an agora is very exceptional. Actually the agora is the most prominent place for a grave, restricted only to very few persons, to whom it is the highest honour, a polis can give.

Very typical recipients of this honour are the founders, the heroes ktistai, who "were buried in the middle of the cities by habbit"94. Probably the best-known example is that of Aristoteles in Kyrene, a $7^{\text {th }}$ century BC colony of Thera. Aristoteles, son of Polymnestos from Thera, who had the nickname Battos, "the stammerer", got a grave as well as a hero-cult in the agora, while his royal successors were buried "far away in front of their houses". This is described by Pindar in the fifth Pythian Ode (II. 93-98) for Arkesilas of Kyrene. The heroon of Battos was found by the Italian excavators on the eastern end of the agora, consisting of a tumulus grave and less probably also a separate sanctuary ${ }^{95}$. A sacred law from Kyrene, relating to taking part in sacrifices "for Battos the first leader" (Bó $\tau \tau \omega$ $\tau \hat{\omega} \alpha \varrho \chi \alpha \gamma \varepsilon ́ \tau \alpha)^{96}$, as well as for "Onymastos the

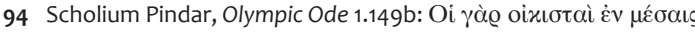

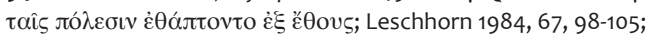
Malkin 1987, 200-216, 237-240; Schörner 2007, 118 f.,196 f., 206 f.; Cordano 2009.

95 Stucchi 1965, 33-65 figs. 11 f., 100 f. figs. 50 f., 111-115 figs. 58-61, 122 f. fig. 64, 128 f. fig. 66, 139-142 figs. 74 f., 143 fig. 76, pls. 13.2, 20.56, 21.1-3, 24.2-4; Büsing 1978; Malkin 1987, 204-216; Schörner 2007, $21 \mathrm{f}$., $42 \mathrm{f}$., 85 f., 150, 213-216 A3 figs. 15-23. The connection between the tumulus grave and the adjacent sanctuary to the south (so e.g. Schörner 2007, 22, 43, speaks of “Kultstätte (Oikos)", but see ibidem 150 , where she treats it as separate sanctuary of a trias!), seems not very convincing to me. First of all, the sanctuary has a different orientation (at least from the second half of the $5^{\text {th }}$ century BC toward the South). The temenos wall, which excludes the tumulus grave (Schörner 2007, fig. 18), includes three altars (Schörner 2007, fig. 21 f.), hinting at the cult of three deities being practised within it. This corresponds with the three-partite structure of the oikos in the first phase (Schörner 2007, figs. 18, 20). Stucchi 1965, 34-58 thinks of a heroon for the daimon Ephialtes Opheles (because of a

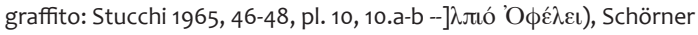
2007,86 favours a sanctuary of Apollo. I wonder if the sanctuary was dedicated to the Tritopateres, "the fathers in the third generation", who recieved cult together with Battos according to the famous $4^{\text {th }}$ century BC sacred law from Kyrene, referring to the foundation oracle of Delphian Apollo for Kyrene: Rhodes/Osborne 2003, 494505 no. 97.22 f.; see Leschhorn 1984, 68, 102, who adresses the Tritopateres as "alte Stammväter der Kyrener"; see also Rhodes/ Osborne 2003, 502 f.; see below n. 246.

96 The title archagetas, the "first leader", instead of oikistes, oikister, ktistes, "founder", here given to Battos, was usually attributed to the oracle god Apollo Pythios, sanctioning the Greek colonial enterprises: Malkin 1987, 241-250; Schörner 2007, $135 \mathrm{f}$. The title is also an epitheton of Apollo Didymeus, the oracle god sanctioning the Milesian colonisation, e.g. of Kyzikos: Aelius
Delphian" and the Tritopateres, makes clear that the grave of a city founder or hero was exempted from the idea of ritual pollution (mysos, miasma) and could therefore be placed within the city97.

A striking other example is the grave of the Sikyonian general Aratos, who died in 213 BC. The Sikyonians, who wanted to bury him in their city, most probably in the agora, could not do so because of an "ancient law", forbidding to bury "within the city walls" of Sikyon. This law obviously protected the ritual purity of the city, as similar laws did in other cities ${ }^{98}$, with the striking exception of Sparta, where Lykurgos allowed the Spartans to "bury their dead in the city, and to have memorials of them near the sacred places"99. The Sikyonians solved the problem by asking the oracle in Delphi for permission. Apollo, the divine authority of cleaning and purity, "the purest of gods"100, who was also prominent as protector from plagues in the

Aristeides, Orationes 16.237; cf. Herda 2008, 28-30, 55 with n. 325, p. $57,59,61,62$. Only attributed to gods seems to be the alternative title hegemon, "leader": Herda 2008, 28 with n. 117. 97 SEG IX 72; Parker 1983, 336-339; Malkin 1987, 206-212; Rhodes/ Osborne 2003, 494-505 no. 97, esp. pp. 502 f. on $\S 5$ of the law (II. 21-25), which is very difficult to understand. Besides Battos are mentioned the Akamant(i)es, "Onymastos the Delphian" and the Tritopateres. Jameson et al. 1993, 110 remark, to my mind convincingly, that "they alone among the dead carry no danger of pollution (literally, 'there is ó $\sigma i \alpha$ for everyone')”; cf. Parker 1983, 42 n. 39, p. 338; Rhodes/Osborne 2003, 503. Compare also the "pure" Tritopateres in the lex sacra from Selinous, where they are supposed to get sacrifices in the agora, too, see below n. 110.

98 Plutarch, Aratus 53; cf. Leschhorn 1984, 326-331; Malkin 1987, 233-237; Schörner 2007, 14 f., 121 f. 272-274 (B 16); Parker 2011, 104 n. 4. Death causes ritual impurity, a pollution (mysos, miasma), which calls for ritual cleaning. Therefore death-related things are regularly excluded from sanctuaries and the city: Parker 1983, 32-73, 338; Burkert 2011a, 125 f., 138, 293. See on related funeral laws: Frisone 2011, 184, 186, 190, 194

99 Plutarch, Lykurgos 27.1 (transl. B. Perrin); cf. Schörner 2007, 6 n. 38, 12 f., 202; Frisone 2011, 190 f. According to Plutarch, Lykurgos did so "thus making the youth familiar with such sights and accustomed to them, so that they were not confounded by them, and had no horror of death as polluting those who touched a corpse

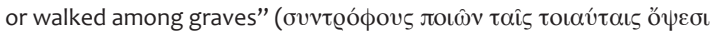

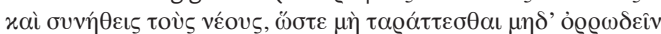

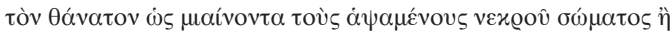

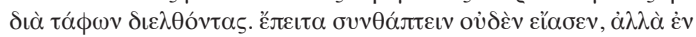

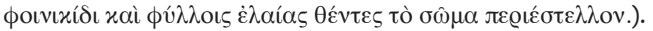
For graves within the city of Sparta: Schörner 2007, 289-297 (A1-7, B 1-8). McCauley 1999, 86 n. remarks, that "there is no indication that they [the Spartans, A.H.] allowed burial of ordinary persons within the precincts of the agora itself".

100 Parker 1983, 67. See ibid. 393 where Parker hints especially at Apollo's role in the cathartic law of Kyrene. He explains Apollo's and his sister Artemis' role as cathartic gods with their “(...) role as senders and healers of plague. (...) The connection of thought becomes almost explicit when the Athenians purify Delos in response to plague." 
agora of Sikyon itself ${ }^{101}$, sanctioned their project by declaring ${ }^{102}$

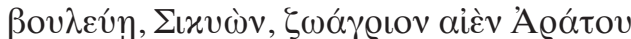

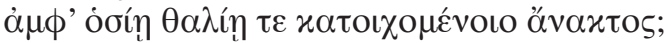

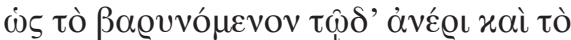
ßa@v̂vov

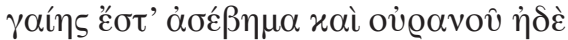
$\theta \alpha \lambda \alpha ́ \sigma \sigma \eta 5$.

"Would'st thou, O Sikyon, pay Aratos lasting honour for the lives he saved, And join in pious funeral rites for thy departed lord?

Know that the place which vexes or is vexed by him Is sacrilegious, be it in earth or sky or sea". [transl. B. Perrin]

Decisive here is Apollo declaring the place of burial as $\dot{\alpha} \sigma \varepsilon \hat{\beta} \eta \mu \alpha$, "impious", "profane”"103, exempting it from matters of ritual impurity. Also, he calls the festivities for Aratus óoí $\theta \alpha \lambda i$, "profane festivities", stressing that they are 'allowed' and not forbidden by divine law'104.

The Sikyonians immediately reacted by "choosing out a commanding place, they buried him there, calling him founder and saviour of the city"105.

101 Pausanias 2.7.8: procession to remember the return of Apollo and Artemis to Sikyon for healing the city from plague, starting from the temple of Peitho (the gods had to be "convinced" to come back) in the agora of Sikyon to the Sythas river and back; cf. Lolos 2011, $379 \mathrm{f}$. The two gods had left Sikyon in mythical times, when it was still an indigenous settlement called Aigialeia: Pausanias 2.5.6; cf. Lolos 2011, 379 f., 384. The cult of Apollo as well as the procession seem to be at least of Archaic age. The Aristotelian Corpus mentiones an old temple of Apollo, which was in ruins in the time of Pausanias: [Aristoteles], Mir. ausc. 834b24; Pausanias 2.7.8; cf. Lolos 2011, 380 f. fig. 6.1 identifying a temple in the agora, having an Archaic and a Hellenistic phase, as the old temple of Apollo. 102 Plutarch, Aratus 53.3.

103 Cf. LSc s.v. ảoé $\beta \eta \mu \alpha:$ "impious or profane act, sacrilege, opp.

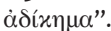

104 On hosios as exact complement to hieros: Burkert 2011, $403 \mathrm{f}$.

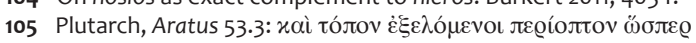

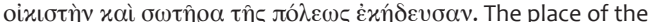

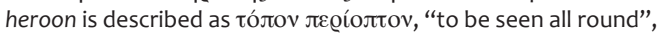
what implies a location on a large, empty space, presumably the agora of Sikyon. This is confirmed by Pausanias who describes the heroon as being placed in front of the house of the tyrannt Kleon at the agora: Pausanias 2.8.1; cf. Leschhorn 1984, 328. Malkin 1987, $234 \mathrm{f}$. thought of a newly established and therefore so far 'graveless' agora of Sikyon as the place of the heroon, which then had caused the Sikyonians to consult Delphi. But there is no hint at an old and a new agora in Sicyon. In 303 BC Demetrios Poliorketes had only relocated the settlement to the acropolis out of security reasons (Diodorus 20.102.3; see Malkin 1987, 233). This does not imply that he also relocated the old, Archaic agora, where the graves of the
Yearly sacrifices ( $\theta u \sigma i ́ a)$ took place at the heroon, called Arateion, for Zeus Soter and Aratus at the date he had saved the city from tyranny. Another yearly sacrifice was offered to Aratos at his birthday by his own priest ${ }^{106}$.

Graves as well as cenotaphs, empty 'symbolic' graves, of other founders were discovered, as in the agora of Poseidonia-Paestum, a colony of Sybaris in southern Italy ${ }^{107}$.

Most recently a cist grave of the $7^{\text {th }}$ century BC within a small precinct, found in 2003 in the middle of the agora of Selinous-Selinunte in Sicily, a joint colony of Megara and its colony Megara Hyblea, has been identified as heroon of the Megarian oikistes Pammilos ${ }^{108}$. To me, a connection with the hero Euthydamos, mentioned in the famous $5^{\text {th }}$ century BC lex sacra from Selinous as being venerated by the Selinuntians together with Zeus Meilichios and the "pure" Tritopateres, the "fathers in the third generation", or 'collective ancestors' of the polis ${ }^{109}$,

heroes Adrastos and Melanippos were located: Herodotus 5.67 cf. Malkin 1987, 235, 237.

106 Cult of Aratos: Plutarch, Aratus 53; see Leschhorn 1984, 326331 who attributes the birthday festival to the cult of the founder Aratos, though he thinks that birthday festivals are not typical for a founder cult (ibid. 329; see also Malkin 1987, 236). The heroon of Aratos has not been found so far: Lolos 2011, 382.

107 Kron 1971 (interpreted as a sanctuary of a female chthonic deity); Greco/Theodorescu 1983, 28-33, 74-79, 139-145, 176 f. figs. 9-20; Pedley 1990, 36-39 figs. 11-13; Rausch 2000 (interpreted as Tritopatreion); Mertens 2006, 166 f. figs. 288 f.; Schörner 2007, 152167 figs. 194-197 (cenothaph); see below § IX.

108 Mertens 2006, 177 fig. 308, 178 fig. 310; Mertens 2010, 80-84 fig. 12, esp. 83 f. on Pammilos of Megara (Thucydides 6.4.2). A second, much more destroyed burial directly south of the grave is connected by Mertens to a second heros ktistes originating from Megara's colony Megara Hyblaia. He is supposed to have joined Pammilos but was, according to Mertens, later on forgotten, his grave was left devastated: Mertens 2010, 80 f. fig. 12, p. 82-84. 109 The most instructive ancient text on the Tritopatores is Harpokration, Lexikon s.v. Tritopatores (Keaney, p. 253) = Phanodemos FGrHist 325 F6 / Demon FGrHist 327 F2 / Philochoros FGrHist 328 F182; cf. Jameson et al. 1993, 107-116; Georgoudi 2001, 155 f.; Gagné 2007 (critical on all sources, incl. Orpheus, Physika F 803 Bernabé = 318 Kern); Higgins 2008, 17 f. On the Tritopatores as collective ancestors of smaller kinship groups (gene, phratries, demes) as well as of the whole polis see Clinton 1996; lles-Johnston 1999, 51 f.; Rausch 2000, 111-116; Georgoudi 2001; Gagné 2007, 2 with n. 5, p. 16; Higgins 2008, 18. On the etymology (composite of

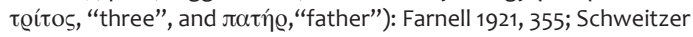
1922, 75 f.; Wüst 1939, 324 f.; Georgoudi 2001, 156; see next note and n. 238.

The Tritopatores are probably depicted in one of the pediments of the so-called Ur-Parthenon on the Akropolis: A. Furtwängler, B. Schweitzer and others have identified them with the so-called Typhon or Bluebeard, a figure with three upper parts of humans and a snake-like lower part, three times interwineded. The figures, dated c. 570/60 BC, hold a bird, and wavy things (water and fire or winds?): Furtwängler 1905, $452-458$ figs. pp. 446-447; Schweitzer 1922, 72-83; cf. Weinreich 1973, 77 f.; Jameson et al. 1993, 112 n. 37; Martini 1990, $235 \mathrm{f}$. fig. 71 (stresses that the middle body is hit by arrows, he leaves 
seems also possible ${ }^{110}$. The ritual delivers an exact

the identification open); Karanastassis 2002, 220 fig. 304b (Typhon?); Stroszeck 2010, 58 n. 24 (refers to the observation of Martini and remarks: "Diese Interpretation des Dreigestaltigen muss als überholt gelten.”); Icard-Gianolio 1994, 561 no. 3 (identified with Proteus). Another early depiction of the Tritopatores, this time as wind-gods, may be found on a Laconian bowl of the so-called Naukratis Painter (c. 560 BC) from Naukratis, now in the British Museum, depicting the nymph Kyrene holding a Silphion plant and a branch of the tree of the Hesperids, surrounded bei winged female (on the left) and male (on the right) genii: Studniczka 1890, 15-27; Harrison 1908, 180 fig. 22 (three figures with beards, wings and winged shoes in right lower corner, interpreted by Studniczka and Harrison as the Boreads). However, this identification is questioned by some scholars: Pipili 1987, 40-44 fig. 54 no. 101 (Artemis Ortheia and winds or less probable: Aphrodite with Erotes, but in the latter case she cannot explain the different sex of the winged figures!). See now also Thomsen 2011, 118-122 figs. 51a-b (goddess of fertility with her entourage), 137-142 (winged male figures are no Boreads). 110 Mertens 2010, $80 \mathrm{f}$. mentions the lex sacra (Jameson et al. $1993=$ SEG XLIII $630=$ Lupu 2005, 359-387 no. 27) but does not go into details. To me, the differing preservation of the two graves seems a matter of later accidental stone extraction. It does not imply that the southern one was devastated earlier. A contrario: The southern temenos-wall around the northern grave clearly respects the southern grave. The southern temenos-wall comes closer to the northern grave than to the southern. The first lies remarkably excentrical within the temenos: Mertens 2008, 475-481 figs. 3-7; Mertens 2010, 81 fig. 12. Maybe the southern grave is the one of Pammilos, while the northern one in the temenos is that of Euthydamos. Euthydamos, "the one beneficial to the demos", and Myskos, "the ritually polluted" (cf. ingeniously Curti/van Bremen

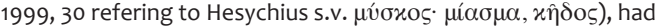
their own heroa and received public sacrifices together with Zeus Meilichios and the impure (Myskos) and pure (Euthydamos)

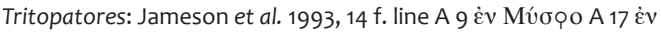

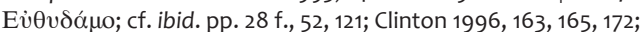
Curti/van Bremen 1999, 27-30; Lupu 2005, $367 \mathrm{f}$. The sacrifice of wine for the "impure Tritopatores as to the heroes" (A 9 f. toîs

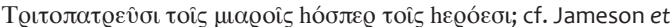
al. 1993, 29 f., 63-67) had to be "poured through the roof" (II. A 10

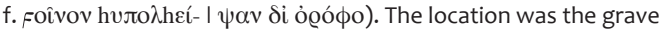
of Myskos, which was probably situated in the Zeus Meilichios sanctuary on the Gaggera Hill outside the city according to Jameson et al. 1993, 30 f., 64, 70-73, 112, 134 and Curti/van Bremen 1999, 30-32 figs. 4-7 (grave of Myskos with installation for libation?; but see Vonderstein 2006, 212: simple wells); cf. Lupu 2005, 368 n. 30. Instead, the libation of a honey mixture (A $13 \mathrm{f}$. ) to the "pure" Tritopatores (A 13 toî $x<\alpha>\theta \alpha$ Qois), performed "as to the gods"

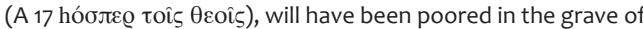
Euthydamos in the agora of Selinous, where Curti/van Bremen 1999, 28 rightly assume also another sanctuary for Zeus Meilichios. Mertens 2010, $81 \mathrm{f}$. mentions a structure SE of the two graves, $4 \times 6$ $m$ in dimension, with a kind of rampart in the North. He interpretes it as the altar of Zeus Agoraios, where the tyrant Euryleon was killed (Herodotus 5.46; Polyaenus 1.28.2). Could it instead be a Sanctuary of Zeus Meilichios or/and the "pure" Tritopatores, which are to be expected close to the heroon of Euthydamos, or does the sacrifice to Zeus Meilichios in the sanctuary of Euthydamos (II. A 17-21) imply that the sanctuary of Zeus was incorporated in that of the hero? In Athens, it seems to have also existed a Zeus Meilichios sanctuary in the 'new' agora in the Kerameikos: several dedications were found between the Hill of the Nymphs and the new agora: Jameson et al. 1993, 82. That the Archaic-Classical Tritopatreion in the Kerameikos necropolis of Athens was a state sanctuary of the Tritopatores of the Athenian people, as supposed by some scholars (cf. Jameson et al. 1993, 107 f.; Lupu 2005, 371; Vonderstein 2006, 210 n. 1601; Stroszeck $2010,56,67,71 \mathrm{f}$.), rests only on the inscriptions of the boundary markers: They do not specify any group-relation. But what speaks analogy to the sacrifices for Battos, Onymastos and the Tritopateres at Battos' heroon in the agora of Kyrene, mentioned above ${ }^{111}$.

In the agora(?) of Amphipolis a Classical cist grave with an urn made of silver was found. Most probably it kept the ashes of the Spartan general Brasidas, who first conquered the Athenian foundation in Thrace and then successfully defended it against the Athenians in $422 \mathrm{BC}$, but died during the battle. For that he was honoured by the citizens with a hero-cult in the agora, according to Thucydides (5.11), as if to say as a second founder, replacing the Athenian Hagnon ${ }^{112}$

Neither a grave, nor a cenotaph, but a mnema, a monument of remembrance, was posthumously erected for Glaukos, the co-founder of the Parian colony Thasos, in the northeastern corner of the cities agora in the late $7^{\text {th }}$ century $B C$ at the earliest. It consisted of a two-stepped basis of an

against this assumption is that the sanctuary was destroyed in the later $4^{\text {th }}$ century BC and never again restored: Stroszeck 2010, $68 \mathrm{f}$. This rather hints at a Tritopatreion of a smaller kinship group (genos or phratry), which got out of function with the termination of this group. J. Stroszeck now assumes the ending of the state cult of the Tritopatores in the Kerameikos in the course of wider historical changes in Athens under Macedonian rule (I thank her very much for discussing these issues with me in Dec 2012). Another argument for the latter interpretation is the presence of a large multi-burial tumulus of ca. $560 \mathrm{BC}$ close by to the West, where the entrance to the Tritopatreion was placed (so-called Tumulus/Hügel G; cf. Knigge 1988, 103-105 with figs. 97-99 no. 14 = Tritopatreion and $15=$ Tumulus, compare figs. 17 and 165 for a site plan; entrance of Tritopatreion: Stroszeck 2010, 62, pl. 29, 1-3), as well as a small tumulus to the east: Stroszeck 2010, 65 f., pls. 25.1, 32.1-2. This had led Kübler 1973, 189 f., 192 (cf. Stroszeck 2010, 66 f.) to assume a Tritopatreion built by Solon, and Knigge 1988, $104 \mathrm{f}$. to assume a sanctuary of a kinship group, an interpretation Knigge 2006 further developed, where she identified the Tritopatreion as that of the Alkmaeonidai; cf. Stroszeck 2010, 55 f. To my mind, the state Tritopatreion of democratic Athens should be expected in the new agora, close to the collective sanctuary of the ten Eponymous Heroes and not to far away from the Zeus Meilichios sanctuary. The extant monument of the Eponymous Heroes in the SW corner of the agora is of the late $4^{\text {th }}$ century BC (cf. Camp 1986, 97-100 figs. 72-74), but a forerunner of the time of Kleisthenes is to be expected close by: Mattusch 1994, 76 with fig. 4. Antonaccio 1995, 125 has proposed the socalled triangular sanctuary in the SW-corner of the agora to be a Tritopatreion: Camp 1986, 78 fig. 54, 142 fig. 120, 155 fig. 129. But the preserved boundary marker misses a specification of the cult and the triangular form of the precinct is no forcible argument: Georgoudi 2001, 154 with n. 11; Stroszeck 2010, 65 with n. 70.

111 Before the graves in the agora of Selinous were found, Vonderstein 2006, 212 (see also ibid. 213) already assumed: "Gut möglich ist, dass sich sämtliche Kultstellen, diejenigen für die Tritopatoren und die für Myskos und Euthydamos, auf der Agora der Stadt befanden, vergleichbar mit dem Befund in Kyrene." For the consequences of this situation on the ritual purity of the agora see below n. 243.

112 Lazarides 1993, 97 fig. 49; Koukouli-Chrysantaki 2002, 66-72, pls. 10A-B, 11B; Schörner 2007, 72 f., 264 f. B8; cf. B. Mangoldt forthcoming, catalogue-no. A1. 


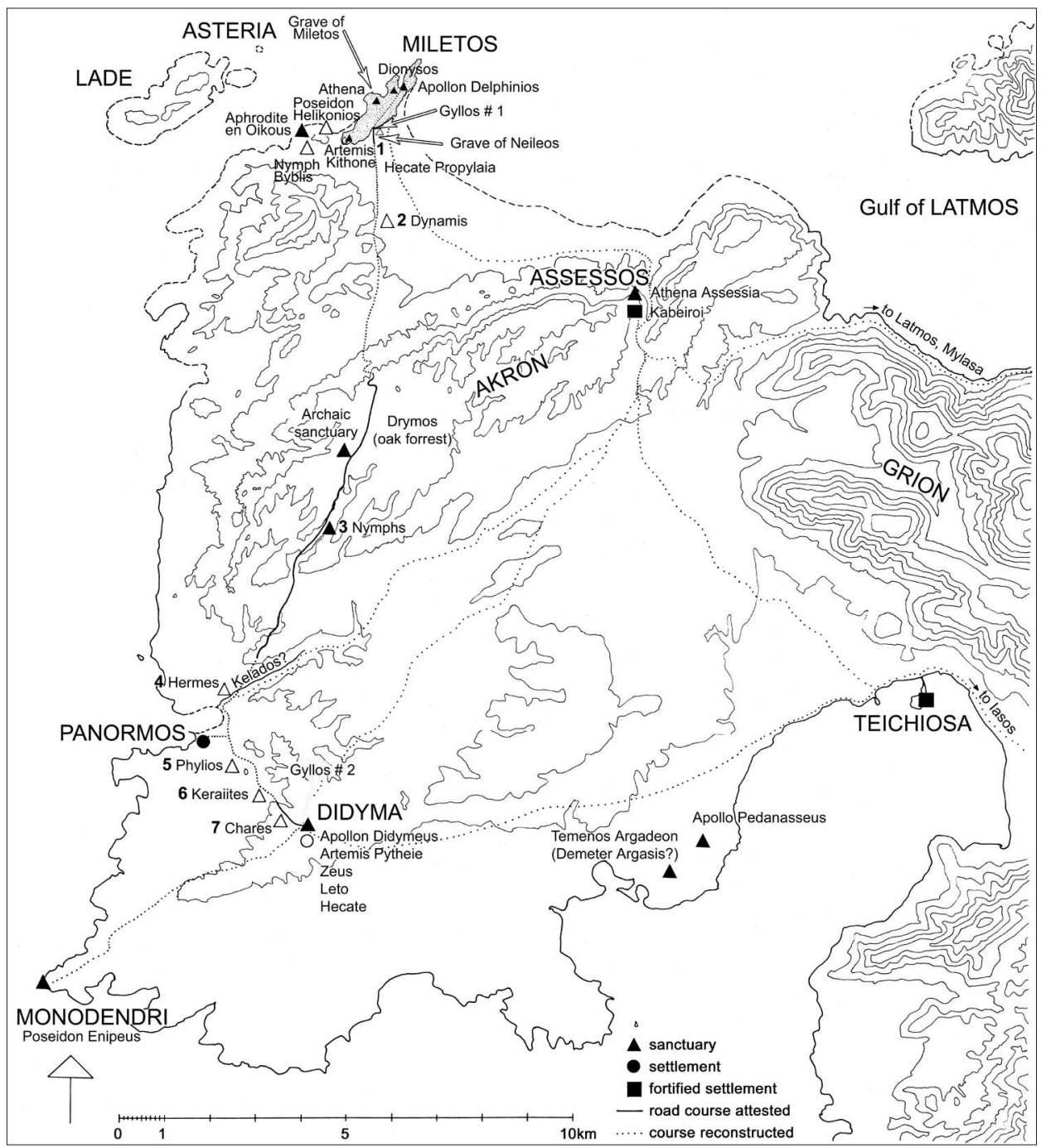

Fig. 20:

Map of Milesia with important cult places and processional road to Didyma (drawing author). altar(?) made of mica-shist and poros blocks, in whose lower step an inscribed marble slab was integrated ${ }^{113}$.

113 Meiggs/Lewis 1969, 3 f. no. 3; Schörner 2007, 21, 42, 84 f., $149 \mathrm{f} ., 212 \mathrm{f}$. A2 figs. 9-14. The upper part of the monument is not preserved as it was demolished when it was overbuilt by a stoa in the $1^{\text {st }}$ century AD. Polignac 1995, 148 n. 55 speaks of a "cenotaph", Jeffery 1990, 300 thought of an altar, Schörner 2007, 212 assumes a third step as plinthe for a statue, stele or some votives. Remarkable is that the marble slab with the inscription does not fit well to the basis made of mica shist and poros. The monument in its present state seems to be a re-arrangement. Also, the inscription was not erected by the polis, but by the sons of a certain Brentes: $\Gamma \lambda \alpha v^{9} \mathrm{O}$

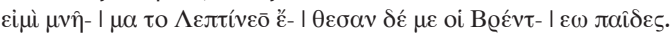
This implies an originally 'private' monument, which was later transformed into a public one, maybe by translocating the stone with the inscription from another place (an extramural cemetery: Schörner 2007, 21 n. 131?) to the agora, where it was integrated into the altar(?). A translocation would lower the date for the erection of

\section{Miletos' many mythical founders, their graves, and the heroon of Neileos}

In Miletos, the situation is more complicated as for example in the much younger colony Selinous. Because of its high age, the city had a whole sequence of founders, beginning with Anax and Asterios in prehistory, Miletos, Sarpedon and Keladon in Minoan times, Herakles and Achilles in Mycenaean times, Nomion, Nastes and Amphimachos in Karian times, and finally Neileos

the inscription on the agora of Thasos. Its dating is therefore only a terminus post quem. 
in Ionic-Greek times. This history was remembered through myths and related rituals located at many places within the territory of the city-state (fig. 20) ${ }^{114}$. In only three cases we have information regarding these founders' graves:

\section{Asterios}

According to Pausanias, the grave of 'autochthonous', earth-borne giant Asterios, son of Anax, was shown on an islet called 'Asteria', situated in the Maeander Bay. It lay close by the famous island of Lade, wherefore Asterios' heroon was located extra-urban. Pausanias, who seems to have visited the site personally, ironically notes the remarkable curiosity that Asterios' corpse was "not less than ten cubits (c. $5 \mathrm{~m}$ ) tall", still too small for a giant in his opinion"115. The background for this story may have been a special attraction, shown to tourist like Pausanias by the locals. One may think of gigantic Miocene marine or animal fossils, the area around Miletos was rich of and which may already have led Anaximander to his theory that humankind was originally stemming from sea creatures. Pausanias knew this theory of Anaximander and alluded to it when discussing giant mammal bones found in the Orontes River ${ }^{116}$. This is not surprising since Anaximander's writings were available in every good library all over the Mediterranean, one has only to think of the sensational find of the catalogue fragment of the $2^{\text {nd }}$ century $B C$ gymnasion-library of Tauromenion-Taormina on Sicily, listing his text ${ }^{117}$.

The island of Asteria can probably be identified with a small $22 \mathrm{~m}$ high rocky hill, only c. $2.5 \mathrm{~km} \mathrm{NE}$ of Miletos, and now embedded in the accumulated sediments of the Maeander. It served as burial ground in Late Osmanic times, from which it got the name 'Mezar Tepe': “Hill of the Graves”"118.

\section{Miletos}

Eponymous heros Miletos, who came to Miletos from Minoan Crete together with Sarpedon, was burried on an island by his son Kelados, who also named the island after his father and settled there ${ }^{119}$. We may assume that the heroon of Miletos was shown somewhere within the old center of the city, around the temple of Athena, where a Minoan and subsequent Mycenaean settlement have been excavated (fig. 1,10$)$. This area may be identical with

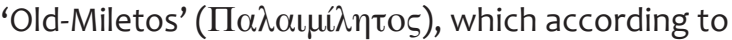
Strabo, citing Ephoros, was founded by Sarpedon

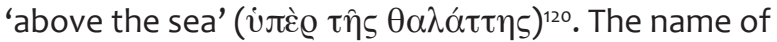
this settlement is mentioned in Hittite texts as Mil(I)awanda or Mil(I)awata, originating perhaps from the Minoan place name Mil(I)atos ${ }^{121}$.

The cult of heros ktistes Miletos, securely attested since the $5^{\text {th }}$ century $B C$, but likely much older ${ }^{122}$, is surprisingly resilient: it is still alive in early Byzantine times $\left(5^{\text {th }} \text { century } A D\right)^{123}$.
114 Herda 1998 (grave of Neileos, Poseidon Enipeus at PosideionMonodendri, Artemis Kithone on Kalabak Tepe); Herda 2006a, 259-385, 436-442, 447-449 fig. 17 (stations of the state procession to Didyma); Herda, 2011, 74 f. fig. 6; Herda forthcoming a (founders of Miletos).

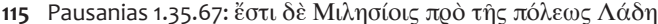

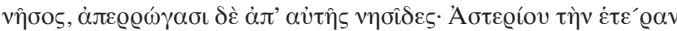

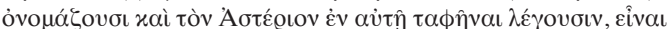

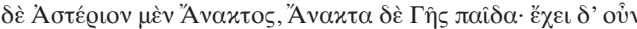

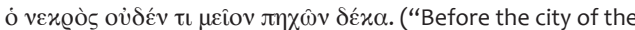
Milesians is an island called Lade, and from it certain islets are detached. One of these they call the islet of Asterios, and say that Asterios was buried in it, and that Asterios was the son of Anax, and Anax the son of Earth. Now the corpse is not less than ten cubits.") Pausanias makes a similar joke about the ash altar of Apollo in Didyma, which, though built by Herakles and since then constantly growing from the blood (and ashes) of the sacrifices, would be quite small for its age: Pausanias 5.13.11; cf. Herda 2006a, 354 f. and 2011, 61 f. n. 22.

116 Mayor 2000, 73 f., $214 \mathrm{f}$. On the fossils found by Roman emperor Tiberius(?) at the banks of the Orontes west of Antioch in Syria, most probably fossiled mammoth bones, see Pausanias 8.29.2-4; Mayor 2000, 73, 293 n. 18. Xenophanes of Colophon, Anaximander's pupil, is directly refering to his theory: Diels/Kranz 21A 33.5-6; cf. Naddaf 2003,38
117 Blanck 1997a; Blanck 1997b, visible is the heading and few letters

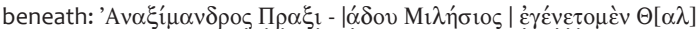
$\varepsilon ́ \omega$; cf. Couprie 2003, 253 n. 220 . Photo techniques like infra-red and ultra-violett would help to make more text readable. This effort is definitely worth it.

118 For Mezar Tepe see: Wilski 1906, map C 3 (“Mesartepe"); Philippson 1936, map ("Mesartepe", 2.5 km W of the Theatre Hill and less then $1 \mathrm{~km}$ north of the small village of "Patniotiko" which is located on the eastern side of ancient Lade); on Asterios see Wernicke 1896; Herda forthcoming a, § 2.1.1 with fig. 2

119 Scholium on Dionysius Periegeta 825

120 Ephorus FGrHist 70 F 127 (= Strabo 14.1.6); cf. Herda forthcoming a, §2.2.3.

121 Herda/Sauter 2009, 57 with n. 41; Herda forthcoming a, § 2.2.4 122 Cf. Herda forthcoming a, § 2.2.1-2.2.2.

123 Cf. the statue of his mother Areia: P. Herrmann in: Herrmann et al. 2006, 244 f. no. 1402, pl. 39; S. Frede in: Bol 2011, 170 XI.9, pl. $94 \mathrm{e}$ (inscription $5^{\text {th }}$ century AD, sculpture possibly older): Mí $\tau \eta$

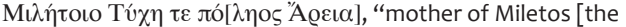
founder, A.H.], Tyche of the ci[ty, Areia]". In the honorary inscription for Vitianus, the Consularis Cariae, the Demos of the city labels itself as “Demos of Miletos' [the founder, A.H.]": Herda 2006a, $308 \mathrm{n}$. 2192; W. Günther in: Herrmann et al. 2006, 81 f. no. 1129, pl. 14 


\section{Kelados}

About Kelados' grave we know nothing. According to the Milesian tradition, his mother was the nymph Doie, a daughter of the rivergod Maiandros. Kelados, or Keladon, the "clamorous", was probably himself an immortal rivergod. This explains also the absence of a grave: there never existed one. Instead, his sanctuary was located close to Panormos, the harbour of Didyma, and formed one of the stops during the Milesian newyears procession to Apollo's oracle since Archaic times at the latest. At Panormos a small river flows into the sea which the Ancients may have identified with Kelados, venerating him as one of the personifications of their successful occupation of and subsequent rooting in the new lands in Asia Minor (fig. 20) ${ }^{124}$.

\section{Neileos}

Most important of all founders, because the most recent, was the Ionian prince Neileos, son of king Kodros of Athens. Surprisingly his grave was not in the agora, but instead, as Pausanias described it, right outside the city gates of Miletos, on the left hand of the processional road to Didyma (figs. 1, $8)^{125}$. The 'Sacred Gate' with the beginning of the extra-urban processional road is located ${ }^{126}$, but the grave is not. Its position outside the city can be explained by assuming that it was originally part of the family grave of the Neleidai, an old Milesian genos tracing itself back to the mythical Ionian founder ${ }^{127}$. The Neleidai still existed in late Hellenistic times, as we know from a Didymæan inscription ${ }^{128}$. They may have acted as basileis, "kings", representing the city in the league of the twelve Ionian cities of Asia Minor, assembling in

124 Scholium on Dionysius Periegeta 825; for Kelados, his sanctuary and the procession see Herda 2006a, 302-310, 448; Herda forthcoming a, § 2.2.2.

125 Pausanias 7.2.6; cf. Herda 1998, 3-10 fig. p. 5.

126 Gerkan 1935, 12-37 figs. 3-14, pls. 1-13 ("das Heilige Tor”). Before the procession started from the Delphinion in Miletos, one Gyllos, a sacred boundary marker, was placed at the Sacred Gate. A second Gyllos was erected "at the doors" of the Apollo-temple in Didyma: Herda 2006a, 249-256 figs. 9, 12, 17, 22; Herda 2011, 74 fig. 6. Close by the Sacred Gate was also located a sanctuary of Hekate (Propylaia, Epiteicheia). It served as first stop during the procession to Didyma: Herda 2006a, 282-289 figs. 9, 12, 17 and 2011, 69 n. 70 figs. 2, 6. 127 Herda 1998, 16-19, $42-47$ and 2006a, 131 n. 911, p. 348

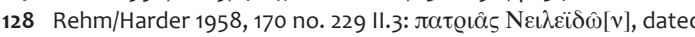
to 66 BC; cf. Herda 1998, 19 with n. 137 and 2006a, 348, 350 n. 2506.

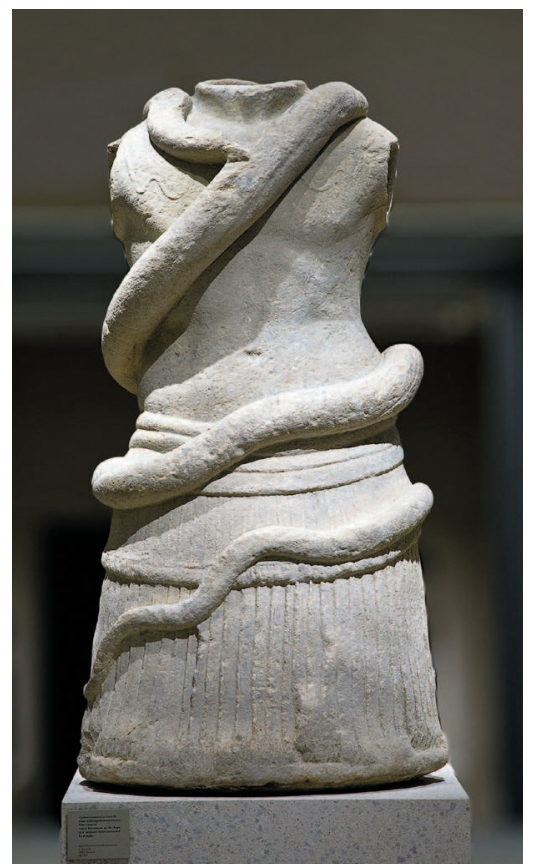

Fig. 21 :

Late Hellenistic

over life size

marble cuirass,

found in 1903

near the Sacred

Gate. Berlin,

Antikensammlung

Inv. SK 1983

(photo Johannes

Laurentius,

Staatliche Museen

Berlin).

the Panionion at the northern foot of the Mykale Mountains from Geometric times on ${ }^{129}$.

The public founder cult at the grave of Neileos is to be expected already in late Geometric times. But the earliest attestation for the cult comes from the Heraion of Samos, where a "priest of Neileos", supposedly the one from Miletos, dedicated a miniature bronze vessel to Hera c. 575-550 BC130.

The position of the Neileos-heroon close to Miletos' main city gate signals an important function the heros fullfilled: that of a protector of the city. One may compare the heroon close to the western city gate of Eretria' ${ }^{131}$. Pausanias describes a similar

129 Herodotus 1.147; Pausanias 7.2; Strabo 14.1.3; cf. Herda 2006b, 51, 61 and 2009, 40 n. 83, 59 n. 168; Herda forthcoming a, § 2.5.4. 130 SEG 28, 716; Herda 1998, 19-22 fig. 1-2; Herda forthcoming a, $\S 2.5 .6$.

131 The family graveyard around a Late Geometric warrior grave became an intramural heroon, when the city was fortified c. 680 BC: Bérard 1970; Polignac 1995, 130-137; Herda 1998, 42-47; Schörner 2007, 206 f., 209-212 (A1) figs. 1-8. However, according to the new city wall reconstruction by Frederiksen 2011, 74 f. 138-142 figs. 33-36, the area of the graveyard remained outside the city wall until the mid $6^{\text {th }}$ century $B C$, excluding the lower plain between the harbour and the acropolis area (in: Ecole Suisse 2004, 26 f., $178 \mathrm{f}$. the existence of a city wall before c. $550 \mathrm{BC}$ is even doubted at all). This is not convincing, as in plot 740 (for the location see Frederiksen 2011, 140 fig. 33) was found a fortification wall of the early seventh century BC, running NW-SE towards the central city area around the Apollo temple: Mazerakis Ainian 1987, 8 f. 12 f. figs. 6, 8 pl. 1, 6; Ecole Suisse 2004, $220 \mathrm{f}$. It suggests that Eretria had a fortification wall including the acropolis and the harbour already in the early 


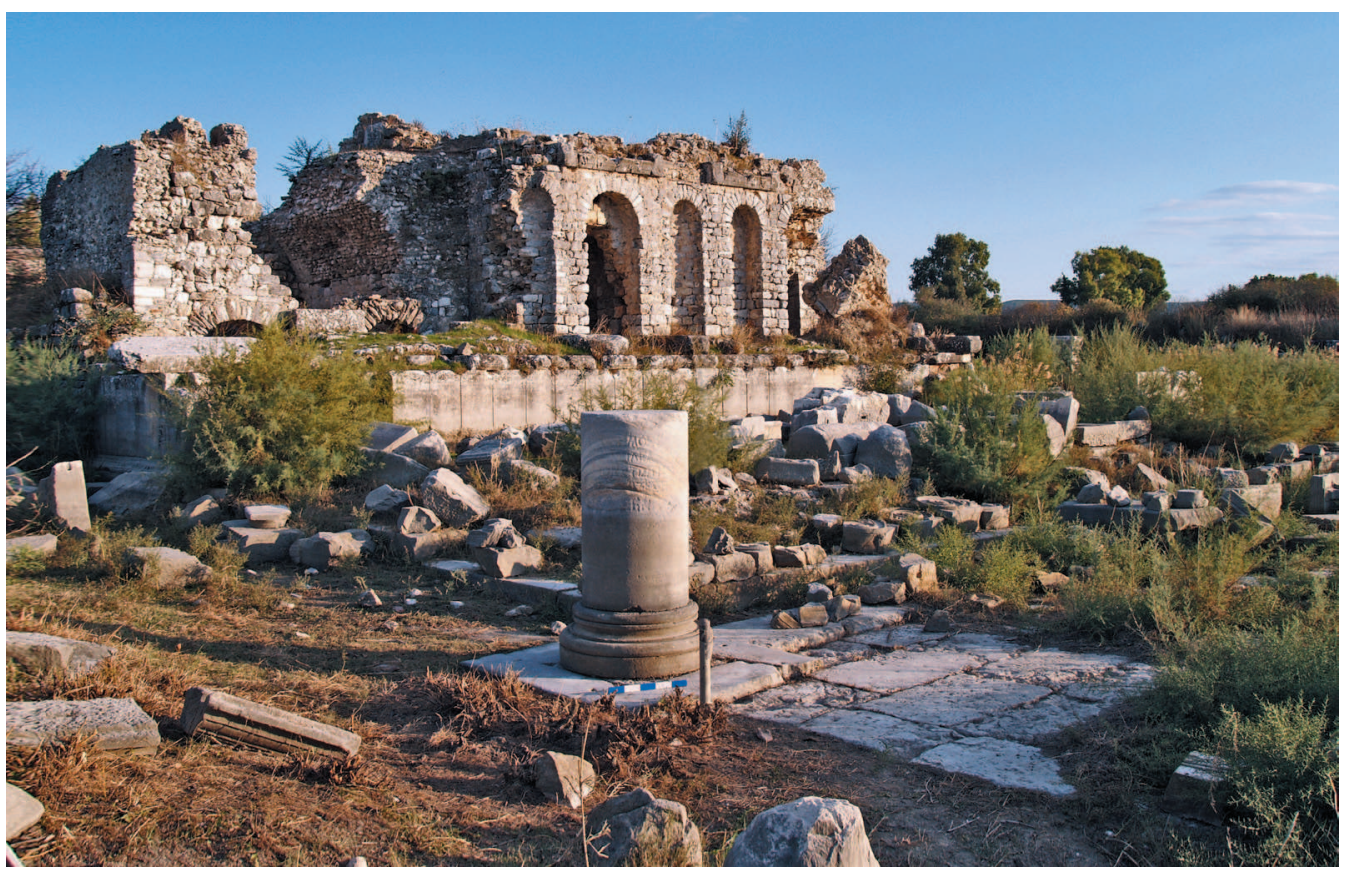

Fig. 22 :

Basis for Neileosstatue in front of nymphaeum, restored in mid- $3^{\text {rd }}$ century AD (photo author 10/2011).

position for the heroa of the founders of two other East Ionian cities, Kolophon and Ephesos. Andraimon and Androklos were, like Neileos, killed in combat with the indigenous Karians. In Ephesos, where the heroon of Androklos was likewise located at the processional road to the Artemision, close to the main city gate, the so-called Magnesian Gate,

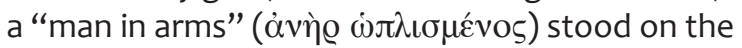
grave ${ }^{132}$. In this manner, the protective role of the heroon was manifest.

Perhaps, the heroon of Neileos in Miletos looked the same. An indication can be bronze coins issued by the city in the Imperial period, depicting her Minoan eponymous heros ktistes Miletos, wearing hoplite armour ${ }^{133}$. A late Hellenistic, over life size marble cuirass, enwinded by a snake and found in 1903 close to the Sacred Gate ${ }^{134}$, may therefore originate from the Neileos heroon (fig. 21) ${ }^{135}$.

$7^{\text {th }}$ century BC. The graveyard at the West Gate was built over by housing in the late $5^{\text {th }}$ century BC, after Athens had subdued Eretria in $424 \mathrm{BC}$. The reason may have been that the hero cult had ceased to exist after the conquest by the Persians in $490 \mathrm{BC}$ or only in 424 . 132 Andraimon: Pausanias 7.3.5; cf. Herda 1998, 44. Androklos: Pausanias 7.2.9; cf. Herda 1998, 6 f.; for the assumed location cf. Herda 1998, 6 with n. 31; Sokolicek 2009, 328.

133 Herda 2006a, 308 n. 2192; Herda forthcoming a, § 2.2.1.

134 Rabe 2008,186 no. 61 pl. 62.

135 Cf. Herda forthcoming a, § 2.5.6.
Nevertheless, the city of Miletos was also not willing to abstain from Neileos in the city center, where the cult of a Greek heros ktistes was traditionally located: but instead of a heroon, a statue was erected for the founder in the agora, in front of the Roman nymphaeum and opposite the Hellenistic bouleuterion. This place was quite prominent in the Roman period ${ }^{136}$. The lower basis of the monument survived with a mid- $3^{\text {rd }}$ century $A D$ inscription on a column drum, mentioning that the statue on top, now lost together with its basis, had been "restored" ( $\dot{\alpha} \tau о \varkappa \alpha \tau \dot{\varepsilon} \sigma \tau \eta \sigma \varepsilon v)$ by the Milesian demos (figs. 2, 7; 22). The term implies the repairing of an older monument, perhaps also a statue ${ }^{137}$. It reminds us of the restored statue of the heros C. Iulius Epikrates in one of the gymnasia of Miletos, which had been affected by fire (see $\S$ II).

The honorary statue of Neileos in the agora obviously did not form part of a large-scale heroon, but it could definitely have served his cult: sacrifices

\footnotetext{
136 For this part of the agora: Cain/Pfanner 2009.

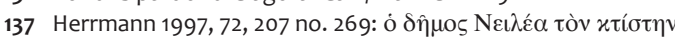

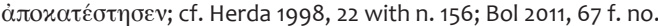
III.4.1 fig. 31, pl. 27h; Herda forthcoming a, § 2.5.6; for the exact position compare: Cain/Pfanner 2009, 91-92 fig. 11. Because of the deviation of the basis from the orthogonal street-insula-grid as well as the closeness to the NW-corner of the Nymphaeum they assume the monument to be older than the Nymphaeum (late $1^{\text {st }}$ century $\left.A D\right)$.
} 
in front of the statue may have taken place during certain public festivals, converting it into a temporal cult statue ${ }^{138}$.

\section{The heroon of Thales, act 2: On Thales as first of the Seven Sages and 'cultural hero', where his heroon was located, and how it looked}

But back to Thales now: The story given by Plutarch delivers the additional information that Thales had

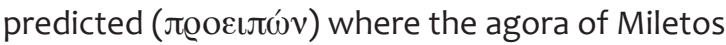
would be one day. I think, this story does not serve simply to demonstrate the philosopher's ability to predict what happens in the future ${ }^{139}$. Instead, Thales did not foresee this by accident: As it was exactly in his lifetime, that the street-insula-grid system was introduced in his hometown (fig. 19), it seems only logical to assume his participation in the plannings.

Thales as founder of Ionian natural philosophy, or better to say, natural sciences as a whole, had many skills: He himself brought geometry and astronomy from Egypt, measuring the height of the pyramid with the help of its shadow ${ }^{140}$. It is also possible that he saw there samples of regular town

\footnotetext{
138 Compare statues of gods and emperors in Roman agorai. The best indicator for a cult statue is the presence of an altar: Witschel 1995, 361-367, esp. 365 n. 40. The altar where the Milesians sacrificed to Neileos intra muros may have been a portable one, placed in front of the statue. Otherwise the large foundation in the middle of the square between Nymphaeum, Bouleuterion and Market Gate may have served as altar: Cain/Pfanner 2009, 87-92 figs. 6, 8-11. Another opportunity is given, when we take the 'Ehrengrab' in the court of the bouleuterion as an altar (of Artemis Boulaia, Apollo Didymeus, Zeus Boulaios) (see above § II): One figure on the frieze has been interpreted as depiction of Tyro, the mother of Pylian Neleus, the very forefather of the Neileos and the Neleids: Th. Wiegand in: Knackfuß 1908, 88 pl. 16, 2; Schollmeyer 2011, 21 f. with n. 194; p. 23 II.3 pl. 2b. On Tyro see Herda 1998, 14. The Neleidai (= Milesians) are also mentioned in the honorary inscription for Lichas, which was erected in the propylon of the Bouleuterion right opposite the statue of Neileos: C. Fredrich in: Knackfuß 1908, 115-117 no. 12, I. 7: छuvò

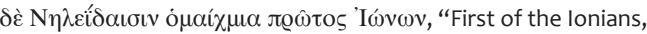
you elected the tribes of the Cretans as allies for the Neleidai"; cf. Herrmann 1998, 158 n. 12; cf. Herda 1998, 22 f. n. 155; see above n. 49.

139 So e.g. Classen 1965, 931.

140 Diogenes Laertius 1.27; Aetius 1.3.1; Proclus in Euclidem 1.26 p 352 Friedländer; cf. Herodotus 2.109; Kirk et al. 2001, 93 f. on nos. 79-80; Hahn 2001, 57-61; Hahn 2003, 73 f.
}

planning, as the Egyptians practiced since the early $I^{\text {nd }}$ millenium $\mathrm{BC}^{141}$.

Furthermore, Thales had the practical skills of a hydraulic engineer: Herodotos describes how he mastered the river Halys, which hindered the Lydian king Kroisos and his army from advancing against the Persians C. 547 BC: He channeled it in two streams, which were smaller, and by means of this facilitated Kroisos' army to cross over ${ }^{142}$. Water also played an essential part in Thales' cosmological ideas, which were likely influenced by Egypt - or at least in concert with them since life in Egypt was indeed the gift of the Nile ${ }^{143}$. The importance of water is already present in Homer's and Hesiod's cosmological picture. They declared the "river Okeanos" as the origin of all things and even of the gods and men ${ }^{144}$. In the famous description of the shield of Achilles, Homer also delivers the first abstract model of the kosmos, the existing world in its given order ${ }^{145}$. Hephaestus, the divine smith, artfully incises the picture onto the round shield, producing the first 'world map': The earth (Gaia) is slightly vaulted, disc-shaped, consisting of several 'rings', picturing human life on the occupied land (oikumene) in several scenes. The earth is surrounded by the sky (Ouranos), the stars, the moon and the sun (in this order). Okeanos forms the outermost 'ring" ${ }^{\prime 46}$. From this model Thales deduced his prime theory that water is "the principle of all" (arche) and that "the earth lies on water" 147 . Via Thales' teaching, Hephaestus' map also got the archetype of Anaximander's and Hekataios' maps of the world ${ }^{148}$.

141 C.f. Castagnoli 1971, 57-59 figs. 22 (Kahun, village for workers of the pyramid of Sesostris II, C. 1897-1879 BC), 23 (Tell-el-Amarna, city of Akhenaten, 1396-1354 BC), but without any reference to Thales.

142 Herodotus 1.75; cf. Hahn 2001, 56, 254 nn. 50 f.

143 Cf. Haider 2004, 468-470.

144 Homer, Iliad 14.246 (all things, implicating also of all gods and men: Nagy 2011b, 267), 14.201, 302 (all gods) and Hesiod, Theogony 337-388 (river gods and nymphs).

145 Philipp 1984, 3 f.; Herda 2012.

146 Homer, Iliad 18.478-609; cf. Hardie 1985; Nagy 2011b, 268 $276,594-599$. It is difficult if not impossible to translate Homer's description into a two-, or even three-dimensional picture, but he must have had Phoenician metal bowls with concentric friezes in mind, when creating his shield of "unattainable complexity", see Snodgrass 1998, 40-44 fig. 17. One of the best and most convincing attempts in arranging the concentric circles is given by Philipp 1984 (however without figure and very concise). Recent bibliography and further commentaries in: Aion 31, 2009. The reconstruction ibid. (Cerchiai 2009, 24 fig. 1) is misleading.

147 Aristotle, Metaphysica 1. 983b, 6-24 (= Diels/Kranz 11 A12)

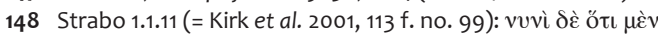

"O 
Maybe Thales' insights were at least partly provoked by his observation of the dynamic palæogeographic development of Miletos which, as a harbour town, had always been exposed to the impact of water. The constant change of landscape, resulting from tectonics of the Maeander graben as well as the sedimentation activity of the Maeander river, caused the rise or decline of the sea level, transforming land into sea and vice versa ${ }^{149}$. Thales' special achievement is that he first identified the causes of these natural processes and successively developed methods to influence them to the advantage of humans, e.g. by involving hydraulic engineering 150 . This is the message in the Kroisosstory as well as in that of Thales choosing the location of his own grave, later to be his heroon.

Thales' ideas are further developed in the theories of his contemporaries and successors: Anaximander, his most important pupil, exchanged water as the principle of all being by the apeiron, the "Boundless/Infinite", and postulated an alternate drying out of the sea by the sun, followed by a flooding, arguing with the existence of marine fossils in inland sites ${ }^{151}$. Anaximenes, pupil of

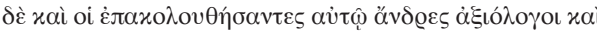

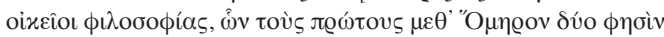

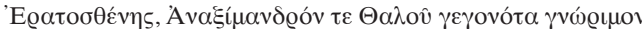

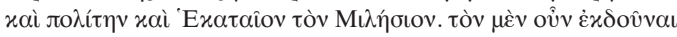

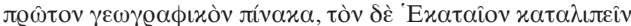

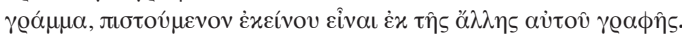
"What we have already advanced is sufficient to prove Homer the father of geography. Those who followed in his track are also wellknown as great men and true philosophers. The two immediately succeeding Homer, according to Eratosthenes, were Anaximander, the disciple and fellow-citizen of Thales, and Hecatæus the Milesian. Anaximander was the first to publish a geographical chart. Hecatæus left a work [on the same subject], which we can identify as his by means of his other writings." (transl. H.C. Hamilton). As Eratosthenes (c. 276-194 BCE) was the head of the library of Alexandria, he likely had access to the maps of Anaximander and Hekataios. So will have had Herodotus C. 200 years earlier in Athens, when he ridiculed the maps showing a flat discoid world, still the dominant imagination in his time: Herodotus 4.36; Kirk et al. 2001, 113 f. no. 100; Naddaf 2003, 34, 63 n. 87, 54 fig. 1.1; Couprie 2003, 196 fig. 3.16; Hahn 2010, 153.

149 Müllenhoff et al. 2009a, 106. On the harbours of Miletos see Brückner et al. forthcoming.

150 One may compare the contemporaneous efforts of Greek engineers to ensure the water supply of cities, for example the tunnel of Eupalinos of Megara in Samos (Kienast 1995; Hahn 2001, 114-116; most lately Olson 2012), the water system of Athens (TölleKastenbein 1994) or the 'krene of Theagenes' in Megara (Hellner 2004). At that time, Miletos seemed to have run her water supply only by ground water wells and small water pipelines: Tuttahs 2007, 5, $67 \mathrm{f} ., 74 \mathrm{f}$.

151 Aristotle, Meteorologica B1, 353b6; cf. Kirk et al. 2001, 151-156 on nos. 132-137: see above $\S$ VI.1 with n. 116 on the (fossilized?) bones of the giant Asterios near Miletos.
Anaximander, explained water, earth and stones as differently compacted forms of the principle cosmic material, air, which constantly changes its condition of aggregation ${ }^{152}$. Xenophanes of Kolophon thought of a periodical mixing of earth and water, being the reason for the growing and decline of living species, finally resulting in a total dissolution of earth in water. Like Anaximander, he argued with the appearance of fossils ${ }^{153}$. Herakleitos of Ephesos instead believed the cosmic fire to be the true reason for the transformation of earth into water ${ }^{154}$.

Thales' competence in political matters is to be mentioned, too. He advised the Ionians to build a common assembly hall, a bouleuterion, in the city of Teos in the middle of Ionia for that they could better concentrate their political and military power against the Lydians and Persians ${ }^{155}$. Therefore, he may very well have participated not only in the implementation of the orthogonal gridsystem in the beginning $6^{\text {th }}$ century, but also in the enlargement and reorganisation of the Milesian agora around the mid- $6^{\text {th }}$ century, creating a space suitable to the demands of the growing body of citizens taking part in the political decision-making. With the help of arbitrators from Paros, Miletos had at that time managed to suppress a severe civil strive and had installed a moderate oligarchy which was in good terms with the new dominant power in Asia Minor, the Persians. The growing body of proud and wealthy polis citizens engaged in politics could be responsible for the development of the agora

152 Kirk et al. 2001, 158-162 on nos. $140 \mathrm{f}$.

153 Hippolytus, Ref. 1.14.5-6 (=Kirk et al. 2001, 193 no. 184); cf. Kirk et al. 2001, 192-195 on nos. 181-185 and p. 153 on Anaximander; Naddaf $2003,38$.

154 Herakleitos, fr. 31 (= Clemens, Strom. 5.104.3+5 = Diels/Kranz 22 B 31); cf. Kirk et al. 2001, 216-218 on no. 218.

155 Herodotus 1.170 (= Diels/Kranz 11 A 4); cf. Naddaf 2003, 31 (he mixes up the Ionian city of Teos with the island of Telos; but on p. 35 he correctly has Teos!). Gorman 2001, $125 \mathrm{f}$. unnecessarily doubts the historicity of Thales' proposal. The statement of Socrates in Plato's Hippias maior 281C3-D8 that most of the earlier philosophers, e.g. Pittakos, Bias, Thales, did not take part in politics is pure irony to ridicule the sophist Hippias, being politically very active. Compare Diogenes Laertius 1.23 where it is said that Thales was first involved

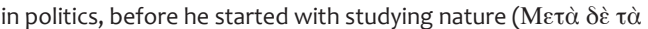

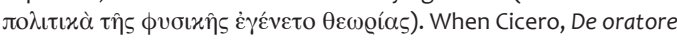
3.137 declares that all of the Seven Sages were leading politicians in their polis states, with the exception of Thales (hi omnes praeter Milesium Thalen civitatibus suis praefuerunt), this does not exclude that Thales was politically active. Cicero only says that Thales was not the leading magistrate of the Milesian state, who was called aisymnetes-stephanephoros since the later $7^{\text {th }}$ century BC, cf. Herda 2005, $289 \mathrm{f}$. and 2011, 60-62 on the eponymous office. 
and lots of other construction projects, such as the Delphinion ${ }^{156}$.

For this reconstruction I can refer to a very reliable source: the Athenian comedian Aristophanes. In the year $414 \mathrm{BC}$ he parodied in his comedy Birds the Athenian geometrician and astronomer Meton of Kolonos alias Hippodamos, who wanted to "measure out the air" to build 'Cloudcuckooville', the new city of the birds, round in shape with an inscribed square and an agora in the centre, to which straight streets from every direction lead. For this achievement Aristophanes

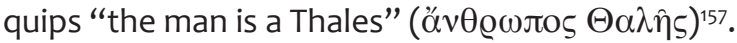
This saying is no exaggeration: The map scetched by Meton is a perfect copy of Anaximander's cosmological map of the world with the inhabited zone (oikumene) of squared shape in the center ${ }^{158}$, adjusted to the scale of a single polis state. Anaximander himself, who is said to have introduced the gnomon as important instrument for defining geographical North and producing a seasonal sundial'59, lastly grounded on Thales' theories, who combined Homer's map of the world placed on the shield of Achilles, with Egyptian and Babylonian knowledge ${ }^{160}$. Additionally Robert Hahn has shown how closely Thales and Anaximander were connected to the theories as well as practices of contemporaneous architects whose creative work not only included the outline of buildings, but also the layout of whole cities according to social and meteorological preconditions, as it was the case with later 'architects' like Hippodamos or Pytheos ${ }^{161}$.

The recognition Thales had gained as a kind of 'cultural founder', respectively hero of Miletos, is

156 Herodotus 5.28 f.; cf. Gorman 2001, 52, 110-113, 118, 120 (early $7^{\text {th }}$ century BC); Naddaf 2003, 29 f. (after 546 BC); Herda 2005, 292 (before $560 \mathrm{BC}$ ); Herda in preparation.

157 Aristophanes, Birds 1009; for Aristophanes' comparison Meton/ Hippodamos/Thales see ingeniously Haselberger 1999. Another comparison of a person with Thales is found in Aristophanes, Clouds 180 (geometry). For Meton of Kolonos cf. Philochoros FGrHist $328 \mathrm{~F}$ 122 with commentary; Hübner 2000.

158 For Anaximander's map cf. Couprie 2003, 194.

159 Diogenes Laertios 2.1 (= Diels/Kranz 12 A 1); cf. Hahn 2001, 61, 206 f. fig. 4.12, 255 n. 70; Naddaf 2003, 52 (taken over from the Babylonians via the Egyptians); Hahn 2010, 145-176.

160 Couprie 2003, 195-201 figs. 3.16-19; see above with nn. 145-148. Philipp 1984, 2 f. assumed convincingly that it was already Homer and his Ionian contemporaries who adopted Babylonian models like the famous map of the world from $7^{\text {th }} / 6^{\text {th }}$ century BC Sippar, today in the British Museum (BM 92687): Gehrke 2007, 22 f. figs. 4-5. 161 Hahn 2001; Hahn 2003, Hahn 2010; on Hippodamos as townplanner, meteorologist and social utopist see Hellmann 2001; Herda in preparation; on Pytheos as omnipotent sculptor, architect and townplanner see Herda forthcoming b, § 6.3. reflected in the anachronistic myth that he came to the town from "Phoenicia", joining lonian heros ktistes Neileos ${ }^{162}$. The story, given in Diogenes Laertius' Lifes of Eminent Philosophers, is a complete construct, mixing up the facts ${ }^{163}$. Thales was no 'Phoenician' in the literal sense. Instead he was a meixobarbaros, of half Karian, half Greek offspring: His father Examyes bears a clear Karian name, while his mother Kleobouline descended from one of the oldest Milesian aristocratic families, the Thelidai. This clan traced themselves back in the time before the Ionian colonization and claimed Kadmos and Agenor, 'Phoenician' princess in Boeotian Thebes, for their ancestors ${ }^{164}$. Their descendants, not Thales, came to Miletos joining Neileos' colonization adventure some four hundred years before Thales was born ${ }^{165}$. Also, they did not come from Phoenicia, but from 'Phoenician' Kadmeia-Thebes. By making Thales a companion of Neileos, the most important of all founders of Miletos, the tradition obviously stressed his role as a heros ktistes ${ }^{166}$.

His recognition culminates in his alledged victory in the Panhellenic competition of the Seven Sages ${ }^{167}$. This story must have spread already shortly after his death, because Hipponax of Ephesos

162 On Neileos and the Ionian migration see Herda 1998 and 2009, 28, 33-41, 91; Herda forthcoming a, § 2.5.

163 Diogenes Laertius 1.22 (= Diels/Kranz 11A1).

164 Cf. Herodotus 1.170 (Thales is a "Phoenician"), 5.57 f. (the Kadmeioi of Thebes are "Phoenicians"); cf. Herda 2009, 77 with n. 284 f., 79 with nn. 300 f.; Herda/Sauter 2009, 77 f., 105; Herda forthcoming $b, \S \S 5,6.5$.

165 According to the Hellenistic Marmor Parium (IG XII 5, $444=$ FGrHist 239, 38; 264/3 BC), the Ionian Migration started 1086/85 or $1076 / 75$ BC; cf. Herda 2009, 28; Herda, forthcoming b, § 2 with nn. $11 \mathrm{f}$.

166 The anachronistic combination of Thales with Neileos in Diogenes Laertius 1.22 may be stimulated by the wording of Thales dedication of his winner price in the Seven Sages-contest to the Apollo Didymeus in Didyma or Apollo Delphinios in Miletos, also cited by Diogenes Laertius 1.29, refering to Callimachus, lambus 1

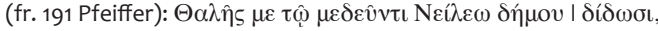

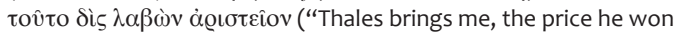
twice, to the lord of Neileus folk"). Instead, Kirk et al. 2001, 84 f. on no. 62 let the couple of Neileos and Agenor arrive in Miletos, as the name of Neileos companion is not mentioned in Diogenes Laertius 1.22 (cf. Classen 1965, 930 who thinks not of Agenor alone, but of the Thelidai as family). That Agenor was rewarded with Milesian citizenship by publishing his name on a citizens list inscribed in stone

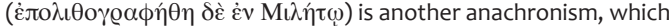
would better suit to Thales' time or even later (the preserved citizen lists, written on the stone walls of the Delphinion, are Hellenistic). That Neileos was expelled from Phoenicia/Thebes together with

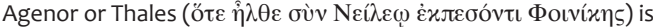
attested nowhere else in the Ionian migration myths. Instead he came either directly from Pylos, or via Athens: Herda 2009, $33 \mathrm{f}$.; Herda forthcoming a, $\S 2.5 .2$.

167 Diogenes Laertius 1.27-33. 
(akme c. 540 BC) refers to $\mathrm{it}^{168}$ and the concept of the Seven Sages, itself an Indo-European legacy ${ }^{169}$, was propagated by the oracle in Delphi in the late $6^{\text {th }}$ century BC. At that time the different home cities started to build up hero cults, to occupy their own sages and profit from their fame ${ }^{170}$. The myth of the competion therefore delivers the 'mythicoritualistic' background for the late Archaic cult of the Sages in their hometowns. We know of a heroon of Bias in Priene, called Bianteion. It also functioned as prytaneion and because of this should have been located close to the agora or in the agora of Archaic Priene, later to be relocated together with the whole city ${ }^{171}$. As the cult of heroes also included large-scale sacrifices with following dining (thysiai), a prytaneion, designed to house such ritual feastings, formed an ideal location ${ }^{172}$.

The heroon of a third member of the Seven Sages, Chilon, is known in Sparta ${ }^{173}$. And already mentioned was the cremation of Solon, following the tradition of the Homeric heroes. His ashes were scattered around Salamis, the island he had won for Athens ${ }^{174}$. This tradition implies a hero cult, but not

168 Hipponax frr. 4, 63, 123 (West), see below with n. 178. Alcaeus fr 448 Lobel/Page (= Himerios, Orationes 28.7 Colonna) may already refer to the story of the Seven Sages. Xenophanes (Diels/Kranz 21 B 19) stresses Thales' astronomic achievements as Heraclit did (Diels/ Kranz 22 B 38): Classen 1965, 931. According to Diogenes Laertius 1.22, quoting Demetrios of Phaleron (c. 350-280 BC) in his List of Archons, Thales was the first to be called 'Sage' in the year of the Athenian Archon Damasias (Olympiade 49.3 = 582 BC), exactly

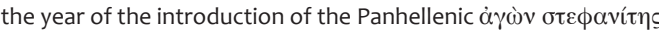
in Delphi: Marmor Parium, IG XII 5, 444 ep. 38 (= FGrHist 239, 38); Eusebius Chronicle p. 125. Kirk et al. 2001, 84 n. 1 assume that Damasias was the first who 'canonized' the Seven Sages. 169 Martin 1993, 121-123; Janda 2005, 300 f. But Martin 1993, 121 alludes besides the Seven Rsis of the Sanskrit Veda (c. 1000 BC) also to the seven wise men building the walls of Uruk in the II ${ }^{\text {nd }}$ millenium BC epic of Gilgamesh.

170 Martin 1993; Christes 2001; Tell 2007, 258-260, 271 171 Diogenes Laertius 1.85, 88; on the relocation of Priene: Herda 2009, 61 n. 175; p. 66 with n. 210: Herda forthcoming b, § 6.3. The transfer of a hero cult in case of a city's relocation is attested for Themistocles C. 400/399 BC, who had a heroon in the agora of old and new Magnesia on the Maeander. Before the transfer of his heroon, perhaps already shortly after his death in $459 \mathrm{BC}$, his bones had been brought to Athens, where he got a heroon in the Piraeus: Thucydides 1.138.5; Diodorus 21.58a; Plutarch, Themistocles 32.3; Pausanias 1.1.2; Nepos, Themistocles 10.5; cf. Malkin 1987, 223-228; Krumeich 1997, 72 with n. 176.

172 Miller 1978, 4-13, 130 (dining, xenia), 17 (heroes in prytaneia), Ekroth 2002, 183. On dining in the Milesian prytaneion, otherwise called Molpon, which was located in the Delphinion: Herda 2005, 249 f., 263-268; Herda 2011, 68 f.

173 Pausanias 3.16.4 mentions the grave on his way from the building named 'Chiton', where the sacred chiton for Apollo Amyklaios was woven, to the city gate, leading to Amyklaia. 174 Aristotle fr. 392 R; Diogenes Laertius 1.62; Plutarch, Solon 32.4 so much as one of the Seven Sages than as heros ktistes of now Athenian Salamis, protecting the cities claim on the island for all times ${ }^{175}$.

Where do we have to look for the heroon of Thales? As stated above, its location is likely to be placed within the limits of the agora extensions of the $6^{\text {th }}$ century BC. Recent geoarchaeological research has shown that these extensions were made not only in the southern fringes of the Lion Harbour, but also in the area of the Hellenistic South Market, including parts of the former Theatre Harbour in the West and of the Eastern Harbour (fig. 18). Theoretically speaking, the available space was therefore quite large. Nevertheless the analysis of the urban development in Late Archaic and Early Classical times does point to the region between the Delphinion in the East, the sanctuary of Dionysos in the Northwest and the Archaic insulae west of the Hellenistic bouleuterion. In this triangle was also found the only in situ inscription of the $5^{\text {th }}$ century BC so far, a banishment decree of the polis, characterizing this part of the town as the political agora of post-Persian Miletos, a suitable place for a heroon ${ }^{176}$. The Late Archaic-Classical Delphinion, including the Molpon-prytaneion, is only $60 \mathrm{~m}$ away. It was in this very sanctuary that Thales dedicated the price he had won in the competition of the Seven Sages, at least according to one version of the story. On the golden bowl of the Arcadian Bathycles he is said to have placed the following prose inscription, which quite matches the standard form of Archaic dedications, though it scarcely has survived the Persian conquest and following plundering of Miletos ${ }^{177}$ :

175 Farnell 1921, 361; Malkin 1987, 83, 218; see above § III with n. 81. 176 Cf. von Gerkan 1922, 41 f. figs. 53 f.; A. Rehm in: von Gerkan 1922, 100-104 no. 187 fig. 98 pl. 12 f.; Herrmann 1998, 197 n. 187 pl. 15, 1; Gorman 2001, 230-234; Herda 2005, 272 f. fig. 25. The decree is now redated to shortly before the Persian conquest of $494 \mathrm{BC}$ by Slawisch 2011; I will refer to her unconvincing arguments in: Herda in preparation.

177 Diogenes Laertius 1.29. According to other versions, Thales dedicated the price, a tripod, or golden cup or bowl, to Apollo Didymeus in Didyma: Maeandrius FGrHist 492 F 18 (= Diogenes Laertius 1.28-29, 32); Callimachus, Jamb. 1 fr. 191 (Pfeiffer); Diegesis 6.10-19; cf. Herda 1998, $22 \mathrm{f}$. on both versions and the wording of the dedications. The text, Kerkhecker 1999, 42 n. 196 gives for the prose inscription, is wrong: the addressee is Apollo Delphinios, not Didymeus, see Diogenes Laertius 1.29. The metric inscription, Diogenes Laertius also gives in 1.29, does not specify Apollo (see above n. 166). But Diogenes adds that Thales "send it to Apollo at

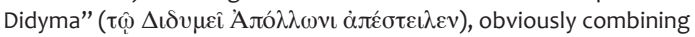
two contradictory versions. 


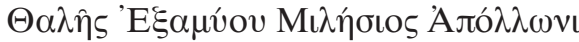

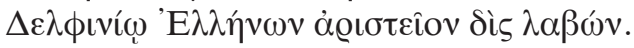

"Thales the Milesian, son of Examyes [has dedicated this] to Apollo Delphinios, after twice winning the price from all the Greeks."

[transl. R.D. Hicks]

Perhaps this wording is only a later forgery, but the Bathycles story itself is parodied already by Thales' $6^{\text {th }}$ century BC 'neighbour', the poet Hipponax of Ephesos, who was himself parodied by Callimachus (c. 310-240 BC) in his first lambus, letting him narrate the story a second time ${ }^{178}$. Callimachus' Hipponax gives another striking detail of the story: When Bathycles' son Amphalces brings Thales the golden bowl for the first time, he finds him in the Apollo sanctuary in Didyma, deep in geometrical studies, more concrete, developing his theorem that any angle, inscribed in a semicircle, is always a right angle ${ }^{179}$. But the discovery is here attributed to the "Phrygian Euphorbus", who anybody in the audience knew as being the earlier incarnation of Pythagoras. Callimachus thus (ritually) ridicules two sages alike, Thales and his pupil Pythagoras, but in the same time he hints at a quite serious aspect, that of the origin of all human wisdom. As E.A. Schmidt and A. Kerkhecker have ingeniously pointed out, Euphorbos is finally to be identified with Apollo. Therefore does Thales' (or Pythagoras') theorem as well as his wisdom go back to Apollo himself, the god of $\sigma o \phi i \alpha^{180}$. The sage is an instrument of the god. As such he can, as any other sage, be venerated as a hero, even though, only after his death and for an achievement which is not his alone, at least in the eyes of Delphi' ${ }^{181}$.

Regarding the heroon of Thales in the agora of Miletos we have some further informations.

178 Hipponax fr. 4 (West), cf. frr. 63 and 123, where he refers to the

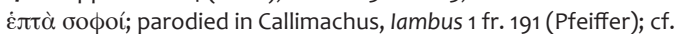
Kerkhecker 1999, 29-44, esp. 30: "This line is not original Hipponax, but Hipponactean pastiche. The concentration of mannerism is too good to be true. Callimachus parodies the father of parody,

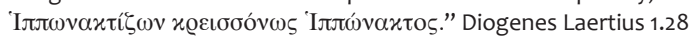
instead cites the local historian Maeandrius/Laeandrius of Miletos (FGrHist 492 F 18) as model for Callimachus' Bathycles story. 179 Callimachus, lambus 1 fr. 191.58-61 (Pfeiffer). The geometrical diagrams illustrating the four theorems of Thales can be found in: Hahn 2001, 58 fig. 2.2.

180 Schmidt 1990, 126 f.; Kerkhecker 1999, 42-44; Herda 2012. 181 In one of the versions (Diogenes Laertius 1.28), the oracle of Apollo in Delphi itself is initiating the competition of the most wise man.
Diogenes Laertius resp. his source witnesses an honorary statue, erected for Thales and bearing the following inscription ${ }^{182}$ :

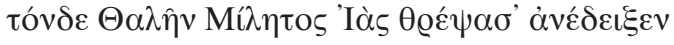

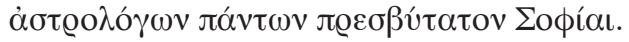

\section{"Ionian Miletos brought up Thales, and dedicated him, oldest of all astronomers, to Sophia."}

The statue was obviously a portrait statue. Perhaps the unnamed bearded head in the Vatican, Galleria Geografica, Inv. 2892, arranged with that of Bias of Priene in a double herm, belongs to the Milesian statue (figs. 23a-b) ${ }^{183}$. The style of the head would date it to the $4^{\text {th }}$ century BC, long after Thales had died. In consequence it could only be a posthumous product of phantasy, no correct physiognomic rendering of the sage, as during his lifetime portrait sculpture was never realistic in the sense of physiognomic reliability ${ }^{184}$. The late Classical statue, presumably in a seated pose, typical for portraits of philosophers ${ }^{185}$, may well have been added to the older heroon as an honorary statue, erected by the city of Miletos. According to the inscription the statue was dedicated not to Apollo, but to the goddess of "Wisdom", Sophia'186.

182 Diogenes Laertius 1.34 (= Diels/Kranz 11 A 1.34).

183 Richter 1965, I 81-83 esp. 83 fig. 321-322; Heintze 1977, pls. 44, 2; 45, 3; Richter/Smith 1984, 209 f. fig. 172. H. Heintze (Heintze 1977, pls. 44.1, 45.1-2) wants to count an over life-size bearded head in a private collection for a portrait of Thales, but this is only hypothetical.

184 Richter 1965, I 81; see Fittschen 1988, 2-5 on 'idealized' and 'individualized portraits'. Compare the statue of Chares and other seated statues of Milesian aristocrates along the sacred road between Miletos and Didyma: they are idealized portraits, representing certain types (men as aristocrats, participating in seated ritual dining; women depicted as sitting in the aristocratic oikos and 'ruling' over it), without clear signs of individuality of the depicted persons. This is only given by the name inscriptions, e.g. that of Chares: Herda 2006a, 332-342.

185 All the portraits of the Seven Sages, especially those in a group composition, repeated in Roman mosaics and wall paintings, show them seated. A seated (and unbearded!) Thales is depicted in the wall painting from the 'Palazzo dei Cesari' in Ostia from Hadrianic times: Richter 1965, I 81, 83 fig. 325; Richter/Smith 1984, 209 fig. 171.

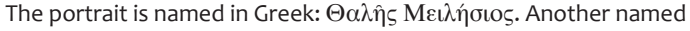
portrait is a bearded bust on a mosaic from Baalbek, of the $3^{\text {rd }}$ century AD: Richter 1965, I 81 no. 4 fig. 314; Richter/Smith 1984, 197 f. no. 4 fig. 158.

186 The goddess Sophia is first personified in Classical poetry (e.g. Euripides, Medea 843), depictions are attested from Hellenistic times on: Xagorari 1994 

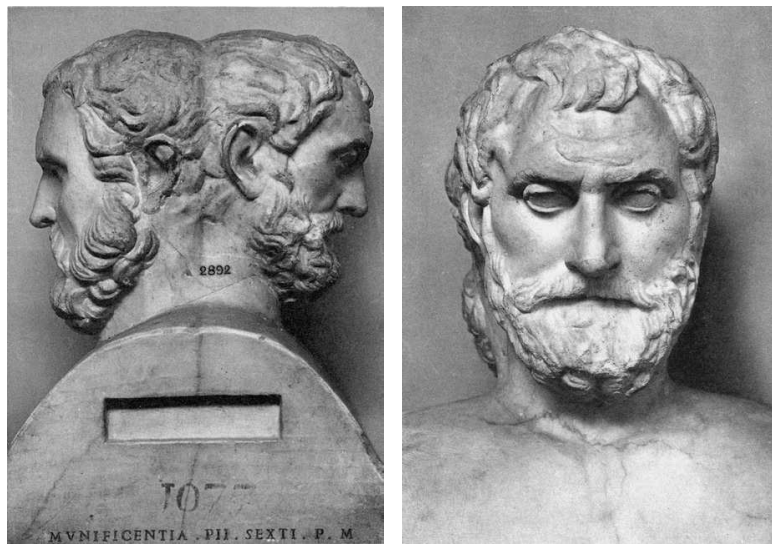

Fig. 23a-b : Unnamed bearded head of Thales(?), arranged with that of Bias of Priene in a double herm. Roman copy of a $4^{\text {th }}$ century BC Greek original. Vatican, Galleria Geografica Inv. 2892 (photo G. Lippold, Die Skulpturen des Vaticanischen Museums III 2, Berlin, 1956, pl. 198, 18 [right]).

The formulation $\alpha \dot{\alpha} \varepsilon \dot{\delta} \delta \iota \xi \varepsilon v . . . \Sigma o \phi i ́ \alpha u$ resembles that of sacrifical regulations: The mothercity sacrificed her sophos metaphorically to Sophia like a bull187. Additionally, Miletos shows off with her cultural leadership in lonia by stressing Thales' achievements as 'first' astronomer: The rare feminine adjective 'Iò ऽ for "Ionian" is first to be found in Herodotus'188, and the very same Herodotus also coined the phrase of Miletos being the "ornament of Ionia" ( $\tau \hat{\text { Y }}$

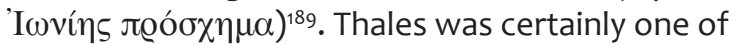
Ionia's crown jewels.

Diogenes Laertius has also passed down the alleged grave inscription of Thales, most probably that of the post-Persian era ${ }^{190}$ :

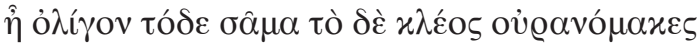

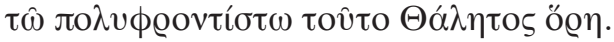

"Here in a narrow tomb great Thales lies, yet his renown for wisdom reached the skies." [English transl. R.D. Hicks]

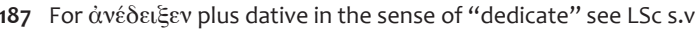

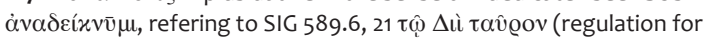
the festival of Zeus Sosipolis, Magnesia on the Maeandrus, 185/4 BC); cf. Sokolowski 1955, 88-92 no. 32, esp. 91 with commentary on I. 21

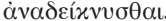

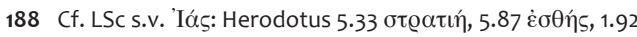
[үuvท́].

189 Herodotus 5.28; compare Pliny, naturalis historia 5.112: caput Ioniae; cf. Herda forthcoming a, § 2.6.

190 Diogenes Laertius1.39 (= Anthologia Palatina 7.84; Diels/Kranz 11 A 1.39).
Is the smallness, skillfully contrasted with Thales' boundless mind, owing to the original grave built by the sage himself? And did this grave survive the destruction of Miletos by the Persians in 494 BC? We do not know as long as we have not found it, an adventure, which seems quite difficult to me, but nethertheless absolutely worth the effort!

\section{Heros Anaximander in the bouleuterion?}

That monuments of the Archaic past of Miletos survived into the Byzantine period, being reused in different functions, is documented by countless sculptures, found reused in Late Roman and Early/ Middle Byzantine contexts ${ }^{191}$.

One of the most remarkable is the lower part of a statue of a long-robed female, broken in two pieces and dated to around 570/60 BC (fig. 24). It was found in the Hellenistic bouleuterion ${ }^{192}$. The dedicatory inscription on the plinthe below the feet identifies it as a dedication of Anaximander ${ }^{193}$. From its first discovery onwards, the statue has been connected to the famous philosopher, pupil of Thales. Anaximander died in the same $58^{\text {th }}$ Olympiad as Thales (c. 547/6 BC), but was C. 14 years younger ${ }^{194}$. At first, the statue was believed to be the depiction of a male and therefore mistaken as a life-size portrait statue of Anaximander. But this cannot be true as it is definitely a female, wearing a foot-long robe (chiton), most probably belted, and covered by a typical East Ionian 'veil-mantle'195.

191 For example: Archaic female seated statues in Miletus: Dally/ Scholl 2009; Bumke 2009; lion in Baths of Faustina: Dally/Scholl 2009, 151 f. figs. 8-9; S.F. Meynersen, in: Bol 2011, 110-113 fig. 45 pl. 52 (VI.23); kouros in the theatre: R. Bol in: Bol 2011, 131-134 fig. 52 (supposedly cult statue of Apollo Termintheus from Myous, which is not convincing to me); seated statues of 'Branchids' and Chares along the sacred road in Didyma: Herda 2006a, 327-350 fig. 18, 20; Dally/ Scholl 2009, 152 f. fig. 10; Archaic kore (Berlin Inv. 1740) dedicated to the nymphs: see below n. 198.

192 The exact find context is lost, see Darsow 1954, 102 with n. 5 (found in the peristyle or the assembly building).

193 C. Fredrich in: Knackfuß 1908, 112 no. 8 fig. 103 (height 0.79 m); Darsow 1954 fig. 1-5; Jeffery 1990, 334, 342, no. 26 pl. 64; Herrmann 1997, 156 f. no. 8; Agelidis 2009, 190 f. with figs.; Dally/Scholl 2009, 146 f. fig. 3.

194 Apollodorus FGrHist 244 F 29 II 1028 (= Diogenes Laertius $2.12=$ Diels/Kranz 12 A 1); cf. Kirk et al. 2001, 109 f. with n. $1 \mathrm{f}$.

195 C. Fredrich in: Knackfuß 1908, 112; followed by Diels 1914, 5; contra: Darsow 1954; Herrmann 1997, 156 f.; Karakasi 2001, 44, 48,167 pl. 36 ("M 1"). On the clothing see Darsow 1954, 106-110; Kriegenherdt 1995. Kriegenherdt 1995 remarks that the left hand was originally raised in front of the trunk, holding a small votive, perhaps a bird. On the motive of the fringe-tip of the veil-mantle 


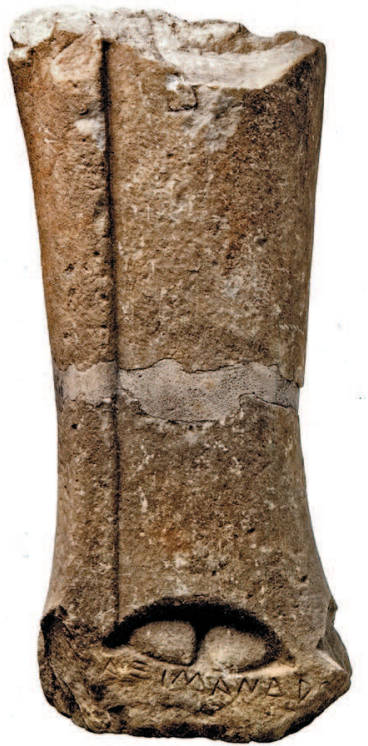

Fig. 24 :

Archaic female

votive statue of one

Anaximander, found in the

Hellenistic bouleuterion,

c. 570/60 BC.

Berlin, Antikensammlung

Staatliche Museen

Berlin Inv. SK 1599

(photo Agelidis 2009, 190)

Fig. 25 :

Relief with seated

Anaximander from Rome,

Via delle Sette Sale,

$2^{\text {nd }}$ century BC. Rome,

Terme Museum Inv. 506

(photo Richter/Smith

1984, 97 fig. 50)

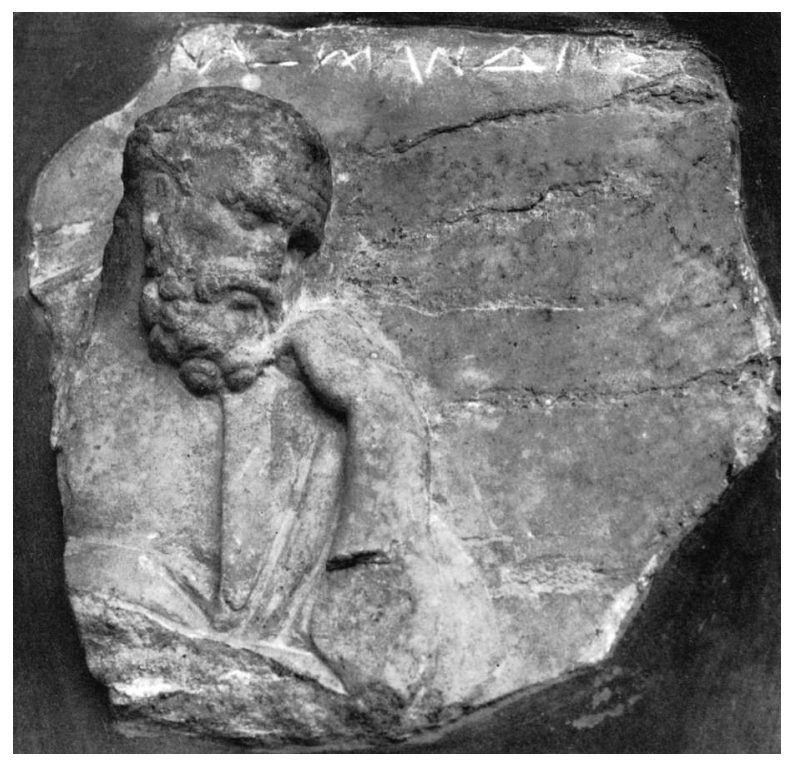

speculate about some kind of cultic veneration of Anaximander in the Hellenistic bouleuterion, which is not attested otherwise. Being the leading philosopher of the Milesian School, he could claim an importance as 'cultural' hero, similar to that of his teacher Thales. Like him he will also have been involved in the re-organisation of the urban planning of his hometown (see $\S$ IV, VII). From the preserved testimonia, Anaximander can be imagined as an utopist and visionary who tried to translate his idea of the cosmic structure into the spatial and political structure of his hometown. Like the earth forming the center of Anaximander's kosmos, surrounded by three fire rings (stars, moon, sun), defined by simple mathematical ratios and definite geometrical proportions, the space of the agora formed the spatial and political center of the polis, whose society was divided in three classes of citizens (aristocrats, middle class, poor), interacting according to the rule of oligarchic isonomia ${ }^{199}$. This may have qualified him sufficiently

this type from Miletos of the same period with the votive inscription of a certain Mandrios to the Nymphs. The statue, now in Berlin (Inv. 1740) was until recently wrongly attributed to Samos: Karakasi 2001, 14 with n. 23, p. 48, 167 pl. 36 ("M 1A"). Instead, it was found in a modern wall within the ancient city of Miletos: Ehrhardt 1993, $3 \mathrm{f}$. 199 Aristotle, de caelo B 13.295b 10 = Diels/Kranz 12 A 26.1-5; cf. Hahn 2001, 182 f. (refering to Th. Gomperz, J.-P. Vernant and G. Naddaf); Naddaf 2003, 31. For the tripartite structure of the Archaic Milesian society see Phocylides of Miletos, a contemporary of Anaximander, fr. 12 (Bergk): "Many things are good for men who are in the just middle. In the city, I want to be a man of the center."; cf. Naddaf 2003, $30 \mathrm{f}$. The "ursprüngliche Endzahl der primitiven Menscheit" 
for being a suitable hero in a bouleuterion. For this we can compare the heroon of Bias, located in the prytaneion of Classical(?) Priene (see § VII).

The date of origin of Anaximander's postulated hero cult is mere speculation: It can already have existed in the later $6^{\text {th }}$ century $B C$, as is the case for the cult of Thales, or that of the Chares, commander of Teichiussa, a Milesian phrourion, whose portrait statue formed the seventh station of the New Year procession to Didyma ${ }^{200}$. One may take these Milesian examples as an indicator for the growing body of official hero cults of recently deceased persons in the second half of the $6^{\text {th }}$ century $B C$, adding new professions (athletes, philosophers, military, poets) to the most spread and earliest attested Greek hero cult of historical persons, that of the founders of colonies.

If we neglect a hero cult of Anaximander in the Hellenistic bouleuterion, the assumed presentation of an Archaic statue with dedicatory inscription of Anaximander at least hints at the possible function of the bouleuterion as a quasi archive for interesting memorabilia of Miletos' great past, a function sometimes also assigned to prytaneia ${ }^{201}$. One may finally hint at the practice of erecting honorary statues in public buildings ${ }^{202}$.

\section{A recent hypothesis on an intramural, subterranean chamber grave: heros ktistes versus temenitai}

In a new book on Ionia, Wolfram Hoepfner has proposed to identify a subterranean chamber west of the Hellenistic Bouleuterion with the grave of a founder of Miletos (figs. 26, 27a-b). He dated it in the Archaic period and located it in the agora ${ }^{203}$. The chamber is only 3.05 by $1.53 \mathrm{~m}$ and $2.09 \mathrm{~m}$ high, it was closed by a plug door. The chamber as well as a tiny antechamber on a slightly higher level had

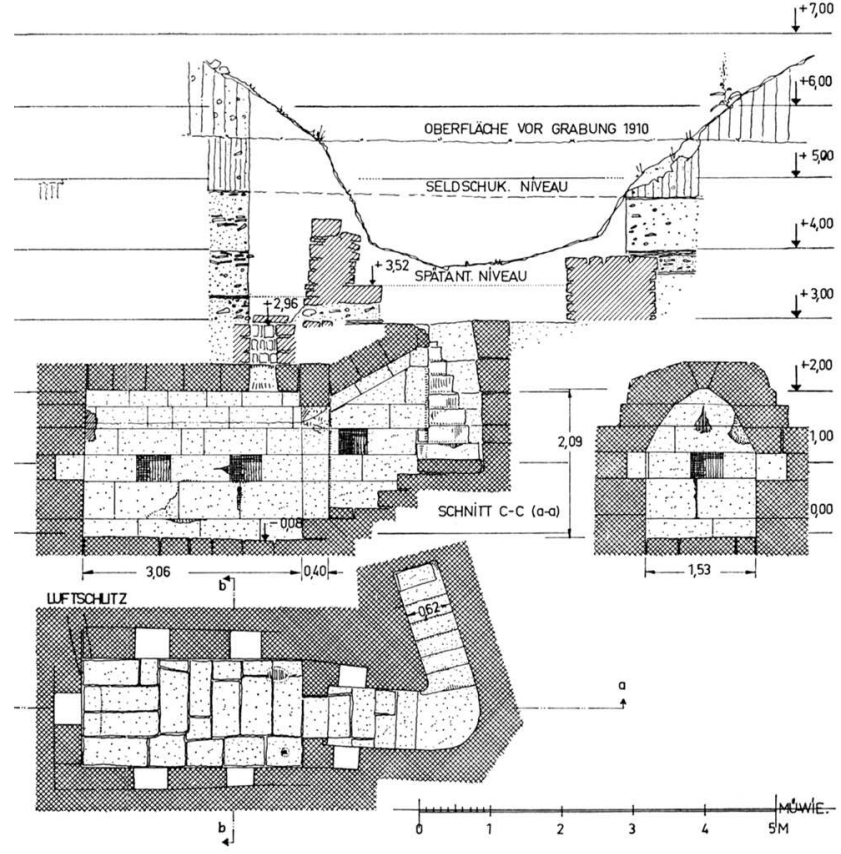

Fig. 26 : Subterranean chamber west of the bouleuterion, Hellenistic(?), groundplan, longitudinal and cross section (sketch W. Müller-Wiener in: Müller-Wiener 1972, Beilage 6).

seven niches in the walls. A staircase of ten steps led to the antechamber ${ }^{204}$. Hoepfner leaves open to which of the Milesian founders the grave may have belonged. He compared the structure with the Late Archaic subterranean grave in the agora of Poseidonia-Paestum in Italy. The latter grave consisted of a built-chamber without any entrance, having a gabled roof, on which an additional roof made of terracotta tiles was later placed, covered by a tumulus. The grave included several hydriai and amphorae made of bronze and terracotta, standing along the walls and filled with a brown sticky substance, the remains of a bed, as well as five iron spits lying on a central stone basis. It has been interpreted not as a grave, but as a cenotaph for the founder of Poseidonia, because bones or ashes of a cremation are missing ${ }^{205}$.

(H. Usener), the number " 3 " (see below n. 238), may also stand behind Anaximander's concept of the apeiron, "the Boundless, Infinite", which is the arche, the "principle' of all being. The " 3 " is also extant in the number of the three continents Europa, Asia and Lybia, as counted by the Ionian philosophers: Herodotus 2.16; cf. Naddaf 2003, $35 \mathrm{f}$.

200 Herda 2006a, 327-350, 440 f. figs. 9, 17-18, 20, 22.

201 Miller 1978, 16 f. (Athens, Solonian law code; Cyzicus, anchor of Argonauts).

202 Miller 178, 17 again for prytaneia.

203 Hoepfner 2011, 74 f. with fig. 35; cf. 72 fig. 34 "Heroon?".

204 G. Kleiner in: Kleiner/Müller-Wiener 1972, 54; W. Müller-Wiener in: Kleiner/Müller-Wiener, 1972, 69-71 Beilage 1, 4, 6, pls. 18, 1-3. Regarding the function as grave $O$. Henry kindly remarks in a letter of March 20, 2012: "As for the structure in Miletos, I would also think that it is a tomb. Mainly because of the door system: a plug door which is really hard to open and close again, especially since it is located on the staircase". Another argument are the niches where urns could be placed. This implies a multiple use of the grave. 205 See above n. 107; an alternative interpretation as Tritopatreion: Rausch 2000; critical on Rausch: Stroszeck 2010, 73 n. 113. 


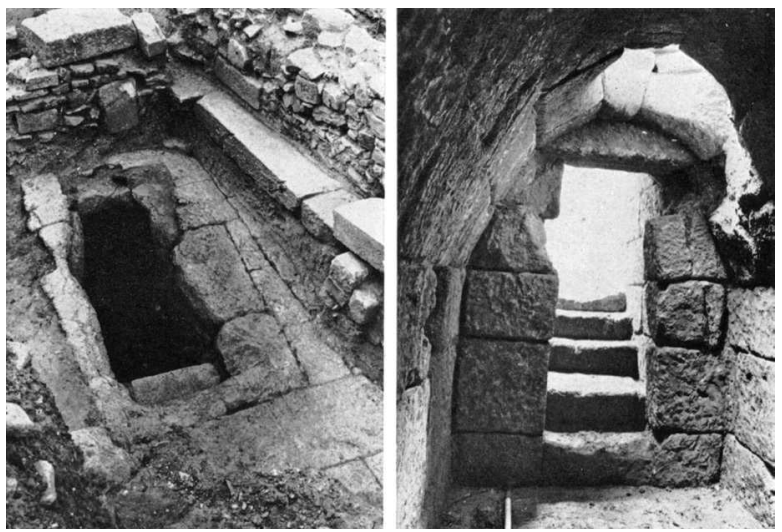

Fig. 27a-b : Subterranean chamber west of the bouleuterion, Hellenistic(?), a. entrance from outside, b. door from inside (photos Müller-Wiener 1972, pl. 18, 2-3).

Hoepfner's proposal seems very attractive at first sight. However, neither is the chamber located in the agora, nor is a dating likely to the Archaic period. To begin with the dating: The pottery finds behind the walls flanking the staircase were predominantly Archaic, but included some later material ${ }^{206}$. Wolfgang Müller-Wiener therefore dated the whole structure to the Hellenistic period, also taking into account the vaulted roof of the antechamber and the 'mixed' construction of a corbel-vaulted roof with a closing keystone in the main chamber ${ }^{207}$. The pavement surrounding the mouth of the staircase seems to have been installed not before the Roman Imperial period, judging by the pottery found under $\mathrm{it}^{208}$. In the last period of use, in Late Roman or early Byzantine times, an opening was cut into the roof of the main chamber, which was now used as a cistern ${ }^{209}$.

206 W. Müller-Wiener in: Kleiner/Müller-Wiener 1972, 70: “(...) in der darunter folgenden Auffüllung hinter den die Treppenwand bildenden Quadern dagegen dominierte archaisches Scherbenmaterial (...)".

207 W. Müller-Wiener in: Kleiner/Müller-Wiener 1972, 70: “Nach der in Milet üblichen Material-Chronologie sowie nach den Mauerwerksformen zögert man freilich mit einer derart frühen [Archaic, A.H.] Ansetzung; die Grottenanlage wäre danach am ehesten in hellenistische Zeit zu setzen". He also hinted at Bronze Age graves with a comparable roof construction in Ras ShamraUgarit, stressing that this has no implication for the dating of the Milesian grave. O. Henry kindly remarks in a letter of March, 20, 2012: "As for the date I would also think of the Hellenistic date for both the vault and the niches".

208 G. Kleiner in: Kleiner/Müller-Wiener 1972, 54 mentions only Archaic to Hellenistic finds under the pavement, but W. MüllerWiener in: Kleiner/Müller-Wiener 1972, 70 n. 27 explicitly refers to the rim fragment of a Roman Imperial Period sigillata bowl. 209 Müller-Wiener in Kleiner/Müller-Wiener 1972, 70 Beilage 6; Tuttahs 2007, 53 f. figs. 38-39. Tuttahs' positioning in 44 fig. 28 "8”, compare p. 53 "an der Südostecke des Bouleuterions" is incorrect.
Regarding the location of the grave: From the early $6^{\text {th }}$ century $B C$ on, the area where the grave is located forms part of the street-insula-grid system (figs. 2, 6; 19) ${ }^{210}$. This place was not an open space, but covered with the building structures of an insula ${ }^{211}$. Nevertheless, the agora was close by, only one insula-block to the East, and the next insula to the Northwest housed the sanctuary of Dionysos, which is at least of Archaic age, marking the importance of this city district ${ }^{212}$.

All in all, Hoepfner's hypothesis of the chamber tomb being the Archaic grave of a Milesian founder hero (heros ktistes) has to be abandoned. Its position close to the city center is remarkable, being under one of the houses of an insula. What is also remarkable is the permanent accessibility of the complex via the staircase, as well as the seven niches, resembling the five additional loculi in 'Heroon I', the supposed grave of Dokimos (see $\S \mathrm{I})^{213}$. This is a clear hint of a multiple burial place used over a longer period, otherwise typical for family graves. But within the city wall, where - in contrast to heroa which were exempted from that rule (see $\S \mathrm{V}$ ) - regular family burials of citizens were unusual due to ritual impurity ${ }^{214}$, another possibility seems more suitable to me: The burial ground of a burial-association, not organized according to family structures. This calls into mind a whole series of so-called temenitai-inscriptions from Hellenistic

210 Herda 2005, 279 fig. 29 (Archaic), 273 fig. 25 (Classical). Most recent map of the grid, though diachronic: Graeve 2006, 258-262, 257 fig. 8; only Archaic: Graeve 2009, 26 fig. 1. The map in: Hoepfner 2011, 72 fig. 34 for the early Classical city is misleading as it does not take into account the Archaic-Classical insulae west and southwest of the later Hellenistic bouleuterion (for an Archaic insula underneath Roman Heroon III see now: Herda/Sauter 2009, 86 f. n. 199 fig. 9). Additionally, the shore line in the city center shows remarkable deviations from the older reconstructions Hoepfner is relying on, see now provisionally: Müllenhoff et al. 2009, $20 \mathrm{Abb} .1$.

211 W. Müller-Wiener in: Kleiner/Müller-Wiener 1972, 71, Beilage 1 ("unterirdischer Gewölberaum”), Beilage 4 ("unterird. Kammer”). 212 Müller-Wiener 1977-78 and 1979 and 1988; Hirsch 2001, 218-228 figs. 1-3; Herda 2005, 272-278 and 2011, 73, 64 fig. 2.

213 The niches are large enough (0.38-0.47 m broad, $0.36-0.38 \mathrm{~m}$ high, 0.25-0.43 $\mathrm{m}$ deep) to house ash-urns.

Beneath Heroon III there is also a small Hellenistic underground chamber ( $2 \times 2 \mathrm{~m})$, accessible via a staircase of eleven steps. But this chamber, which has a large niche $(1.00 \mathrm{~m}$ broad, $0.75 \mathrm{~m}$ high, $0.50 \mathrm{~m}$ deep) in the west and a small lamp-niche at its right side, seems to have been a storage room for wine amphoras as there was found a large amount of Hellenistic amphora sherds inside. Against its function as a grave also speaks the absence of a door: Weber 2004, 140 figs. 79, 86 pl. 43, 1 Beilage 1 ("Kellerraum").

214 Death causes ritual impurity, a pollution (mysos, miasma), which calls for ritual cleaning. Therefore death-related things are regularly excluded from sanctuaries and the city: Parker 1983, 32-73, 338; Burkert 2011a, 125 f., 138, 293. See on related funeral laws: Frisone 2011, 184, 186, 190, 194. 
Miletos ${ }^{215}$. These attest several associations of temenitai or temenizontes, part of them metoikoi, non-citizens from abroad, venerating specific gods in their own sanctuaries (temene), where they, at least partly, also placed their collective burials ${ }^{216}$. Most of the inscriptions were found close to the Değirmen Tepe in the south-western outskirts of the city, where part of the Hellenistic necropolis was located. But two were found within the city, one of them northwest of the Hellenistic bouleuterion, exactly in the area where our chamber tomb is located. It lists at least twelve persons, called temenizontes, and is dedicated to Apollo, Zeus and Aphrodite. The list whose present whereabout is not known, was dated to the $1^{\text {st }}$ century BC out of prosopographical reasons ${ }^{217}$.

Alltogether we may suspect the subterranean chamber tomb to be part of a Hellenistic intramural grave-temenos, with a representative building on top, comparable to the peristyle structure of Heroon III ${ }^{218}$ or the well known (extramural) Heroon of Leon in Kalydon, both including rooms for ritual feasting ${ }^{219}$. Maybe this is also true for Heroon I, as it also contained multiple burials and a dining room, at least in its last phase, dated to the Roman Imperial time (see above $\S \mathrm{I}$ ).
215 These Milesian temenitai-inscription attesting grave-associations beside the common family-structures are overseen in the otherwise excellent article of Harter-Uibopuu/Wiedergut forthcoming. 216 Herrmann 1998, 93-97 nos. 795-804; cf. Herda 2006a, 197 n. 1382 , p. 313,348 f. with nn. 2496-2498, 2501. For a temenos seperate from the burial ground see next note on nos. 797 and 798 . 217 Herrrmann 1998, 94 no. 797. According to Herrmann, the grammateus Andronikos, son of Myonides, mentioned in line 4, may be identical with a person of that name and patronymicon in Herrmann 1998, 95 no. 798, line 12. This temenitai-inscription, dated to the 40 -ies of the $1^{\text {st }}$ century $B C$, was instead found within a grave complex on Değirmen Tepe. If no. 797 also originates from there and was later brought to the area west of the bouleuterion, remains open. If this is not the case we have to assume that the association's temenos for Apollo, Zeus and Aphrodite was located within the city, while their burial ground was in the Değirmen Tepe necropolis. The other temenitai-inscription from the city is Herrmann 1998, 96 no. 801 , found 1905 "in den römischen Thermen im Bereich des Eumenes-Gymnasiums westlich vom Stadion”. Not clearly belonging to the corpus is a list with female names which was attributed to a Dionysian thiasos: Herrmann 1998, $98 \mathrm{f}$. no. 809. It was found in the large Hellenistic magazine west of the South Market, which is not far from no. 797. A fourth name list was found west of the bouleuterion: C. Fredrich in: Knackfuß 1908, 117 f. no. 13; Herrmann 1997, 158 f. no. 13 (early $2^{\text {nd }}$ century $B C$ ).

218 I have suspected Heroon III to be the temenos of a cult association, probably of Apollo Didymeus and the goddesses of Good Hope: Herda/Sauter 2009, 94 n. 252.

219 On Kalydon see: Dyggve et al.1934; Kader 1995, 205-209, 221, 227 fig. 3.4-5.

\section{Some final remarks on Greek hero cults}

Considering the evidence of countless mythical or mythistorical hero-cults in the growing city-states of mainland Greece, it seems illogical to assume that the "heroization of founders [in the Archaic colonies, A.H.] provides the earliest and clearest instances of hero cult in the Greek world"220. Instead, the cult of specific, personalized heroes of exceptional moral qualities ${ }^{221}$ as distinct part of the cult of the dead was always present in Greek culture as an Indo-European heritage from at least Bronze Age on ${ }^{222}$, forming a difference to e.g. the Ancient Egyptian culture, which does not know half divine, half human heroes, but clearly separates gods from men without any intermingling - except the pharaoh -, so that gods "do not run into" humans ${ }^{223}$.

220 Antonaccio 1995, 268; see also Antonaccio 1999 and 2011, 351. Bremmer 2006, $19 \mathrm{f}$. lowers the beginning of hero cults in Greece even more, to the late $6^{\text {th }}$ century $B C$ ! Before, there had only been "tomb cults, cults of ancestors, and cults of founders of cities". It remains open why he does not count founders for heroes. 221 The assumption of Habicht 1970, 269 that the divinized rulers received their honours only because of their political power, not because of their moral perfection ("sittliche Vollkommenheit"), is only functional and dismisses the immanent metaphysical and moral function of ancient (as well as modern) religion. The same is true for the comment of Himmelmann 2009, 21 that the "Heros ist ursprünglich ein Wesen jenseits von Gut und Böse. Er wird nicht verehrt, weil er im Leben ein Tugendheld war, sondern weil er ein mächtiger Totengeist, ein gegenwärtiges Numen ist”. See now Anderson 2009 on heroes as moral agents and examples. 222 Farnell 1921, 358: "One has then the right to regard some form of ancestor-cult as of indefinite antiquity in Greece. We may believe on the analogy of other societies that it developed with the development of settled agricultural institutions, with the rights of property in land, the ancestral grave belonging to the family plot". Mycenaean elite graves and funeral iconography show all elements typical for later 'hero-cult': animal sacrifices, libations, feasting, athletic contests, postfuneral rituals: Gallou 2005. That the Romans took over certain heroes from the Greeks while not distinguishing them from the gods (dei), as Graf 1998, 478 supposes, demands further research, but does not seem convincing to me. The myth that Roman culture lacked myths is a warning example. Also is ancestor cult, closely related to the hero cult, typical for the ancient Indian as well as Roman culture, suggesting Indo-European heritage: Hemberg 1954, 180. For ancestor cults in the Hittite and Near Eastern dynasties see Haas 1994, 239-248. For the Etruscan and Roman ancestor cults see Steingräber 2002 and below note 263.

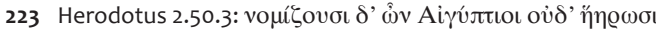
oủঠćv ("The Egyptians, however, are not accustomed to pay any honours to heroes.", transl. A.D. Godley); cf. Parker 2011, 117; Assmann 2009, 12 misses any sign of herioc myths in Egypt: "In Egypt the gods do not run into you, and girls and boys can be as beautiful as they are, without being disturbed ever" (“In Ägypten laufen einem die Götter nicht über den Weg und man kann als Mädchen oder Jüngling noch so schön sein, ohne je belästigt zu werden”). However does Robert Hahn remind me of the fact that the pharaoh 
The distinction between Greek hero cult and the cult of the dead ancestors seems likewise artificially overemphazised to $\mathrm{me}^{224}$. Both are the outcome of the same inherited religious phænomenon in Indo-European cultures, "an Indo-European eschatology"225: the believe of an afterlife of the soul ( $\left.\psi \cup \times n^{\prime}\right)$ that can still intervene in favour of the living, when called in via sacrificial ritual ${ }^{226}$. This is also why burning the dead corpse of Achilles and other heroes, or of 'regular' dead like Philipp II of Macedon, could not affect the potential power of their soul227. Otherwise, the apotheosis of the Roman emperors would have made no sense: the divus, whose corpse had been burned on the rogus or pyra, the funerary pyre, was thought of as being a superhuman, indestructible, divine power, who had been liftet "up to the gods" in Olymp. Being a heroized ancestor, he could subsequently protect the imperial family as well as the Roman state - at least as long as he was asked for via executing his cult ${ }^{228}$. One is strikingly remembered of the central separation ritual of Hittite imperial funerals: the immortal soul of the deceased emperor or empress, gift of the Sun-god, is liberated and cleaned by burning the mortal body on the pyre, because "to the gods belongs the soul" 229. The 'dying' of the

had to be 'fathered' by Amun Re to be legitimated. The title 'son of Re' is common since the fourth dynasty: Bickel 2009.

224 So for example Antonaccio 1995; Böhringer 2001, 37-46; Ekroth 2002, 335-341; Antonaccio 2006, 389-394; Söldner 2009; critical: Deoudi 1999, 40: "Wichtig ist dabei, daß einem mythischen Heros die gleichen Ehrungen zuteil wurden, wie einem unbekannten Heros an einem bronzezeitlichen oder geometrischen Grab, so daß zwischen Heroen- und Grabkult nicht unterschieden werden kann". See already Farnell 1921, 343, who warned: "The cult of heroes and the cult of ancestors frequently overlap, and the forms of ritual are mainly the same. But it is right to distinguish them, for there is a difference in the root-idea that affects their geographical distribution and the sentiment attaching to them".

225 Watkins 1995, 290.

226 On heroes as 'small-scale gods', local gods, helpful powers: Parker 2011, 103-123. During the Hittite funerary ritual for the dead king or queen is their soul entertained and asked for protecting the dynasty: Otten 1958, 16, 136. When relocating his capital, king Muwatalli II took with him not only the gods, but also the souls of his dead ancestors: see below n. 263.

227 Burkert 2011, $292 \mathrm{f}$. against Rohde's argumentation (Rohde 1925, I 27-32), the burning of the corpse, a funeral ritual introduced only in late Mycenaean times in Greece, would serve the destruction of the corpse to break the power of the dead over the living and ban their souls. It is rightly argued by Burkert and others (Burkert 2011, 292 with n. 7) that only a certain part of burials included the burning of the corpse. On the function of the burning as separation ritual of the mortal body from the immortal, divine soul in the Hittite and Roman imperial funerals see below.

228 Hiller von Gaertringen 1896; Gradel 2002, 261-371; Zanker 2004 229 KUB 43.60, 31-32; cf. KBo 22.178 + KUB 43.109; Watkins 1995, 277-291. The soul (Hittite $\mathrm{Zl}$-anza) is given to men by the Sun-god, see king or queen is therefore called simply "become a god" (DINGIR ${ }^{L M}$-iš kišari), and during the ritual the dead king is addressed "o god" and asked for protecting his children and grandchildren, while in texts of the New Kingdom (1400-1200 BC), written in Anatolian hieroglyphs, the dead? king is always designated with the logogram for the title HEROS, still in 'archaizing' use in the Luwian, 'Neo-Hittite' kingdoms of the $8^{\text {th }}$ century $\mathrm{BC}^{230}$.

As the groups practicing a cult can differ widely, so also can be the rituals of a hero cult ${ }^{231}$. In this regard, the interpretation of archaeological finds

the $8^{\text {th }}$ century BC funerary inscription of 'Late Hittite' king Ruwa of Tabala in Hieroglyphic Luwian: Hawkins 2000, 445 f. no. X.10 Kululu 4 §§1-9, esp. 446 with commentary on § 4; cf. Hutter 2003, 261. On parallels between the Hittite "Great voyage of the soul" and the Orphic voyage of the soul: Bernabé/Jiménez San Cristóbal 2008, 209-217, cf. esp. 211, 214 on the necessary destruction of the mortal body of the "Desired One" (the first borne man). Already Rhode 1925 , I $30 \mathrm{f}$. stressed the cremation as means of dissolving the immortal soul from the dead body (see n. 227). Another aspect of the cremation will have been the purification of the soul by 'going through a cleaning fire' (contra Rohde 1925, I 31, who believed that the cathartic power of fire had no importance in Homeric Greece but only later. But see instead Rhode 1925, I 320-322, where he deals with the "Vernichtung und Läuterung im heiligen Blitzfeuer" of godfather Zeus, he holds for a very old heritage in Greek religion). One may compare the apotheosis of Herakles, whose cremation pyre is hit by Zeus lightning (Diodorus 4.38), or Asklepios, who is killed by Zeus' 'cleaning' lightning, and the ancient saying that somebody who was struck by lightning is going to join the gods and heroes. Additionally, the term for the paradise, where the greatest heroes live, the

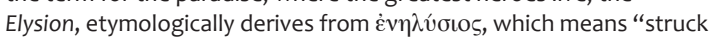
by lightning”: Burkert 1961; Graf/Iles-Johnston 2007, 125 f., 206 n. 54. On "purifying fire" (Euripides, Helena 869 etc.) see Rhode 1925, I 320; Parker 1987, 227; Burkert 2011, 122 f. with n. 6. This is, by the way, why Empedocles jumped into the fire of Mount Etna, to become an immortal hero: Diogenes Laertius 8.75; cf. Kingsley 1995, 252-256. Also related is the phænomenon of ancestor and hero cults at the flame of the sacred hearth in the prytaneion as well as in the private houses; see above $\S$ III with n. 82 .

230 Watkins 1995, 288 n. 18; cf. Otten 1958, 12 f., 17; Haas 1994, 216-229. The 'average' Hittite could be cremated or inhumated, the cemeteries show both customs at least from Middle Bronze Age on (early II ${ }^{\text {nd }}$ millenium BC): Seeher 1993; Haas 1994, 233-237. The logogram for "heros" (Laroche 1960, no. 21) is used to designate the emperor in the Südburg - (Boğazköy 21), Yalburt-, Kızıldağand Burunkaya-inscriptions: Hawkins 1995, 128. It is still in use as archaizing title of late rulers, e.g. in Karkemish (Hawkins 2000, 160 no. II. 32 Karkamiš A21 § 1, c. 738-717 BC) and Bulgarmaden (Hawkins 2000, 523 no. X.45 § 1, C. 738-710 BC). However, Rostislav Oreshko remarks (letter of July 25,2012 ) that according to his understanding the title HEROS can also designate the living emperor. The phonetic value of the logogram and its etymology is still discussed, see the forthcoming PhD of R. Oreshko ("Studies in Hieroglyphic Luwian: Towards a Philological and Historical Reinterpretation of the SÜDBURG inscription", chapter. 3 ).

231 It makes sense to distinguish in the quality (olympic versus heroic/chthonic sacrifice; specific animals, cakes, plants, etc.; dining activities; dedication of figurines, weapons etc.) and quantity (small, large, single/temporal, periodically/long-term) of the rituals as well as the character of the location (reused older grave, grave, cenotaph, etc.) and the practicing groups (family, genos, phratry, polis etc.). 
turns out to be very complicated: The phænomenon of Mycenaean tombs being reused for cult purposes in the $8^{\text {th }}$ century $\mathrm{BC}$ does not mark the beginning of Greek hero cult as often believed, but instead signals a huge increase in its popularity out of different reasons, the most important being selfidentification of social groups, their cohesion, the legitimation of their claim to power and territory ${ }^{232}$. On the other hand, a clear distinction between tomb- and hero cult at a certain burial site is sometimes impossible ${ }^{233}$.

It is the common Indo-European tradition that led Homer borrowing in Iliad 16.456 and 674 the

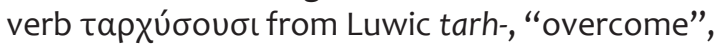
"vanquish", "revivify", the word-stem also behind the Luwian weathergod's name Tarhunt, to designate the ritual of preparing the dead body of Lycian hero Sarpedon for a mystical "revivification" after death ${ }^{234}$. It is also important to stress the high age and important role of heroic figures like Herakles, the prototypic hero per se, whose twofolded, heroic and Olympic cult is Pan-Greek ${ }^{235}$. He is closely connected to the goddess Hera, as his name means "he who has the glory ( $x \lambda \varepsilon \dot{0}$ ) ) of Hera". The goddesses (as well as Herakles') name itself is

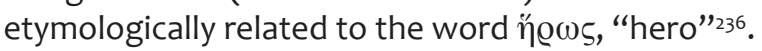

232 Coldstream 1976; Snodgrass 1980, 37-40; Polignac 1995, 138-143; Parker 2011, 287 f. 290.

233 See Parker's critical note (2011, 290): “Hero cult existed before the eighth century (...), but at this point assumed a new and for the first time archaeologically visible form, attaching itself to tombs. The difficulty here is obviously that of explaining the new form. But the uneven archaeological visibility of hero cult, typically conducted on a fairly small scale, is a complication that must always be taken very seriously."

The long discussion, if the warrior of the famous Middle Protogeometric (c. $950 \mathrm{BC}$ ) burial in Lefkandi-Toumba is a hero or not (no hero but a 'normal' dead: e.g. Antonaccio 1995, 241; Sourvinou-Inwood 1995, 94, 116; Seiffert 2005 [not mentioned at all]; Antonaccio 2006; hero: e.g. Deoudi 1999, 62; undecided: Mazarakis Ainian 2004, 136-138 no. 12; Bravo 2009, 18 f.), is fruitless: every dead is a potential hero. Therefore is the question, whether the house on top of the burial was formerly the dwelling place of the deceased or was only built later as a heroon in the context of the funeral rituals, of relatively minor relevance. Nevertheless this matter is hotly discussed: Mazarakis-Ainian/Leventi 2009, 217.

For a critical approach to the archaeological evidence of hero cults in Classical and Hellenistic Greece see now Mangoldt forthcoming. 234 Nagy 2010, 337.

235 On the double character of Herakles, being hero and god: Herodotus 2.44; Pindar, Nemean 3.22; Kron 1971, 145; Parker 2005 , 37 f.; Burkert 2011, 319-324; on the problematic distinction between 'Chthonic' and 'Olympic', which should be replaced by the distinction 'Olympic' / 'Heroic' see: Schlesier 1997, 1189; Ekroth 2002, 310-325 and 2009, 136 f.; Parker 2005; Henrichs 2005 (with reservations); Burkert 2011, 305-310.

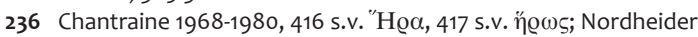

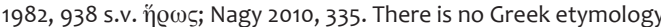

The heroes, whether Panhellenic or local, form a welcome addition to the pantheon of the divinities and are 'interwoven' with them, maybe from the beginning of Indo-European thought and believe, refering to the idea of an initial 'Golden Age', when gods and men had lived together in unity.

The concept of the collective, anonymous family ancestors, the Tritopatores, may also be a Bronze Age tradition, and again an Indo-European heritage ${ }^{237}$. One argument is the appearance of a ti-ri-se-ro-e, Trisheros, "Tripple Heros", in two Linear B-texts from Pylos, where he receives one time rose-scented oil and another time a gold vesse ${ }^{238}$.

so far for urgriechisch *sēr-, 'gewaltsames Nehmen, Raub' ("taking by force, rape"). For an alternative etymology of Herakles name, stemming from the Semitic god Nergal/ Akkadian Erragal, wherefore Herakles is qualified as non-Greek in character and origin: Kingsley 1995, $275,394$.

237 Indo-European heritage: Hemberg 1954, 180 f., comparing the tripartite sacrifice to father, grand father and grand-grand father in Indian funeral rites as well as the Roman arch-ancestor Tritauos in Plautus, Persa 57. Kretschmer 1920, 43-45 thought that Latin Tritauos resp. Tritavus was copied from Greek Tritopator, long before Plautus: "ziemlich alte, d.h. vor-plautinische Wortschöpfung". Why not imagine a commun heritage, instead?

238 Pylos Fr 1204, 172 and Tn 316. Identified with the Tritopatores: Hemberg 1954; Ventris/Chadwick 1973, 289, 586; Chantraine 1968-

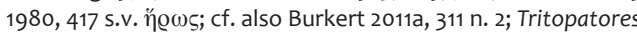
developed out of Trisheros: Antonaccio 1995, 245 with n. 1; Antonaccio 2006, 384 f., 387 n. 9, 393; Antonaccio 2011, 351. On the contrary does Peters 2002, 358-361 neglect the connection of Trisheros in Py Tn 316 with the Tritopatores. He understands Trisheros as 'Dreifachkrieger' (“Tripple-warrior”) and identifies him with Triptolemos who is according to him a 'hypostasis' of Poseidon. Already fifty years before the encipherment of Linear B, Furtwängler 1905, 455 considered the Tritopatores as Mycenaean in origin: "Man möchte indes die Frage aufwerfen, ob nicht in dem ersten

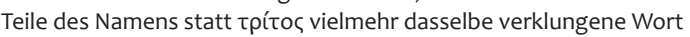
alter 'mykenischer' Epoche stecken könnte wie in dem Namen

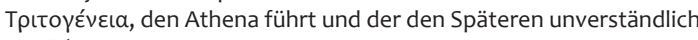
war" (actually do Trito-patores and Trito-geneia have the same first component Tpıтo-, "three": Wüst 1939, 324 f.; Chantraine

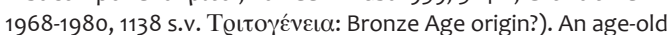
hexametric prayer for the sake of a legitimate, 'true' son ( $\pi \alpha i$ s

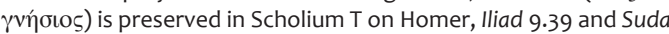

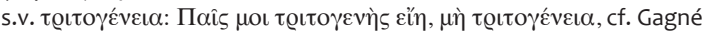
2007, 3 with n. 11. If it is indeed addressed to the Tritopatores, the 'legitimate ancestors', the contrary connection between them and the term tritogenes/eia in the sense of 'legitimately born', becomes evident: cf. Lippold 1911; Kretschmer 1920; Chantraine op. cit. Usener $1903,357-360$ and Hahn 2003, $88 \mathrm{f}$. both suggest, in analogy to ethnological comparisons, that in Greek culture the number " 3 " was "absoluter Ausdruck der Vielheit" and could symbolize "the highest number and was the equivalent to 'a lot'", stemming from a time, when no one could count above three (the three joints of a finger). H. Diels first called the " 3 " in 1897 "die ursprüngliche Endzahl der primitiven Menscheit" (cf. Usener 1903, 362). Compare e.g. the still valid German saying: “Der kann nicht mal bis “Drei' zählen”. In this sense the Tritopatores or Tripatores would have been the 'very first ancestors' with the highest thinkable number of generations leading back. See also Farnell 1921, 355: "early expression of an indefinite remoteness of ancestral affinity". 
The other indication is the wide distribution of the Tritopatores, who are not restricted to Attika, but appear also in Boeotia, in Phokis(?), as well as they spread over the central and western Aegean, implicating their early genesis ${ }^{239}$. If we count the age-old Apatouria, the festival of a-patro-horia, "ensuring the common father" ${ }^{240}$, for one of the festivals where the Tritopatores received cult ${ }^{241}$, we may also include the Greek East as their home, implicating a cult-transfer with the migrating Greeks in Protogeometric times or even earlier ${ }^{242}$. Important to note is also that the Tritopateres as collective ancestors of the polis-states of Selinous and Kyrene have, like Panhellenic Herakles, a heroic, 'impure' as well as a divine, 'pure' aspect, stressed by the two kinds of sacrifices, 'heroic' and 'olympic', the latter at least offered to them in the city's political heart, the agora ${ }^{243}$. It may well be that Solon, in the context of his new funerary laws aiming at reducing the excessive public display of the aristocratic families during burials-

239 Jameson et al. 1993, 111. Tritopat(r)ees of Arneion (= the genos of the Arneiadai?) in Thebes c. 400 BC: Kalliontzis/Papazarkadas 2013; Tritopatores of the Boiotoi in Archaic Delphi(?): SEG LVII 488; cf. Kalliontzis/Papazarkadas 2013, 170 with n. 33.

240 Lippold 1911, 105 f.; Burkert 2011, 384 n. 108.

241 See Harrison 1912, 498-500, though she doubted the high age of the patrilinear Apatouria because of her theory of a former matrilinear society (cf. Harrison 1908, 261, 273; Harrison 1912, 386). Referring to the etymology of Tritopatores and Apatouria, as well as to the fact that the concept of the Tritopatores also encounters in the Vedic Sapinda-fathers (see Rohde 1925, I 247 f. n. 4), speaking for their Indo-European root, we have to assume the patrilinear concept as Indo-European.

242 On the Apatouria in Ionia: Herodotus 1.147; cf. Burkert 2011, 346; Herda forthcoming a, § 2.5.4, 2.5.6. Miletos is one of the few places in Asia Minor where Greeks were settling since the Late Bronze Age (settlement phases Miletos V-VII). This implicates the transfer of Greek cults into the region, where they could merge with indigenous believes: see e.g. Herda 2009; Herda/Sauter 2009; Herda forthcoming b. That the Tritopatores do not appear in Asia Minor so far seems a pure matter of accident to me. On Delos, an altar was dedicated to the Tritopator of the Attic genos of the Pyrrhakidai before 403 BC: IDélos I 66; cf. Gagné 2007, 2 with nn. 5, 7; Papazarkadas 2011, $294 \mathrm{f}$

243 See above $\S$ V with $n$. 111. It remains possible still, that both cults of the impure and pure Tritopatores took place not at different places (so Curti/van Bremen 1999, whose argument I am following here), but at the same spot: Jameson et al. 1993; Vonderstein 2006, 212; Rausch 2000, $111 \mathrm{f}$. If this was in the agora of Selinous, it would imply the (at least temporal) presence of the impure Tritopatores in the city center. This is only imaginable when the sanctuary was a clearly marked abaton or adyton, an area "not to be entered", like the one in the Athenian Kerameikos: Stroszeck 2010, 58-60, or the 'crossroads shrine' (= Leokoreion?) in the agora, which is surrounded by a parapet lacking an entrance: Kron 1999, 80 fig. 10. By this it could be avoided to spread the miasma, hold back within the limits of the heroon (or in the opposite case: to avoid violating the purity within a sanctuary by bringing in something impure: Parker 1983, 167) ceremonies, transformed the traditional festival of the genesia, dedicated to the cult of the ancestors at the tombs of each Athenian family on a distinct date, into a yearly public festival ${ }^{244}$. It makes good sense that these Solonian public genesia also adressed the public Tritopatores as newly created communal ancestors of all Athenians at the state Tritopatreion ${ }^{245}$. Comparable to the individual ancestors of each family, these public Tritopatores not only served for strengthening the identity and cohesion of the Athenian people and proofed their autochthonous offspring, but also acted as their protectors and guarantors of future procreation ${ }^{246}$.

In the time of Homer, the cult of individual heroes has already a long tradition and is fully developed, best to be seen in the outcomes of the genre of epic poetry ${ }^{247}$, and the fact that in Homeric epic the word heros has a religious meaning 248 . lliad and Odyssey picture the heroes, male or - less often - female ${ }^{249}$, as stemming from the gods,

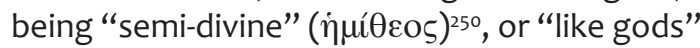

244 For the public genesia, conducted on the fifth day of month Boedromion, see Jacoby 1944; Parker 1996, 48 f.; Iles-Johnston 1999, 43-46; Frisone 2011, 191 f. n. 67.

245 Compare the sacrifices on the birthday of heros ktistes Aratos in the agora of Sikyon: Plutarch, Aratus 53; see above n. 106.

246 Harding 2008, $17 \mathrm{f}$. Parker 2011, 291 tends to deny ancestor cult in Greek culture at all, though he remarks: "the closest Greek equivalents to ancestors, the Tritopatores, were not normally worshipped at tombs though they might be worshipped near them". In the case of the family Tritopatreion in the Athenian Kerameikos, the tight connection to a burial site is evident, the same is true for the state Tritopatreion close by the grave of Battos in the agora of Kyrene; cf. Hemberg 1954, 176; see § V.

247 Nagy 1999; Watkins 1995, 483-487 esp. 486: “(...) but the underlying system which formulaically conveys the definition of HERO is a linguistic and socio-cultural inheritance from common Indo-European times"; etc. See also Meier-Brügger 2006, 424: "It cannot be denied that long before $700 \mathrm{BC}$ singers already sang about heroes. It is also indisputable that individual elements of the epic dialect are old and may certainly be of Mycenaean or pre-Mycenaean origin".

248 Parker 2011, 288 n. 3 contra Bremmer 2006, 17 f. and others (see below n. 254). See also Nagy $2011 a$.

249 On heroines see Larson 1995; Lyons 1997; Parker 2011, 106. Bremmer 2006, 17 remarks: “(...) but these [the heroines, A.H.] are, I regret to say, clearly less important". On the remarkable Leokorai, heroines of the Athenian phyle Leontis, serving as "role-models of patriotic behaviour for the men of the tribe": Kron 1999, 81. On the daughters of king Kekrops, Aglauros, Pandrosos and Herse, occupying a prominent place in Athenian religion: ibid. $81 \mathrm{f}$. Farnell 1921, 358 explained the lower number of heroines ("scarcely a higher ratio than one to six") with the connection of hero cult to ancestor cult and land ownership, claimed by the patrilinear Greek households.

250 Cf. Homer, lliad 12.23. I cannot follow the argument of West 1978, 191 and Bremmer 2006, 24 f. that $\eta \mu$ í $\theta$ cos means not "semidivine" but "almost divine" without designating the half-divine offspring of the heroes. See also Bravo 2009, 14 f. with nn. 27, 30; Parker 2011, 288 f.; Nagy 2011a, 349 f.; and Currie 2005, 64 n. 38: 
(ioó $\theta \varepsilon 05)^{251}$. Still alive, they already receive "godlike honours", as for example Aeneas, son of Aphrodite, from the Trojan people ${ }^{252}$. Famous is Hesiod's saying about the fourth generation of mortal humans, the heroes, created by godfather Zeus and direct ancestors of the fifth, "Iron" generation, the poets own, he "wished he were not counted for but died

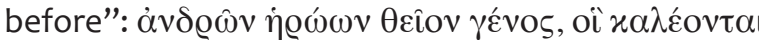
$\eta \mu i \operatorname{\theta \varepsilon ol}$, "they were the divine race of heroes, who are called demigods" 253 . These heroes figure as a moral exemplum for the elite of the Iron race, being their semi-divine forefathers and as such adressees of cultic veneration ${ }^{254}$. The best of them

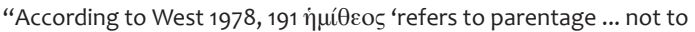

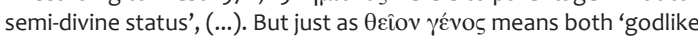
race' and 'progeny of the gods', so too i $\mu$ í $\theta \varepsilon \mathrm{s}$ surely means both 'demigod' as well as 'having a divine parent'. Not only is a ijuíoıvos, 'mule' (West's example), born of an ass, it is also a hybrid: half horse and half ass. Heroes likewise are hybrids, composites of man and $\operatorname{god}(. .) .$.

251 Cf. Homer, lliad 2.565; Odyssey 1.324.

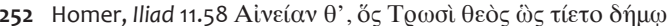
253 Hesiod, Erga $159 \mathrm{f}$. I doubt, that the fourth generation of the heroes is an invention of Hesiod, he himself added to the four metal generations (gold, silver, bronze, iron), and that this four-generation sequence can be traced back only to a $9^{\text {th }} / 8^{\text {th }}$ century BC Aramaic oracular, 'Sibylline' text: so Burkert 2011b, 213-220. This assumption rests mainly on the hypothesis (see also next note) that the cult of heroes was invented in Greece only in the $8^{\text {th }}$ century BC under the influence of the epics: Burkert 2011a, $312 \mathrm{f}$. and 2011b, 167; see the critics on this and other theories about the origin of hero cults: Parker 1996, 33-39 and 2011, 287-292. Regarding the metal agessequence does Burkert 2011b, 75, 215 n. 38 himself hint at a Bronze Age Hittite ritual text (ANET 356), listing silver, gold, iron, bronze (in this sequence) and some precious stones. This leaves open the opportunity of an IE tradition in the Hesiodic text. At least the Vedic tradition knows of a cycle of four ages corresponding the four seasons, called Yuga, and named by declining qualities, depicted as the colors of Vishnu (Krita/Satya Yuga = white = first, perfect age; red; yellow; black), in Iranian Zoroastrism do four up to seven metal branches of the cosmic tree stand for subsequent declining ages (gold, silver, bronze, copper, tin, steel, "mixed” iron): Sauzeau/ Sauzeau 2002, 288-293. To me it seems most logical to assume that the new in Hesiod is not the invention of the age of the heroes, but its arrangement, as fourth age, within the four metal ages. The clear distinction between the age of heroes and that of the "mortals as they are now" (oîlou vv̂v ßootoí cioıv), is always present in the Homeric epics (cf. Homer, lliad 5.304; 12.383, 449; 20.287), as they narrate the end of the Heroic Age: Haubold 2005, 26, $27 \mathrm{f}$.

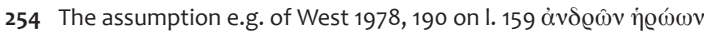
that in Hesiod "as in Homer the term

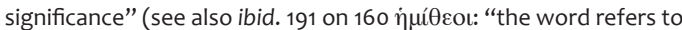
their parentage (...), not their semi-divine status”; and pp. 366-375 Excursus I. Some Names and Epithets of Gods), was influential (see e.g. Boehringer 2001, 25; Peters 2002, 357 f.; Currie 2005, 60; Bremmer 2006, 17 f.; Seiffert 2009, 352) but misleading, as West does not neglect the existence of hero cults per se before Homer and Hesiod: West 1978, 370-373; cf. Bravo 2009, 16, 18. SourvinouInwood 1995, 52 likewise found it "extremely unlikely that the dualism common dead/Hades v. select few/paradise had existed in Mycenaean times" and assumed "the emergence and development of hero cults from the eighth century onwards". Cf. Mazarakis Ainian stay on the Isles of the Blest ${ }^{255}$, or in the Eleusian Fields ${ }^{256}$, living on forever, sometimes visited by the gods and dining with them. Erechtheus the Athenian even shares his cult place with the local goddess Athena on the Acropolis 257 .

The heroes form a bridge between humankind and the divine, being always able to intervene for the fortune or misfortune of men and a permanent promise for a happy afterlife ${ }^{258}$. Robert Parker rightly stresses the "mixed character of the heroes, mortals by biography, small gods in power" 259 .

It is nearly impossible for a human to become a god. Exceptions are rare and first restricted to mythical heroes like Herakles, Achilles and Asklepios ${ }^{260}$. But in 414 BC, a certain Peithetairos manages, with the help of philanthropist Prometheus, to take over power from Zeus after building “Cloudcuckooville", the new 'Olymp' of the birds, which is cutting off the gods from their sacrifices resp. 'feeding' by the humans on earth. This is decribed with much humour by Aristophanes in his comedy Birds by refering to an ancient IndoEuropean myth, also present in the Hittite Kumarbi myth ${ }^{261}$. The triumphal advent of Peithetairos in Cloudcuckooville forms a model for the later deification of the Roman emperors via the process

2004, 131-133 who also dates the emergence of hero cults to the $8^{\text {th }}$ century BC, "based on the archaeological record" and the historical model of "constant strife for power between social classes". On the ethical aspect of (Indo-European) hero cults see above n. 221. 255 Hesiod, Erga 170-173. The 'Islands of the Blest' where located in the extreme Northeast and Northwest of the Greek oikumene: Leuke in the Pontus was dedicated to heros Achilles, Palagruža in the Adria to Diomedes: Parker 2011, 244-246. Both cults may have been invented in the course of the Greek colonization from the $8^{\text {th }} / 7^{\text {th }}$ century BC on: Farnell 1921, 286 (Achilles), 290 (Diomedes). 256 Homer, Odyssey 4.561-569. On the etymology of Elysion as 'struck by lighting' see above n. 229.

257 Homer, Iliad 2.546-551; Odyssey 7.80-81; cf. Coldstream 1976, 16; Kron 1976, 33 (no later emendation of the Iliad-text); cf. Parker 1996, $19 \mathrm{f}$.

258 Opposite understanding by Morris 1987, 201: “The hero was a liminal figure, characterised by the epithet 'god-like' and yet at every turn helping to create the boundary between men and the gods." 259 Parker 2011, 292.

260 See for the apotheosis of Herakles: Hesiod, Fr. 25, 20-33 (Merkelbach/West); cf. Calame 2005; Burkert 2011, 321. For Achilles see Burgess 2009; Herda forthcoming a, § 2.3.2. On the double character of Asklepios see Riethmüller 2005, 51-54; on the apotheosis of Asklepios: Riethmüller 2005, $48 \mathrm{f}$. On the divine side is only Dionysos called a heros by the women of Elis: Plutarch, Questiones graecae 299AB; cf. Brelich 1958, 362-372; Burkert 2011, 314 with n. 24 261 The cutting off of the gods from their sacrifices on earth is an old motive, appearing also in the myth of the Hittite gods Kumarbi, Ea and Lama, suggesting a common Indo-European heritage: Lesky $1954,15 \mathrm{f}$. 
of posthumous apotheosis ${ }^{262}$. But again does the tradition lead back at least to the apotheosis of the Hittite emperors, with whom the Etruscan and Roman elites shared a common Indo-European origin from Asia Minor ${ }^{263}$. From the beginning, this 'theological speculation' kept a certain weakness. The very Augustus, who had introduced the Roman ritual and the 'believe' in its validity, warns as divus inter deos in Seneca's Apocolocyntosis, "the Pumkinification", a satirical commentary on the apotheosis of emperor Claudius, who had killed part of his own family to gain power: "Who will worship this god, who will believe in him? Which you make gods of such as he, no one will believe you to be gods" 264 .

262 Aristophanes, Birds 1709-1717; cf. Kavoulaki 2004, 313-315, who interprets Peithetairos' triumphal advent in Cloudcuckooville as first example of an apotheosis in Greek literature. On the Roman Imperial apotheosis: Hiller von Gaertringen 1896; Gradel 2002, 261-371; Zanker 2004. The term apotheosis is first attested only in Strabo 6.3.9 (for Diomedes) and Cicero, Att. 1.16.13, cf. LSc s.v.

263 The apotheosis of the Hittite and Roman emperors delivers an additional argument for the great impact, western Asia Minor had on the development of the Etruscan and subsequently Roman culture, especially that of the elites. The story of Trojan Aeneas founding Rome is a clear hint at people moving from Asia Minor to Italy in the Late Bronze Age and Early Iron Age. This can be backed up by the ancient literary tradition (e.g. Herodotus 1.94: Tyrseno coming from Maionia/Lydia), linguistics (Yakubovitch 2010, $128 \mathrm{f}$. n. 68, p. 159: connection between Etruscan and the language of an inscription found on the island of Lemnos in 1884), as well as recent DNA-analysis of cattle as well as humans: Pellecchia et al. 2007 (Bos taurus); Achilli et al. 2007 (humans from Tuscany); Stoddart 2009, 273-276. It is striking that in Etruscans art the 'Greek' heroes Ajax (Aivas), Achilles (Achile/Achle), Agamemnon (Achmemrun), Heracles (Herkle), Theseus (These) etc. are so popular (see e.g. Steingräber 2002; Bonfante/Bonfante 2002, 192-213 and under the entries in LIMC). This strongly speaks for the existence of the concept of heroes also in the Etruscan culture resp. religion. This is indirectly attested by the Roman authors Servius, Ad Aen. 3.168 (quoting Cornelius Labeo) and Arnobius, Adv. nat. 2.62 who refer to the Etruscan Libri Acheruntici, where the deified souls of the dead (dii animales) recieve animal sacrifices. The Roman authors compared these deified souls with the Penates, the ancestral gods of the Roman househould, they traced back to Troy; cf. Krauskopf 2007, 66. Another association with Asia Minor is to be found in the Manes paterni, di Manes, the anonymous divine souls of the ancestors. The word is etymologically connected to Phrygian Mîv, who originally meant the divine soul of a living person (genius): Latte 1960, $99 \mathrm{f}$. with n. 3. When the Hittite great king Muwatalli II (c. 1310-1282 BC) relocated his capital from Hattuša to Tarhuntašša, he took with him the gods as well as the akkant-, the souls of his dead ancestors: CTH 81 I (§ 6) 75-76, II 1-2; CTH 81II (§ 8) 52-63 (written with the ideogram GIDIM); cf. Doğan-Alparslan/Alparslan 2011, 91 f. with n. 29 (compared with the Roman Manes). For the presumably commun origin of Greek Tritopatores/Tritopator and Roman Tritauos see n. 237

264 Seneca, Apocolocyntosis 10-11: hunc deum quis colet? quis credet? dum tales deos facitis, nome vos deos esse credet. (transl. W.H.D. Rouse); cf. Gradel 2002, 325-336.
The border between heroes and men is on the other hand much more floating, permeable in both directions. This is why, from Late Archaic times on, the number of public hero cults of recently deceased persons, first restricted mainly to founders, starts to grow significantly, now including athletes ${ }^{265}$, Seven Sages (sophoi) like Thales, statesmen like Chares in Miletos, or the poet Archilochos of Paros ${ }^{266}$. In the $5^{\text {th }}$ century, the heroization of living persons is first occuring 267 , reaching its zenith with the cult of Hellenistic rulers ${ }^{268}$. Empedocles (c. 490-430 BC) was not ironical, when even calling himself an "immortal god, not longer mortal, held in honor among all”269. Instead he can be understood as "unquestionable a man with a religious message" ${ }^{270}$, who tried to

265 On the "idolization" of successfull athletes see Parker 2011, $122 \mathrm{f}$. 266 Archilochos: Clay 2004.

267 Graf 1998, 477; Currie 2005, esp. 85-200; Jones 2010, 26 (Hagnon in Amphipolis, $5^{\text {th }}$ century BC), $39 \mathrm{f}$. (Euthymos in Locri, $5^{\text {th }}$ century BC), 93-96 (Dion in Syracuse, Bourichis, Adeimantos and Oxythemis, three of the "flatterers" of Demetrios Poliorketes in Athens, $4^{\text {th }} / 3^{\text {rd }}$ centuries BC; Diodoros Pasparos in Pergamon, Nikias in Kos, $1^{\text {st }}$ century BC, etc.).

268 Habicht 1970. Habicht $(1970,198)$ stresses that though the living rulers got the title $\theta \varepsilon$ ç, they never equaled the gods. Instead, it was believed that in a distinct situation a power similar to the divine power had minifested itself in the ruler. On the close connections between the cult of heroes and ancestors and that of living humans: Habicht 1970, 200-205. Nevertheless, he totally dismisses the idea of the immortal, divine soul as the main reason, why heroes, dead ancestors and living humans (including later the Roman emperors!) could be heroized/divinized. Instead, he stresses "einmalige Leistungen" ("solitary achievements") in favour of Greek cities as main reason (Habicht 1970, 205 n. 51). In an addition to the second edition (Habicht 1970, 268) he adds also "daß die Schranken zwischen dem Göttlichen und dem Menschlichen nach griechischer Auffassung niedriger waren als nach unserem Empfinden und eben im besonderen Fall überschreitbar" ("that according to Greek experience the barriers between the divine and the human were lower than according to our experience, and therefore crossable in certain cases"). This I would certainly doubt. The reason is not that my thinking "entspringt, sicher unbewußt, modernem religiösem Empfinden, das von der monotheistischen Gottesvorstellung, dazu noch vom christlichen Erlösergedanken geprägt ist" ("stems, without doubt unconciously, from a modern religious experience, coined by the monotheistic imagination of god, moreover by the Christian believe in the Saviour", with these words Habicht 1970, 269 critizises Ch. Edson). My doubt instead rests on my confidence in the clear Greek concept of the human soul as immanent divine in every human being.

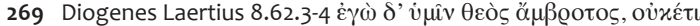

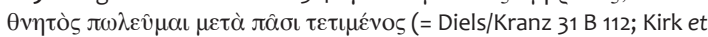
al. 2001, 344 f. no. 399); on the seriousness of Empedokles' claim to be immortal see Kingsley 1995, 220; Tell, 2007, 256.

270 Parker 2011, 256 n. 85. But he values Empedocles and his teacher Pythagoras as "unimportant" for mainland Greece, as "freaks", whose "great interest for the religious history of classical Greece lies perhaps in a negative" (ibid. 255 on Pythagoras). Burkert 2011, 286, in dealing with Empedocles, diagnoses a certain 
reunify gods and men, as they were in the beginning of time, the "Golden Age" of Hesiod ${ }^{271}$, delivering four hundred years later a perfect model for the new Roman emperor Augustus, who - in the Greek East - received godlike honours already during his lifetime, for example in Miletos at the altar of Artemis Boulaia, potentially an Ara Augusti.

In Bacchic-Orphic mystery cults, whose earliest testimonies stem from the main state sanctuary of the Milesian Black Sea colony Olbie Polis/Olbia, the Apollo Delphinios sanctuary ${ }^{272}$, but which are usually downplayed by scholars as 'subculture'273, the divinization of the dead is only testified from the $4^{\text {th }}$ century BC on and seems to remain an exception. But this is merely a matter of our preserved evidence ${ }^{274}$. So does the Derveni-papyrus, completly published only in 1993 and dated around $420 / 400 \mathrm{BC}$, include a commentary of the 'theogony of Orpheus', which is therefore at least of the $5^{\text {th }}$, if not of the $6^{\text {th }}$ century $\mathrm{BC}^{275}$. The high age of this kind of eschatology is not least indicated by the amazing resemblance between the voyage of the BacchicOrphic soul and 'the great voyage' of the Hittite soul276. Again, we may assume a common IndoEuropean tradition, speaking against the theory of the 'un-Greekness' of Orphism²7.

Menekrates, who appeared as Zeus in the $4^{\text {th }}$ century BC as "fast schon ein klinischer Fall" ("already a clinical case").

271 Empedokles: Diels/Kranz 21 B 115-147; cf. Burkert 2011, 445. Maybe this is the reason, why a deified dead is calling himself in a gold lamella from Thurioi "son of Heaven and Earth", or in other words: “a Titan”, see S. Iles-Johnston in: Graf/Iles-Johnston 2007, 115; Bernabé/Jiménez San Cristóbal 2008, 187. Burkert 2011, 444 however sees no compelling reason to combine this with the myth of the Titans. But see his remarks in Burkert 2003, 38-40, where he hints at the role of the seven Titans of the Orphic tradition, sons of Heaven and Earth, banished in the underworld, comparable to the 'old Gods' in the Hurritic-Hittite Kumarbi myth, or to the followers of Tiamat, the bad 'Seven', in the Babylonian Enuma elish.

272 In the Delphinion of Olbie Polis/Olbia were found bone tablets with short Bacchic-Orphic texts of the early $5^{\text {th }}$ century BC: Burkert 2003, 84, 90 f.; Graf/lles-Johnston 2007, 64 f., 163 f., 185-188 nos. 1-2; Coscia 2011. The Delphinion of Olbie Polis included, like the Delphinion in Miletos, the prytaneion of the polis and was the main sanctuary: Herda 2005, 275 f. fig. 27; Herda 2008, 32 with n. 141, p. 35; Herda 2011, 78. It is therefore problematic to view the Orphics of Olbie Polis as marginal 'subculture', as Burkert does (see next note). 273 Cf. e.g. Burkert 2003, 87.

274 Burkert 2011, $438 \mathrm{f}$. on the gold lamellae from Thuriou; see also Graf/Iles-Johnston 2007, 8-15, 114-116, 119, 123 f, 128 on nos. 3-7; Bernabé/Jiménez San Cristóbal 2008, 95-132. Empedocles' doctrine suggests that this believe goes back to at least the $5^{\text {th }}$ century BC. 275 Burkert 2003, $96 \mathrm{f}$. On the Physika of Orpheus for being a $5^{\text {th }}$ century $B C$ theogonic and anthropogonic text see Gagné 2007. 276 Bernabé/Jiménez San Cristóbal 2008, 209-217; cf. above n. 229. 277 Compare the structural and formal parallels between the dialogues of the souls and the guardians and gods of the underworld
Finally, since Hellenistic times, the

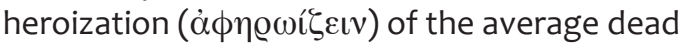
becomes a widespread custom ${ }^{278}$, including the transfer of heroic iconography, e.g. that of the 'Totenmahlreliefs' ${ }^{279}$, so also in Miletos ${ }^{280}$. But this development is not to be mixed up with an invalidation of the titel heros, as it still keeps its religious connotation ${ }^{281}$.

In the same sense we can interprete the iconographic assimilation of Roman emperors as well as grave portraits of average dead to that of gods like luppiter, Venus, Mars, or heroes like Hercules not as ridiculing, or, in the opposite, as identifying them with these gods resp. heroes ${ }^{282}$. This is only what Christian polemics want to make us believe ${ }^{283}$. Instead they can be understood as

in the Bacchic-Orphic gold leaves, and the 'dialogues of immortality' of the Homeric heroes immediately before their duels. The parallels "suggest that the leaves are following the same poetic patterns that inspired the Homeric dialogues. The new ideas and experiences they contain, frequently thought to be un-Greek, will be shown to be shaped in the most traditional Greek formulations and categories." (Herrero de Jáuregui 2011, 271 f.).

278 Burkert 2011b, 167; Parker 2011, 123 with n. 49. The relation between hero-cult and cult of the dead is widely ommitted in ThesCRA II (2004) 125-185 s.v. 3.d. 'Heroisierung und Apotheose' 279 Thönges-Stringaris 1965; Parker 2011, 115 f. with n. 29. Nethertheless is the feasting of the average dead and their relatives a standard part of funeral and grave rites from at least Geometric times on: Burkert 2011, 293, $295 \mathrm{f}$. This is again a decisive argument for the close relationship between hero and ancestor cults. 280 On heroon as term for family graves in Imperial Milesian grave inscriptions: Harter-Uibopuu/Wiedergut forthcoming. 281 As regards the heroization of the dead in Hellenistic times Graf 1998, 477 stresses that this does not attest a "total invalidation of the term [heros]"; see already Rohde 1925, $361 \mathrm{f}$. and more recently Hughes 1999, 170 f. Instead, Fabricius 1999, 71, assumes an "Entwertung" of the term. Kurtz/Boardman 1985, 356 even speak of a "courtesy phrase" ("Höflichkeitsfloskel") regarding the usage of the term heros in Hellenistic grave inscriptions.

282 So e.g. Wrede $1981,158-175$, who incorrectly speaks of "Privatdeifikationen" in case of theomorphic depictions of average dead, mainly libertini.

283 Cf. Tertullian, Ad nationes 1, 10, 26-27 (c. 200 AD) on the Roman grave cult: Quid enim omnino ad honorandos eos facitis, quod non etiam mortuis vestris ex aequo praebeatis? Extruitis dei templa: aeque mortuis templa; extruitis aras deis: aeque mortuis aras; easdem titulis supersribitis litteras, easdem statuis inducitis formas, ut cuique ars aut negotium aut eatasfuit : senex de Saturno, imberbis de Apolline, virgo de Diana figuratur, et miles in Marte et in Vulcano faber ferri consecratur. ("Do you offer anything in their honor that you do not already confer upon your deceased in equal measure? You erect temples to your gods. You erect temples to your dead in equal measure. You build altars to your gods. The same for your dead. You confer the same titles on the gods as on dead. You raise statutes to them in the likeness of their talent, their occupation, or their age. Saturn appears as an old man; Apollo is clean-shaven; Diana is a virgin; Mars is a soldier and Vulcan is an iron smith. It is no wonder that you offer the same sacrifices to the divine and the dead and burn the same incense." [transl. Q. Howe]). 
allegorical depictions of the emperors and the dead, stressing their godlike qualities ${ }^{284}$, they owe to the fact that they participate in the divine via their immortal, divine souls.

\section{Bibliographie}

Achilli et al. 2007

Achilli, A. / Olivieri, A. / Pala, M. / Metspalu, E. /

Fornarino, S. / Battaglia, V. / Accetturo, M. / Kutuev, I. /

Khusnutdinova, E. / Pennarun, E. / Cerutti, N. / Di Gaetano,

C. / Crobu, F. / Palli, D. / Matullo, G. / Santachiara-

Benerecetti, A.S. / Cavalli-Sforza, L.L. / Semino, O. / Villems,

R. / Bandelt, H.-J. / Piazza, A. / Torroni, A., "Mitochondrial

DNA Variation of Modern Tuscans Supports the Near

Eastern Origin of Etruscans", American Journal of Human

Genetics 80, 2007, 759-768 <http://www.ncbi.nlm.nih.gov/

pmc/articles/PMC1852723/> (02.06.2012).

Agelidis 2009

Agelidis, S., "16. Archaische Kore des Anaximandros", in O. Dally et al. (éds.), ZeitRäume. Milet in Kaiserzeit und Spätantike, Exhibition Catalogue, Pergamonmuseum Berlin, 6. Mai 2009 - 10. Januar 2010, Ratisbonne, 2009, 190-191.

\section{Anderson 2009}

Anderson, M.J., "Heroes as Moral Agents and Moral Examples" in S. Albersmeier (éd.), Heroes. Mortals and Myths in Ancient Greece [Exhibition Catalogue Walters Art Museum Baltimore], Baltimore, 2009, 144-173.

Antonaccio 1995

Antonaccio, C., An Archaeology of Ancestors. Tomb Cult and Hero Cult in Early Greece, Lanham / Londres, 1995.

\section{Antonaccio 1999}

Antonaccio, C., "Colonization and the Origins of Hero Cult", in R. Hägg (éd.), Ancient Greek Hero Cult. Proceedings of the Fifth International Seminar on Ancient Greek Cult, organized by the Department of Classical Archaeology and Ancient History, Göteborg University, 21-23 April 1995, Stockholm, 1999, 109-121.

\section{Antonaccio 2006}

Antonaccio, C., "Religion, Basileis and Heroes", in

S. Deger-Jalkotzy / I. Lemos (éds.), Ancient Greece: From the Mycenaean Palaces to the Age of Homer, Edimbourg, 2006, 381-395.

\section{Antonaccio 2011}

Antonaccio, C., "Hero-cult", in M. Finkelberg (éd.), The Homer Encyclopedia Vol. II, Chichester, West Sussex, 2011, 350-351.
Assmann 2009

Assmann, J., "Der Mythos des Gottkönigs im Alten

Ägypten", in C. Schmitz /A. Bettenworth (éds.), Mensch -

Heros - Gott. Weltentwürfe und Lebensmodelle im Mythos der Vormoderne, Stuttgart, 2009, 11-25.

Badian 1997

Badian, E., "Asandros 2", in Der Neue Pauly 2, Stuttgart /

Weimar, 1997, 74.

Bérard 1970

Bérard, C., Eretria III: L'Hérôon à la Porte de l'Ouest, Bern, 1970.

\section{Berges 1986}

Berges, D., Hellenistische Rundaltäre Kleinasiens, Diss.

Freiburg, Breisgau, 1986.

\section{Berges 1996}

Berges, D., Rundaltäre aus Kos und Rhodos, Berlin, 1996.

Bernabé/Jiménez San Cristóbal 2008

Bernabé, A. / Jiménez San Cristóbal, A.I., Instructions for the Netherworld. The Orphic Gold Tablets, Leyde / Boston, 2008.

\section{Berns 2003}

Berns, C., Untersuchungen zu den Grabbauten der frühen Kaiserzeit in Kleinasien [Asia Minor Studien 51], Bonn, 2003.

Betegh 2002

Betegh, G., "Thales", in Der Neue Pauly 12/1, Stuttgart-

Weimar, 2002, 236-238.

Bickel 2009

Bickel, S., "Die Verknüpfung von Weltbild und Staatsbild", in R.G. Kratz (éd.), Götterbilder, Gottesbilder, Weltbilder (Ägypten, Mesopotamien, Persien, Kleinasien, Syrien, Palästina), Tübingen, 2009, 79-102.

Blanck 1997a

Blanck, H., "Anaximander in Taormina", $\operatorname{MDAI}(R) 104$ 1997, 507-511.

Blanck 1997b

Blanck, H., "Un nuovo frammento del catalogo della biblioteca di Tauromenion", PP 52, 1997, 241-255.

Blanck 1999

Blanck, H., "Zum Anaximander-Relief im Museo nazionale romano", in H. von Steuben (éd.), Antike Porträts. Gedenkschrift Helga von Heintze, Möhnesee, 1999, 47-51.

Bol 2011

Bol, R., Funde aus Milet, Teil 2: Marmorskulpturen der römischen Kaiserzeit aus Milet. Aufstellungskontext und programmatische Aussage, Milet V 2, Berlin / New York, 2011.

284 Zanker 2007, 98; Ritter 2009, $186 \mathrm{f.}$ 
Bol/Weber 2011

Bol, R. / Weber, B.F., "V. Heroon an der Theaterbucht", in R. Bol, Funde aus Milet, Teil 2: Marmorskulpturen der römischen Kaiserzeit aus Milet. Aufstellungskontext und programmatische Aussage, Milet V 2, Berlin / New York, 2011, 74-79 figs. 34-39, pl. 31.

\section{Bohringer 1980}

Bohringer, F., "Mégare. Traditions mythiques, espace sacré et naissance de la cité”, AC 49, 1980, 5-22.

Bonfante/Bonfante 2002

Bonfante, G. / Bonfante, L., The Etruscan Language. An Introduction, Manchester / New York, 2002² (1983').

Bravo 2009

Bravo, J.G., "Recovering the Past. The Orrigins of Greek Heroes and Hero Cult" in S. Albersmeier (éd.), Heroes. Mortals and Myths in Ancient Greece [Exhibition Catalogue Walters Art Museum Baltimore], Baltimore, 2009, 10-29.

Brelich 1958

Brelich, A., Gli eroi greci. Un problema storico-religioso, Rome, 1958.

Bringmann/Steuben 1995

Bringmann, K. / Steuben, H. von, Schenkungen

hellenistischer Herrscher an griechische Städte und

Heiligtümer, Teil 1: Zeugnisse und Kommentare, Berlin, 1995.

Brückner et al. 2006

Brückner, H. / Müllenhoff, M. / Gehrels, R. / Herda, A. / Knipping, M. / Vött, A., "From Archipelago to Floodplain - Geographical and Ecological Changes in Miletos and its Environs During the Past Six Millennia (Western Anatolia, Turkey)", Zeitschrift für Geomorphologie N. F., Suppl.-Vol. 142, 2006, 63-83.

Brückner et al. forthcoming

Brückner, H. / Herda, A. / Müllenhoff, M. / Rabbel, W. / Stümpel, H., "On the Lion and Other Harbours in Miletos. Historical, Archaeological, Sedimentological, and Geophysical Investigations", in Proceedings of the Danish Institute at Athens, forthcoming.

Bumke 2009

Bumke, H., "Neue Köpfe für alte Damen. Zeugnisse für die Inszenierung von Tradition und Vergangenheit im griechschen Osten", in R. Einicke et al. (éds.), Zurück zum Gegenstand. Festschrift für Andreas E. Furtwängler, Vol. I, Langenweißbach, 2009, 25-36.

Burgess 2009

Burgess, J., The Death and Afterlife of Achilles, Baltimore, 2009.

Burkert 1961

Burkert, W., “Elysion”, Glotta 39, 1961, 208-213.
Burkert 1984

Burkert, W., Die orientalisierende Epoche in der griechischen Religion und Literatur [Sitzungsberichte der Heidelberger Akademie der Wissenschaften, Philosophisch-historische Klasse, Jahrgang 1984, Bericht 1], Heidelberg, 1984.

Burkert 2003

Burkert, W., Die Griechen und der Orient, Munich, 2003.

Burkert 2011a

Burkert, W., Griechische Religion der archaischen und klassischen Epoche, Stuttgart, 2011² (1977).

Burkert 2011b

Burkert, W., "Griechische Religion”, in Theologische Realenzyklopädie XIV, Berlin-New York, 1985, 235-253 [= in: F. Graf (éd.), Walter Burkert. Kleine Schriften IV. Mythica, Ritualia, Religiosa 1, Göttingen, 2011, 157-185].

Büsing 1978

Büsing, H., "Battos", in Th. Lorenz (éd.), Thiasos. Sieben archäologische Arbeiten, Amsterdam, 1978, 51-79.

Cain/Pfanner 2009

Cain, H.U. / Pfanner, M., "Die Agora Milets in der Kaiserzeit und der Spätantike”, in O. Dally et al. (éds.), ZeitRäume. Milet in Kaiserzeit und Spätantike, Exhibition Catalogue, Pergamonmuseum Berlin, 6. Mai 2009-10. Januar 2010, Ratisbonne, 2009, 82-95.

Calame 2005

Calame, C., "Heracles, Animal and Sacrificial Victim in Sophocles' Trachiniae?”, in R. Hägg / B. Alroth (éds.), Greek Sacrificial Ritual, Olympian and Chthonian [Proceedings of the Sixth International Seminar on ancient Greek Cult, organized by the Department of Classical Archaeology and Ancient History, Göteborg University, 25-27 April 1997], Stockholm, 2005, 181-195.

Camia 2011

Camia, F., Theoi sebastoi. Il culto degli imperatori romani in Grecia (Provincia Achaia) nel secondo secolo D.C.

[Meletēmata 65], Athènes, 2011.

Camp 1986

Camp, J.M., The Athenian Agora. Excavations in the Heart of Classical Athens, Londres, 1986.

Castagnoli 1971

Castagnoli, F., Town Planning in Antiquity, Cambridge, Massachusetts et al., 1971.

Cerchiai 2009

Cerchiai, L., "I codici della communicazione", Aion 31, 2009, 23-28.

Chantraine 1968-1980

Chantraine, P., Dictionnaire étymologique de la langue grecque, Paris, 1968-1980. 
Christes 2001

Christes, J., "Sieben Weise”, Der Neue Pauly 11 (2001), 526 s.v.

\section{Classen 1965}

Classen, C.J., "Thales (1)”, in: Paulys Realencyclopädie der Classischen Altertumswissenschaften, Supplement X, Stuttgart, 1965, 930-947 s.v.

Clinton 1996

Clinton, K., "A New Lex Sacra From Selinous: Kindly Zeuses, Eumenides, Impure and Pure Tritopatores, and Elasteroi", CP 91, 1996, 159-179.

Coldstream 1976

Coldstream, N., "Hero Cults in the Age of Homer", JHS 96, 1976, 8-17.

\section{Cordano 2009}

Cordano, F., "Il luoghi di culto per i fondatori", in M. Boghi Jovino / F. Chiesa (éds.), L'ara della regina di Tarquinia. Aree sacre. Santuari mediterranei, Milan, 2009, 199-207.

Cormack 2004

Cormack, C., The Space of Death in Asia Minor [Wiener

Forschungen zur Archäologie 6], Vienne, 2004

Coscia 2011

Coscia, A., "Gli Orfici Del Mar Nero. Le enigmatiche tavolette ossee scoperte in una antica colonia greca nel Mar Nero ci svelano l'esistenza di una setta che credeva nella reincarnazione", Fenix, 35, settembre 2011. <http://independent.academia.edu/alexcox/ Papers/1397495/Gli_Orfici_del_Mar_Nero> (8.6.2012)

Couprie 2003

Couprie, D., "The Discovery of Space: Anaximander's Astronomy”, in D.L. Couprie / R. Hahn / G. Naddaf (éds.), Anaximander in Context. New Studies in the Origins of Greek Philosophy, New York, 2003, 165-254.

Currie 2005

Currie, B., Pindar and the Cult of Heroes, Oxford, 2005.

Curti/van Bremen 1999

Curti, E. / van Bremen, R., "Notes on the Lex Sacra from Selinous”, Ostraka 8, 1999, 21-33.

Dally/Scholl 2009

Dally, O. / Scholl, A., "Skulptur und Raum", in O. Dally et al. (éds.), ZeitRäume. Milet in Kaiserzeit und Spätantike, Exhibition Catalogue, Pergamonmuseum Berlin, 6. Mai 2009 - 10. Januar 2010, Ratisbonne, 2009, 142-153.

Darsow 1954

Darsow, W., "Die Kore des Anaximandros", JDAI 69, 1954, 101-117 figs. 1-5.
Deoudi 1999

Deoudi, M., Heroenkulte in homerischer Zeit [BAR

International Series 806], Oxford, 1999.

Descat 2010

Descat, R., "Argyrion symmachikon et l'histoire de la Carie à la fin du IVe S. a.C.", in R. van Bremen / J.-M. Carbon (éds.), Hellenistic Karia [Proceedings of the First International Conference on Hellenistic Karia, Oxford, 29 June-2 July 2006], Bordeaux, 2010, 133-144.

Diels/Kranz 1974

Diels, H. / Kranz, W., Die Fragmente der Vorsokratiker. Griechisch und deutsch, Vol. I, Berlin, ${ }^{17} 1974$.

Doğan-Alparslan/Alparslan 2011

Doğan-Alparslan, M. / Alparslan, M., "Wohnsitze und Hauptstädte der hethitischen Könige”, $\operatorname{MDAI}(I) 61,2011$, 85-103.

Dyggve et al. 1934

Dyggve, E. / Poulsen, F. / Rhomaios, K., Das Heroon von Kalydon, Copenhague, 1934.

Ecole Suisse 2004

Ecole Suisse d'Archéologie en Grèce (éd.), Eretria. A Guide to the ancient City, Fribourg, 2004.

Ehrhardt 1993

Ehrhardt, N., "Zwei archaische Statuen mit NymphenWeihungen aus Milet", EA 21, 1993, 3-8.

Ehrhardt/Günther 2010

Ehrhardt, N. / Günther, W., "Neue Grabinschriften aus Milet", Chiron 40, 2010, 397-426.

Ekroth 2002

Ekroth, G., The Sacrificial Rituals of Greek Hero-Cults in the Archaic to the early Hellenistic Periods [Kernos Supplement 12], Liège, 2002.

Ekroth 2009

Ekroth, G., "The Cult of Heroes" in S. Albersmeier (éd.), Heroes. Mortals and Myths in Ancient Greece [Exhibition Catalogue Walters Art Museum Baltimore], Baltimore, 2009, 120-143.

Fabricius 1999

J. Fabricius, Griechische Totenmahlreliefs.

Grabrepräsentation und Wertvorstellungen in ostgriechischen Städten, Munich, 1999.

Faraone 1992

Faraone, C., Talismans and Trojan Horses. Guardian Statues in Ancient Greek Myth and Ritual, New York / Oxford 1992.

Farnell 1921

Farnell, L.R., Greek Hero Cults and Ideas of Immortality, Oxford, 1921. 
Fittschen 1988

Fittschen, K., "Griechische Poträts - Zum Stand der Forschung”, in idem (éd.), Griechische Porträts, Darmstadt, $1988,1-38$

Forbeck 2001/2002

Forbeck, E., “Die Nekropolen von Milet. Grabtypologie und Bestattungsbräuche von vorarchaischer bis römischer Zeit", in H. Iskan / F. Işık (éds.), Grabtypen und Totenkult im südwestlichen Kleinasien [Lykia 6], 2001/2002, 55-64.

Forbeck 2002

Forbeck, E., "Gräber des hellenistischen und kaiserzeitlichen Milet" in C. Berns / L. Vandeputt (éds.), Patris und Imperium. Kulturelle und politische Identität in den Städten der römischen Provinzen Kleinasiens in der frühen Kaiserzeit. Kolloquium Köln, November 1998 [BABesch Suppl. 8], 2002, 97-105.

Forbeck forthcoming

Forbeck, E., Die Nekropolen von Milet, forthcoming.

Forbeck/Heres 1997

Forbeck, E. / Heres, H., Das Löwengrab von Milet, Winckelsmannprogramm der Archäologischen Gesellschaft zu Berlin 136, Berlin, 1997.

Fougéres 1898

Fougéres, G., Mantinée et l'Arcadie orientale, Paris, 1898.

Frederiksen 2011

Frederiksen, R., Greek City Walls of the Archaic Period. 900480 BC, Oxford, 2011.

Frisone 2011

Frisone, F., "Construction of Consensus. Norms and Change in Greek Funeral Rituals", in A. Chaniotis (éd.), Ritual Dynamics in the Ancient Mediterranean: Agency, Emotion, Gender, Reception, Stuttgart, 2011, 179-201.

Furtwängler 1905

Furtwängler, A., “Die Giebelgruppen des alten Hekatompedon auf der Akropolis zu Athen", SBMünchen $1905,433-466$.

Gallou 2005

Gallou, Ch., The Mycenaean Cult of the Dead [BAR International Series 1372], Oxford, 2005.

Gagné 2007

Gagné, R., "Winds and Ancestors: The Physika of

Orpheus", HSPh 103, 2007, 1-23.

\section{Geagan 2011}

Geagan, D.A., The Athenian Agora XVIII: Inscriptions: The Dedicatory Monuments, Princeton, NJ, 2011.

Gehrke 2007

Gehrke, H.-J., "Die Raumwahrnehmung im archaischen

Griechenland", in M. Rathmann (éd.), Wahrnehmung und
Erfassung geographischer Räume in der Antike, Mayence, 2007, 17-30.

Georgoudi 2001

Georgoudi, S., “'Ancêtres' de Selinonte et d'ailleurs: le cas des Tritopatores”, in G. Hoffmann / A. Lezzi-Hafter (éds.), Les pierres de l'offrande. Autour de l'œuvre de Christophe Clairmont, Zürich, 2001, 152-163.

Gerkan 1925

Gerkan, A. von, Kalabaktepe, Athenatempel und Umgebung, Milet I 8, Berlin, 1925.

Gerkan 1935

Gerkan, A. von, Die Stadtmauern, Milet II 3, Berlin / Leipzig, 1935.

Gorman 2001

Gorman, V., Miletos, the Ornament of Ionia. A History of the City to 400 B.C.E., Ann Arbor, 2001.

Gradel 2002

Gradel, I., Emperor Worship and Roman Religion, Oxford, 2002.

Graeve 1986

Graeve, V. von, “1 b. Der Grabnaiskos aus dem Heroon I", $\operatorname{MDAl}(I) 36,1986,8-12$ pl. 2.

Graeve 2006

Graeve, V. von, “Milet”, in W. Radt (éd.), Stadtgrabungen und Stadtforschungen im westlichen Kleinasien. Geplantes und Erreichtes, Internationales Symposion, 6./7. August 2004 in Bergama (Türkei), Istanbul, 2006, 241-262.

Graeve 2009

Graeve, V. von., "Milet in archaischer Zeit", in O. Dally / M. Maischberger / P. Schneider / A. Scholl (éds.), ZeitRäume. Milet in Kaiserzeit und Spätantike, Exhibition Catalogue, Pergamonmuseum Berlin, 6. Mai 2009 - 10. Januar 2010, Regensburg, 2009, 24-27.

Graf 1998

Graf, F., "Heroenkult”, in Der Neue Pauly 5, Stuttgart, 1998, 476-480 s.v.

Graf/Iles-Johnston 2007

Graf, F. / Iles-Johnston, S., Ritual Texts for the Afterlife. Orpheus and the Bacchic Gold Tablets, Londres / New York, 2007.

Graham/Hintz 2007

Graham, D.W. / Hintz, E., "Anaxagoras and the Solar Eclipse of 478 BC”, Apeiron 40, 2007, 319-344.

Greco/Theodorescu 1983

Greco, E. / Theodorescu, D., Poseidonia - Paestum II: L'agora [Collection de l'École Française de Rome 42], Rome, 1983. 
Günther 1989

Günther, W., "Die Anfänge des Kaiserkults in Milet”, $\operatorname{MDAl}(I) 39,1989,173-178$.

Haas 1994

Haas, V., Geschichte der hethitischen Religion [Handbook of Oriental Studies, Vol. 15], Leyde et al., 1994.

Habicht 1970

Habicht, C., Gottmenschentum und griechische Städte

[Zetemata 14], Munich, $1970^{2}$ (1956').

Hahn 1994

Hahn, U., Die Frauen des römischen Kaiserhauses und ihre Ehrungen im griechischen Osten anhand epigraphischer und numismatischer Zeugnisse von Livia bis Sabina [Saarbrücker Studien zur Archäologie und Alten Geschichte 8],

Saarebruck, 1994.

Hahn 2001

Hahn, R., Anaximander and the Architects. The Contribution of Egyptian and Greek Architectural Technologies to the Origins of Greek Philosophy, Albany, 2001.

Hahn 2003

Hahn, R., "Proportions and Numbers in Anaximander and Early Greek Thought", in D.L. Couprie / R. Hahn / G. Naddaf (éds.), Anaximander in Context. New Studies in the Origins of Greek Philosophy, New York, 2003, 71-163.

Hahn 2010

Hahn, R., Archaeology and the Origins of Philosophy, New York, 2010

Haider 2004

Haider, P. W., "Kontakte zwischen Griechen und Ägyptern und ihre Auswirkungen auf die archaisch-griechische Welt", in R. Rollinger / C. Ulf (éds.), Griechische Archaik. Interne Entwicklungen - Externe Impulse, Berlin, 2004, 447-491.

Hanell 1934

Hanell, K., Megarische Studien, Lund, 1934.

Hardie 1985

Hardie, P., "Imago Mundi: Cosmological and Ideological Aspects of the Shield of Achilles", JHS 105, 1985, 11-31.

Harding 2008

Harding, P., The Story of Athens: The Fragments of the Local Chronicles of Attika, Oxon / New York, 2008.

Harrison 1908

Harrison, J.E., Prolegomena to the Study of Greek Religion, Cambridge, $1908^{2}\left(1903^{1}\right)$.

Harrison 1912

Harrison, J.E., Themis. A Study of the Social Origins of Greek Religion, Cambridge, 1912.
Harter-Uibopuu/Wiedergut forthcoming

Harter-Uibopuu, K. / Wiedergut, K., “'Niemand anderer soll hier bestattet werden' - Grabschutz im kaiserzeitlichen Milet", in H. Thür (éd.), Akten der Tagung des ZAA, Vienne, forthcoming. <http://oeaw.academia.edu/ KajaHarterUibopuu/Papers/1527820/_Kein_anderer_ soll_hier_bestattet_werden___Grabschutz_im_ kaiserzeitlichen_Milet_in_G.Thur_Ed._Akten_der_ Tagung_des_ZAA_Wien_2012_in_print> (03.06.2012)

Haselberger 1999

Haselberger, L., "Geometrie der Winde, windige Geometrie: Städtebau nach Vitruv und Aristophanes", in E.L. Schwandner / K. Rheidt (éds.), Stadt und Umland. Neue Ergebnisse der archäologischen Bau- und Siedlungsforschung, Bauforschungskolloquium in Berlin vom 7. bis 10. Mai 1997, veranstaltet vom ArchitekturReferat des DAI [Diskussionen zur Archäologischen Bauforschung 7], Mayence, 1999, 90-100.

Haubold 2005

Haubold, J., "The Homeric Polis”, in M.H. Hansen (éd.), The Imaginary Polis. Symposium, January 7-10, 2004 [Acts of the Copenhagen Polis Center Vol. 7], Copenhague, 2005, 25-48.

Hawkins 1995

Hawkins, J. D., The Hieroglyphic Inscription of the Sacred Pool Complex at Hattusa (Südburg). With an Archaeological Introduction by Peter Neve, Wiesbaden, 1995.

Hawkins 2000

Hawkins, J.D., Corpus of the Hieroglyphic Luwian Inscriptions, Vol. I: Inscriptions of the Iron Age 1-3, Berlin / New York, 2000.

Hellmann 2001

Hellmann, M.-C., "Hippodamos”, in R. Vollkommer (éd.), Künstlerlexikon der Antike 1, Munich / Leipzig, 2001, 321-325.

Hellner 2004

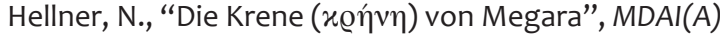
119, 2004, 163-220.

Hemberg 1954

Hemberg, В., “ТITOПАТ $\Omega$ P and TPI $\Sigma H P \Omega \Sigma$.

Griechischer Ahnenkult in klassischer und mykenischer Zeit", Eranos 52, 1954, 172-190.

Henrichs 2005

Henrichs, A., "'Sacrifice as to the Immortals'. Modern Classifications of Animal Sacrifice and Ritual Distinctions in the Lex Sacra from Selinous", in R. Hägg / B. Alroth (éds.), Greek Sacrificial Ritual, Olympian and Chthonian. Proceedings of the Sixth International Seminar on ancient Greek Cult, organized by the Department of Classical 
Archaeology and Ancient History, Göteborg University, 25-27 April 1997, Stockholm, 2005, 47-60.

Herda 1998

Herda, A., "Der Kult des Gründerheroen Neileos und die Artemis Kithone in Milet”, JÖAI 88, 1998, Beiblatt 1-48.

Herda 2005

Herda, A., "Apollon Delphinios, das Prytaneion und die Agora von Milet. Neue Forschungen", AA 2005/1, 243-294.

Herda $2006 a$

Herda, A., Der Apollon-Delphinios-Kult in Milet und die Neujahrsprozession nach Didyma. Ein neuer Kommentar der sog. Molpoi-Satzung [Milesische Forschungen 4], Mayence, 2006.

Herda 2006b

Herda, A., "Panionion - Melia, Mykalessos Mykale, Perseus und Medusa. Überlegungen zur Besiedlungsgeschichte der Mykale in der frühen Eisenzeit", $\operatorname{MDAI}(I)$ 56, 2006, 43-102.

Herda 2008

Herda, A., "Apollon Delphinios - Apollon Didymeus: Zwei Gesichter eines milesischen Gottes und ihr Bezug zur Kolonisation Milets in archaischer Zeit”, in R. Bol / U. Höckmann / P. Schollmeyer (éds.), Cultural contacts. Apollo in Myus, Miletus/Didyma, Naucratis and on Cyprus [Proceedings of the Round Table in Mayence, $11^{\text {th }}-12^{\text {th }}$ of March 2004], Rhaden, 2008, 13-86.

Herda 2009

Herda, A., "Karkiša-Karien und die sog. Ionische Migration", in F. Rumscheid (éd.), Die Karer und die Anderen [Internationales Kolloquium an der Freien Universität Berlin, 13. bis 15. Oktober 2005], Bonn, 2009, 27-108.

Herda 2011

Herda, A., "How to Run a State Cult. The Organization of the Cult of Apollo Delphinios in Miletos", in M. Haysom / J. Wallensten (éds.), Current Approaches to Religion in Ancient Greece [Papers Presented at a Symposium at the Swedish Institute at Athens, 17-19 April 2008], Athènes, 2011, 57-93.

Herda 2012

Herda, A., "Soul and Kosmos. Menelaos and the shield of Euphorbos in Didyma”, in V. Bers et al. (éds.), Donum natalicum confectum Gregorio Nagy septuagenario a discipulis collegis familiaribus oblatum. A Virtual Birthday Gift Presented to Gregory Nagy on Turning Seventy by His Students, Colleagues, and Friends <http://chs.harvard.edu/wa/pageR?tn=ArticleWrapper\& $\mathrm{bdc}=12 \& \mathrm{mn}=4804>(28.10 .2012)$.
Herda forthcoming a

Herda, A., From Anax to Thales: Miletos in Asia/Ionia and Its Many Founders from Neolithic to Roman Times. An Interdisciplinary Experiment [Center for Hellenic Studies Series], Harvard University Press, forthcoming.

Herda forthcoming $b$

Herda, A., "Greek (and Our) Views on the Karians", in A. Mouton / I. Rutherford / I. Yakubovitch (éds.), Luwian Identities: Culture, Language and Religion Between Anatolia and the Aegean, Reading University, Department of Classics, 10 - 11 June 2011, forthcoming.

Herda forthcoming $c$

Herda, A., "Megara and Miletos: Colonizing with Apollo" in A. Robru / I. Birsezcu (éds.), Mégarika. Nouvelles recherches sur les cités de la Mégaride et les foundations mégariennes du Pont Euxin: Archéologie, épigraphie, histoire [Colloque internationale organize par Institutul Arkeologie 'Vasile Parvan', Academia Româna, et Collège de France, 8-12 Juillet 2012, Mangalia (Roumanie)], forthcoming.

Herda in preparation

Herda, A., Thales or Hippodamus? Agora and Townplanning in Miletus before and after the Persian Wars (in preparation).

Herda/Sauter 2009

Herda, A. / Sauter, E., "Karerinnen und Karer in Milet: Zu einem spätklassischen Schüsselchen mit karischem Graffito aus Milet", AA 2009, 51-112.

Herrero de Jáuregui 2011

Herrero de Jáuregui, M., "Dialogues of Immortality from the Iliad to the Gold Leaves", in R.G. Edmonds III (éd.), The 'Orphic' Gold Tablets and Greek Religion. Further along the Path, Cambridge / New York, 2011, 271-290.

Herrmann 1980

Herrmann, P., "Kaiserzeitliche Grabinschriften mit Stephanephoren-Daten", in W. Müller-Wiener (éd.), Milet 1978-1979, MDAI(I) 30, 1980, 92-98.

Herrmann 1987 Herrmann, P., “Milesier am Seleukidenhof. Prosopographische Beiträge zur Geschichte Milets im 2. Jhdt. v. Chr.", Chiron 17, 1987, 171-192.

Herrmann 1989

Herrmann, P., “Ein Tempel für Caligula in Milet?”, $\operatorname{MDAI}(I)$ 39, 1989, 191-196.

Herrmann 1994 Herrmann, P., "Milet unter Augustus. C. Iulius Epikrates und die Anfänge des Kaiserkults", $\operatorname{MDAI}(I)$ 44, 1994, 203-236. 
Herrmann 1995

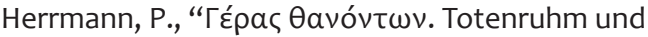
Totenehrung im städtischen Leben der hellenistischen Zeit”, in M. Wörrle / P. Zanker (éds.), Stadtbild und Bürgerbild im Hellenismus, Kolloquium, München, 24. bis 26. Juni 1993 [Vestigia 47], Munich, 1995, 189-197.

Herrmann 1996

Herrmann, P., “Milet unter Augustus. Erkenntnisse aus einem Inschriftenneufund", in J.H.M. Strubbe / R.A. Tybout / H.J. Versnel (éds.), ENEPГEIA. Studies in Ancient History and Epigraphy presented to H.W. Pleket, Amsterdam, 1996, 1-18

Herrmann 1997

Herrmann, P., Inschriften von Milet Teil 1. A. Inschriften n. 187-406 von Albert Rehm mit einem Beitrag von Hermann Dessau, B. Nachträge und Übersetzungen zu den Inschriften n. 1-406 von Peter Herrmann, Milet VI 1, Berlin / New York, 1997.

Herrmann 1998

Herrmann, P., Inschriften von Milet Teil 2. Inschriften n. 4071019, Milet IV 2, Berlin / New York, 1998.

Herrmann et al. 2006

Herrmann, P. / Günther, W. / Ehrhardt, N., Inschriften von Milet Teil 3. Inschriften n. 1020-1580, Milet IV 3, Berlin / New York, 2006.

Highbarger 1927

Highbarger, E.L., The History and Civilization of Ancient

Megara, Part One, Baltimore, 1927.

Hiller von Gaertringen 1896

Hiller von Gaertringen, F., "Apotheosis”, in Paulys

Realencyclopädie der Classischen Altertumswissenschaften II.1, 1896, 184-188 s.v.

Himmelmann 2009

Himmelmann, N., Der Ausruhende Herakles [NordrheinWestfälische Akademie der Wissenschaften und Künste, Geisteswissenschaften, Vorträge G 420], Paderborn et al., 2009.

Hirsch 2001

Hirsch, B., "Orte des Dionysos - Kultplätze und ihre

Funktion”, MDAI (I) 51, 2001, 217-272.

Hölscher 1998

Hölscher, T., Öffentliche Räume in frühen griechischen

Städten [Schriften der Philosophisch-historischen Klasse der Heidelberger Akademie der Wissenschaften, Bd. 7], Heidelberg, 1998.

Hoepfner 2011

Hoepfner, W., Ionien - Brücke zum Orient, Stuttgart /

Darmstadt, 2011.
Hommel 1976

Hommel, H., "Ein König aus Milet. Fragment einer milesischen Weihinschrift (1969)”, Chiron 6, 1976, 319-327.

Hübner 2000

Hübner, W., "Meton [2]", in Der Neue Pauly 8, Stuttgart, 2000, 107 f. s.v.

Hughes 1999

Hughes, D.D., "Hero Cult, Heroic Honors, Heroic Dead: Some Developments in the Hellenistic and Roman Periods", in R. Hägg (éd.), Ancient Greek Hero Cult [Proceedings of the Fifth International Seminar on Ancient Greek Cult, organized by the Department of Classical Archaeology and Ancient History, Göteborg University, 21-23 April 1995], Stockholm, 1999, 167-175. Hutter 2003 Hutter, M., "Aspects of Luwian Religion" in C.H. Melchert (éd.), The Luwians [Handbook of Oriental Studies I 68], Leyde / Boston, 2003, 211-280.

Icard-Gianolio 1994

Icard-Gianolio, N., "Proteus", in LIMC VII 1, Zurich / Munich, 1994, 560-561 s.v.

lles-Johnston 1999

Iles-Johnston, S., Restless Dead: Encounters Between the Living and the Dead in Ancient Greece, Berkeley / Los Angeles, 1999.

Jacoby 1944

Jacoby, F., "Genesia: a Forgotten Festival of the Dead", CQ 38, 1944, 65-75.

Jameson et al. 1993

Jameson, M.H. / Jordan, D.R. / Kotansky, R.D., A Lex Sacra from Selinous, Durham, North Carolina, 1993.

Janda 2005

Janda, M., Elysion. Entstehung und Entwicklung der griechischen Religion, Innsbruck, 2005.

Jeffery 1990

Jeffery, L.H., The Local Scripts of Archaic Greece. Revised Edition with a Supplement by A.W. Johnston, Oxford, 1990

Jones 1992

Jones, C.P., "Hellenistic History in Chariton of

Aphrodisias", Chiron 22, 1992, 91-102.

Jones 2010

Jones, C.P., New Heroes in Antiquity. From Achilles to Antinoos, Cambridge, MA / Londres, 2010.

Kader 1995

Kader, I., "Heroa und Memorialbauten", in M. Wörrle / P. Zanker (éds.), Stadtbild und Bürgerbild im Hellenismus, Kolloquium, München, 24. bis 26. Juni 1993 [Vestigia 47], Munich, 1995, 199-229. 
Kalliontzis/Papazarkadas 2013

Kalliontzis, Y. / Papazarkadas, N., "Tritopatreis in Boeotia”, ZPE 184, 2013, 165-171.

Kaminski 1991

Kaminski, G., "Thesauros. Untersuchungen zum antiken Opferstock”, JDAl 106, 1991, 63-181.

Kantiréa 2007

Kantiréa, M., Les dieux et les dieux augustes. Le culte impérial en Grèce sous les Julio-claudiens et les Flaviens; études épigraphiques et archéologiques, Athènes, 2007.

Karakasi 2001

Karakasi, K., Archaische Koren, Munich, 2001.

Karanastassis 2002

Karanastassis, P., "Hocharchaische Plastik", in P.C. Bol (éd.), Die Geschichte der antiken Bildhauerkunst I: Frühgriechische Plastik, Mayence, 2002, 171-221.

Kavoulaki 2004

Kavoulaki, A., "Processional Performance and the Polis", in S. Goldhill / R. Osborne (éds.), Performance Culture and Athenian Democracy, Cambridge, 2004 (Reprint of 1999'), 293-320.

Kawerau/Rehm 1914

Kawerau, G. / Rehm, A., Das Delphinion in Milet, Milet I 3, Berlin, 1914.

Kekule 1900

Kekule von Stradonitz, R., "Vorläufiger Bericht über die von den Königlichen Museen begonnenen Ausgrabungen in Milet", Sitzungsberichte der königlich-preussischen Akademie der Wissenschaften Berlin 1900, 104-115.

Kerkhecker 1999

Kerkhecker, A., Callimachus. Book of lambi, Oxford, 1999.

Kienast 1995

Kienast, H., Die Wasserleitung des Eupalinos auf Samos, Samos XIX, Bonn, 1995.

Kingsley 1995

Kingsley, P., Ancient Philosophy, Mystery, and Magic:

Empedocles and Pythagorean Tradition, Oxford, 1995.

Kirk et al. 2001

Kirk, G.S. / Raven, J.E. / Schofield, M., Die vorsokratischen Philosophen. Einführung, Texte und Kommentare, Stuttgart-Weimar, 2001.

Kleiner 1968

Kleiner, G., Die Ruinen von Milet, Berlin, 1968.

Kleiner/Müller-Wiener 1972

Kleiner, G. / Müller-Wiener, W., "Die Grabung in Milet im Herbst 1959”, $\operatorname{MDAI}(I) 22,1972,45-92$.

Knackfuß 1908

Knackfuß, H., Das Rathaus von Milet, Milet I 2, Berlin, 1908.
Knigge 1988

Knigge, U., Der Kerameikos von Athen. Führung durch Ausgrabungen und Geschichte, Athènes, 1988.

Knigge 2006

Knigge, U., "Ein Grabmonument der Alkmeoniden im Kerameikos”, $\operatorname{MDAI}(\mathrm{A})$ 121, 2006, 127-163.

Köster 2004

Köster, R., Die Bauornamentik von Milet, Teil 1: Die Bauornamentik der frühen und mittleren Kaiserzeit, Milet VII 1, Berlin, 2004.

Koukouli-Chrysanthaki 2002

Koukouli-Chrysanthaki, Ch., "Excavating Classical Amphipolis", in M. Stamatopoulou / M. Yeroulanou (éds.), Excavating Classical Culture. Recent Archaeological Discoveries in Greece [BAR International Series 1031], Londres, 2002, 57-73.

Krauskopf 2007

Krauskopf, I., "The Grave and beyond in Etruscan Religion", in N. Thomson de Grummond / E. Simon (éds.), The Religion of the Etruscans, Austin, 2007, 66-89.

Kretschmer 1920

Kretschmer, P., "Mythische Namen. 6. Tritogeneia und Tritopatoren", Glotta 11, 1921, 39-45.

Kriegenherdt 1995

Kriegenherdt, A., "B 11: Kore des Anaximandros aus Milet", in K. Stemmer (éd.), Standorte. Kontext und Funktion antiker Skulptur, Exhibition Catalogue AbgussSammlung antiker Plastik Berlin, 27.11.1994-11.6.1995, Berlin, $1995,108 \mathrm{f}$

Kron 1971

Kron, U., "Zum Hypogäum von Paestum”, JDAI 86, 1971, 117-148.

Kron 1976

Kron, U., Die zehn attischen Phylenheroen. Geschichte, Mythos, Kult und Darstellungen [MDAI(A) Beiheft 5], Berlin, 1976.

Kron 1999

Kron, U., “Patriotic Heroes”, in R. Hägg (éd.), Ancient Greek Hero Cult [Proceedings of the Fifth International Seminar on Ancient Greek Cult, organized by the Department of Classical Archaeology and Ancient History, Göteborg University, 21-23 April 1995], Stockholm, 1999, 61-83.

Kübler 1973

Kübler, K., "Eine archaische Grabanlage vor dem Heiligen Tor und ihre Deutung”, AA 1973, 172-193. 
Kurtz/Boardman 1985

Kurtz, D. / Boardman, J., Thanatos. Tod und Jenseits bei den Griechen, Mayence, 1985.

Laroche 1960

Laroche, E., Les Hiéroglyphes Hittites, première partie, Paris, 1960.

Larson 1995

Larson, J., Greek Heroine Cults, Madison, WI, 1995.

Latte 1960

Latte, K., Römische Religionsgeschichte [Handbuch der Altertumswissenschaften V 4], Munich, 1960.

Leschhorn 1984

Leschhorn, W., Gründer der Stadt. Studien zu den politischreligiösen Phänomenen der griechischen Geschichte

[Palingenesia 20], Stuttgart, 1984.

Lesky 1954

Lesky, A., "Zum hethitischen und griechischen Mythos", Eranos 52, 1954, 8-17.

Lippold 1911

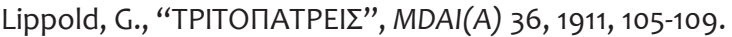

Lolos 2011

Lolos, Y.A., Land of Sikyon. Archaeology and History of a Greek City State [Hesperia Suppl. 39], Princeton, NJ, 2011.

Lupu 2005

Lupu, E., Greek Sacred Law. A Collection of New Documents (NGSL), Leyde / Boston, 2005.

Lyons 1997

Lyons, D.J., Gender and Immortality. Heroines in Ancient

Greek Myth and Cult, Princeton, NJ, 1997.

Mangoldt 2012

Mangoldt, H. von, Makedonische Grabarchitektur. Die makedonischen Kammergräber und ihre Vorläufer, Tübingen / Berlin, 2012.

Mangoldt forthcoming

Mangoldt, B. von, Griechische Heroenkultstätten in klassischer und hellenistischer Zeit. Untersuchungen zu ihrer äußeren Gestaltung, Ausstattung und Funktion, forthcoming.

\section{Marcellesi 2004}

Marcellesi, M.-C., Milet des Hécatomnides à la domination romaine. Pratiques monétaires et histoire de la cité du IVe au II siècle av. J.-C. [Milesische Forschungen 3], Mayence, 2004.

\section{Martin 1993}

Martin, R., "The Seven Sages as Performers of Wisdom", in C. Dougherty / L. Kurke (éds.), Cultural Poetics in Archaic Greece: Cult, Performance, Politics, Cambridge, MA / New York, 1993, 108-128.
Martini 1990

Martini, W., Die archaische Plastik der Griechen, Darmstadt, 1990.

\section{Mattusch 1995}

Mattusch, C.C., "The Eponymous Heroes: The Idea of Sculptural Groups", in W.D.E. Coulson / O. Palagia / T.L. Shear, Jr. / H.A. Shapiro / F.J. Frost (éds.), The Archaeology of Athens and Attica under the Democracy, Proceedings of an International Conference celebrating 2500 years since the birth of democracy in Greece, held at the American School of Classical Studies at Athens, December 4-6, 1992 [Oxbow Monograph 34], Oxford, 1994, 73-81.

Mayor 2000

Mayor, A., The First Fossil Hunters. Palaeontology in Greek and Roman Times, Princeton, NJ, 2000.

Mazerakis Ainian 1987

Mazerakis Ainian, A., "Geometric Eretria”, AK 30, 1987, 3-24.

Mazarakis Ainian 2004

Mazarakis Ainian, A., "1. From the Beginnings to the Archaic Age. Hero Cults of Homeric Society", in ThesCRA II (2004) 131-140 s.v. 3.d. 'Heroisierung, Apotheose'.

Mazarakis Ainian/Leventi 2009

Mazarakis Ainian, A. / Leventi, I., "The Aegean”, in K.A. Raaflaub / H. van Wees (éds.), A Companion to Archaic Greece, Chichester, West Sussex, 2009, 212-238.

McCauley 1999

Barbara McCauley, "Heroes and Power: The Politics of Bone Transferal”, in R. Hägg (éd.), Ancient Greek Hero Cult [Proceedings of the Fifth International Seminar on Ancient Greek Cult, organized by the Department of Classical Archaeology and Ancient History, Göteborg University, 21-23 April 1995], Stockholm, 1999, 85-98.

Meier-Brügger 2006

Meier-Brügger, M., "The Rise and Descent of the Language of the Homeric Poems", in S. Deger-Jalkotzy / I. Lemos (éds.), Ancient Greece: From the Mycenaean Palaces to the Age of Homer, Edimbourg, 2006, 417-426.

Meiggs/Lewis 1969

Meiggs, R. / Lewis, D., A Selection of Greek Historical Inscriptions to the End of the Fifth Century B.C., Oxford, 1969.

Meritt/Traill

Meritt, B.D. / Traill, J.S., The Athenian Agora XV: Inscriptions of the Athenian Councillors, Princeton, NJ, 1974.

Mertens 2006

Mertens, D., Städte und Bauten der Westgriechen. Von der Kolonisationszeit bis zur Krise um 400 vor Christus, Munich, 2006. 
Mertens 2008

Mertens, D., “L'heroon sull'agora di Selinunte. Nota preliminare", in G. Bartolini / G. Benedettini (éds.), Sepolti tra i vivi. Buried among the Living. Evidenza ed interpretazione di contesti funerari in abitato. Atti del convegno internazionale, Roma, 26-29 aprile 2006 [Scienza dell'antichità 14/1], Rome, 2008, 473-487.

Mertens 2010

Mertens, D., “Von Megara nach Selinunt. Raumordnung und Baukunst als Mittel zur Identitätsbildung griechischer Poleis während der Großen Kolonisation", $\operatorname{MDAI}(R) 116$, 2010, 55-103.

\section{Mikalson 1998}

Mikalson, J.D., Religion in Hellenistic Athens, Berkeley / Los Angeles / Londres, 1998.

Miller 1978

Miller, S., The Prytaneion. Its Function and Architectural Form, Berkeley / Los Angeles / Londres, 1978.

Müllenhoff et al. 2009a

Müllenhoff, M. / Herda, A. / Brückner, H., "Geoarchaeology in the City of Thales. Deciphering Palaeogeographic Changes in the Agora Area of Miletos", in T. Mattern/ A. Vött (éds.), Mensch und Umwelt im Spiegel der Zeit. Aspekte geoarchäologischer Forschungen im östlichen Mittelmeergebiet. Philippika [Marburger Altertumskundliche Abhandlungen 1], Wiesbaden, 2009, 97-110.

Müllenhoff et al. 2009b

Müllenhoff, M. / Herda, A. / Brückner, H., “Auf Meersand gebaut - Landschaftswandel in Milet im Spiegel geoarchäologischer Zeugnisse", in O. Dally / M. Maischberger / P. Schneider / A. Scholl (éds.), ZeitRäume. Milet in Kaiserzeit und Spätantike, Exhibition Catalogue, Pergamonmuseum Berlin, 6. Mai 2009 - 10. Januar 2010, Regensburg, 2009, 18-23.

Müller-Wiener 1977-78

Müller-Wiener, W., "Milet 1973-1975. I. Michaelskirche und Dionysostempel. Baubefunde und Phasengliederung", $\operatorname{MDAI}($ I) 27-28, 1977-78, 94-103.

Müller-Wiener 1979

Müller-Wiener, W., “Milet 1977. 1. a) Untersuchungen im Dionysos-Heiligtum”, $\operatorname{MDAI}(I)$ 29, 1979, 162-169.

Müller-Wiener 1988

Müller-Wiener, W., "Untersuchungen im Bischofspalast in Milet (1977-1979)”, $\operatorname{MDAI}(I) 38,1988,279-290$.

Naddaf 2003

Naddaf, G., "Anthropogony and Politogony in Anaximander of Miletus", in D.L. Couprie / R. Hahn / G. Naddaf (éds.), Anaximander in Context. New Studies in the Origins of Greek Philosophy, New York, 2003, 9-69.
Nagy 1999

Nagy, G., The Best of the Achaeans. Concepts of the Hero in Archaic Greek Poetry, Baltimore, 1999 (revised 1979').

Nagy 2010

Nagy, G., “'The Origins of Greek Poetic Language', Review of M.L. West, Indo-European Poetry and Myth (Oxford, 2007)", CR 60, 2010, 333-338.

Nagy $2011 a$

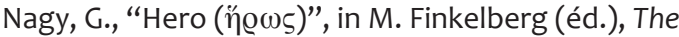
Homer Encyclopedia Vol. II, Chichester, West Sussex, 2011, 348-350 s.v.

Nagy 2011b

Nagy, G., Homer the Classic, Cambridge, MA / Londres, 2011.

Nawotka 1999

Nawotka, K., Boule und Demos in Miletus and its Pontic Colonies from Classsical Age until the Third Century AD, Wrozlaw / Varsovie / Cracovie, 1999.

Ogden 2002

Ogden, D., Magic, Witchcraft, and Ghosts in the Greek and Roman Worlds. A Sourcebook, Oxford, 2002.

Olson 2012

Olson, A., "How Eupalinos Navigated His Way Through the Mountain - An Empirical Approach to the Geometry of Eupalinos", Anatolia Antiqua XX, 2012, 25-34.

Otten 1958

Otten, H., Hethitische Totenrituale, Berlin, 1958.

Papazarkadas 2011

Papazarkadas, N., Sacred and Public Land in Ancient

Athens, Oxford, 2011.

Parker 1983

Parker, R., Miasma. Pollution and Purification in early Greek Religion, Oxford, 1983.

Parker 2005

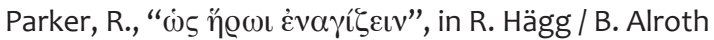
(éds.), Greek Sacrificial Ritual, Olympian and Chthonian [Proceedings of the Sixth International Seminar on ancient Greek Cult, organized by the Department of Classical Archaeology and Ancient History, Göteborg University, 25-27 April 1997], Stockholm, 2005, 37-45.

Parker 2011

Parker, R., On Greek Religion, Ithaca / Londres, 2011.

Pedley 1990

Pedley, J.G., Paestum. Greeks and Romans in Southern Italy, Londres, 1990.

Pellecchia et al. 2007

Pellecchia, M. / Negrini, R. / Colli, L. / Patrini, M. /

Milanesi, E. / Achilli, A. / Bertorelle, G. / Cavalli Sforza, 
L.L. / Piazza, A. / Torroni, A. / Ajmone Marsan, "The mystery of Etruscan origins - novel clues from Bos taurus mitochondrial DNA", Proceedings of the Royal Society of London B. Nr. 274, Londres 2007, 1175-1179 <http://rspb. royalsocietypublishing.org/content/274/1614/1175.full. pdf+html> (02.06.2012)

Peters 2002

Peters, M., "Aus der Vergangenheit von Heroen und Ehegöttinnen”, in Fritz, M. / Zeilfelder, S. (éds.), 'Novalis Indogermanica'. Festschrift für Günther Neumann zum 80. Geburtstag, Graz, 2002, 357-380.

Pfister 1909

Pfister, F., Der Reliquienkult im Altertum, Giessen, 1909.

Philipp 1984

Philipp, H., “Die Kosmographie Homers”, MDAI(A) 99, 1984, 1-4.

Philippson 1936

Philippson, A., Das südliche Ionien. Mit Karte: Jonien, südlicher Teil (1:100.000), bearbeitet von Karl Lyncker, Milet III 5, Berlin, 1936.

Pipili 1987

Pipili, M., Laconian Iconography of the Sixth Century B.C., Oxford, 1987.

Polignac 1995

Polignac, F., Cults, Territory, and the Origins of the Greek City-State, Chicago / Londres, 1995.

Rabe 2008

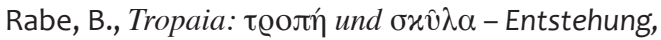
Funktion und Bedeutung des griechischen Tropaions, Rhaden, Westphalie, 2008.

Rausch 2000

Rausch, M., "Das Hypogäum auf der Agora von Poseidonia. Ein Kultort der Tritopatores?”, Kernos 13, 2000, 107-116.

Rehm/Harder 1958

Rehm, A. / Harder, R., Didyma, Zweiter Teil: Die Inschriften, Berlin, 1958.

Richter/Smith 1984

Richter, G.M.A. / Smith, R.R.R., The Portraits of the Greeks, Ithaca / New York, 1984.

Riethmüller 2005

Riethmüller, J., Asklepios. Heiligtümer und Kulte, Vols. I-II, Heidelberg, 2005.

Ritter 2009

Ritter, S., Alle Bilder führen nach Rom. Eine kurze

Geschichte des Sehens, Stuttgart, 2008.
Rohde 1925

Rohde, E., Psyche. Seelencult und Unsterblichkeitsglaube der Griechen, Vols. I-II, Tübingen, 1925 9/10 (1890-1893').

Rhodes/Osborne 2003

Rhodes, P.J. / Osborne, R., Greek Historical Inscriptions 404-323 BC, Oxford, 2003.

Sauzeau/Sauzeau 2002

Sauzeau, P. / Sauzeau, A., "Le symbolisme des métaux et le mythe des races métalliques", RHR 219, 2002, 259-297.

Schaaf 1992

Schaaf, H., Untersuchungen zu Gebäudestiftungen in hellenistischer Zeit, Cologne / Weimar / Vienne, 1992.

Schlesier 1997

Schlesier, R., "Chthonische Götter, II. Griechenland", in Der Neue Pauly 2, Stuttgart, 1997, 1186-1190 s.v.

Schmidt 1990

Schmidt, E.A., Notwehrdichtung. Moderne Jambik von Chénier bis Borchardt (mit einer Skizze zur antiken Jambik), Munich, 1990.

Schollmeyer 2011

Schollmeyer, P., "II Das Monument im Vorhof des Bouleuterions", in Bol, R., Funde aus Milet, Teil 2: Marmorskulpturen der römischen Kaiserzeit aus Milet. Aufstellungskontext und programmatische Aussage, Milet V 2, Berlin / New York, 2011, 18-24 figs. 4-5 pls. 2-4.

Schörner 2007

Schörner, H., 'Sepulturae graecae intra urbem'. Untersuchungen zum Phänomen der intraurbanen Bestattungen bei den Griechen [Boreas Beiheft 9], Möhnesee, 2007.

Schweitzer 1922

Schweitzer, B., Herakles. Aufsätze zur griechischen Religions- und Sagengeschichte, Tübingen, 1922.

Seeher 1993

Seeher, J., "Körperbestattung oder Kremation - ein Gegensatz?”, MDAI(I) 43, 1993, 219-226.

Seiffert 2005

Seiffert, A., "Heroon", in ThesCRA IV (2005) 24-38 s.v.

Seiffert 2009

Seiffert, A., "Gefürchtet, bewundert, vergöttert.

Die religiöse Verehrung der Helden", in Badisches Landesmuseum Karlsruhe (éd.), Zeit der Helden. Die 'dunklen Jahrhunderte' Griechenlands 1200-700 v. Chr., Katalog zur Ausstellung im Badischen Landesmuseum Schloss Karlsruhe, 25.10.2008-15.2.2009, Karlsruhe, 2008, 352-360. 
Slawisch 2011

Slawisch, A., "Aus unruhigen Zeiten: Die

'Ächtungsinschrift' aus Milet, ein Erlass aus dem frühesten

5. Jahrhundert v. Chr.", MDAI(I) 61, 2011, 425-432.

Snodgrass 1980

Snodgrass, A., Archaic Greece. The Age of Experiment, Londres / Melbourne / Toronto, 1980.

Snodgrass 1998

Snodgrass, A., Homer and the Artists. Text and Picture in Early Greek Art, Cambridge, 1998.

Söldner 2009

Söldner, M., "Naiskoi für Menschen. Eine heroisierende Fiktion im unteritalischen Vasenbild", in C. Schmitz /A. Bettenworth (éds.), Mensch - Heros - Gott. Weltentwürfe und Lebensmodelle im Mythos der Vormoderne, Stuttgart, 2009, 35-51.

\section{Sokolicek 2009}

Sokolicek, A., "Zwischen Stadt und Land: Neues zum Magnesischen Tor in Ephesos. Erste Ergebnisse”, JÖAl 78, 2009, 321-347.

Sourvinou-Inwood 1995

Sourvinou-Inwood, Ch., 'Reading' Greek Death, to the End of the Classical Period, Oxford, 1995.

\section{Steingräber 2002}

Steingräber, S., “Ahnenkult und bildliche Darstellungen von Ahnen in etruskischen und unteritalischen Grabgemälden aus vorrömischer Zeit”, in J.M. Højte (éd.), Images of Ancestors, Aarhus, 2002, 127-158.

Stoddart 2009

Stoddart, S.K.F., The Historical Dictionary of the Etruscans [Historical Dictionaries of Ancient Civilizations 24], Plymouth, 2009.

Stroszeck 2010

Stroszeck, J., "Das Heiligtum der Tritopatores im Kerameikos von Athen", in H. Frielingshaus / J. Stroszeck (éds.), Neue Forschungen zu griechischen Städten und Heiligtümern. Festschrift für Burkhardt Wesenberg zum 65. Geburtstag, Möhnesee, 2010, 55-83

Stucchi 1965

Stucchi, S., L'Agorà di Cirene I. I lati nord ed est della platea inferiore, Rome, 1965.

Studniczka 1890

Studniczka, F., Kyrene. Eine altgriechische Göttin, Leipzig, 1890.

Stümpel/Erkul 2008

Stümpel, H. / Erkul, E., "Geophysikalische Prospektion in Milet 2003-2005”, AA 2008/2, 25-32.
Tell 2007

Tell, H., "Sages at the Games: Intellectual Displays and Dissemination of Wisdom in Ancient Greece", Classical Antiquity 26, 2007, 249-275.

Themelis 2006

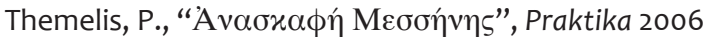
(2008), 31-67.

Themelis 2010

Themelis, P., "Die Agora von Messene”, in H. Frielingshaus I J. Stroszeck (éds.), Neue Forschungen zu griechischen Städten und Heiligtümern [Festschrift für Burkhardt Wesenberg zum 65. Geburtstag], Möhnesee, 2010, 102-125.

Thönges-Stringaris 1965

R.N. Thönges-Stringaris, "Das griechische Totenmahl”, $\operatorname{MDAI}(A)$ 80, 1965, 1-99.

Tölle-Kastenbein 1994

Tölle-Kastenbein, R., Das archaische Wasserleitungsnetz für Athen und seine späteren Bauphasen, Mayence, 1994.

Thomsen 2011

Thomsen, A., Die Wirkung der Götter. Bilder mit

Flügelfiguren auf griechischen Vasen des 6. und 5.

Jahrhunderts v. Chr., Berlin / Boston, 2011.

Tuchelt 1975

Tuchelt, K., "Bouleuterion und Ara Agusti. Bemerkungen zur Rathausanlage von Milet”, MDAI(I) 25, 1975, 91-140.

Tuchelt 1979

Tuchelt, K., Frühe Denkmäler Roms in Kleinasien. Beiträge zur archäologischen Überlieferung aus der Zeit der Republik und des Augustus. Teil 1: Roma und Promagistrate [MDAI(I) Beiheft 23], Tübingen, 1979.

Tuchelt 1981

Tuchelt, K., “Zum Problem 'Kaisareion - Sebasteion”', $\operatorname{MDAI}(I)$ 31, 1981, 167-186.

Tuttahs 2007

Tuttahs, G., Milet und das Wasser - Ein Leben in Wohlstand und Not in Antike, Mittelalter und Gegenwart [Schriften der Deutschen Wasserhistorischen Gesellschaft (DWhG) E.v., Sonderband 5], Siegburg, 2007.

Usener 1903

Usener, H., "Dreiheit”, RhM 58, 1903, 1-47, 161-208, 321-362.

Ventris/Chadwick 1973

Ventris, M. / Chadwick, J., Documents in Mycenaean Greek ${ }^{2}$ Cambridge, 1973.

Vonderstein 2006

Vonderstein, M., Der Zeuskult bei den Westgriechen

[Palilia 17], Wiesbaden, 2006. 
Watkins 1995

Watkins, C., How to Kill a Dragon. Aspects of Indo-European Poetics, Oxford, 1995.

Weber $2004 a$

Weber, B.F., Milet I. Die Bauwerke in Milet. Teil 10: Die römischen Heroa von Milet, Berlin / New York, 2004.

Weber 2004b

Weber, B.F., "Der Stadtplan des kaiserzeitlichen Milet", in E.-L. Schwandner / K. Rheidt (éds.), Macht der Architektur - Architektur der Macht, Bauforschungskolloquium in Berlin vom 30. Oktober bis 2. November 2002, veranstaltet vom Architektur-Referat des DAI [Diskussionen zur Archäologischen Bauforschung 8], Mayence, 2004, 231240.

Weber 2007

Weber, B.F., "Der Stadtplan von Milet”, in J. Cobet / V.v. Graeve / W.D. Niemeier / K. Zimmermann (éds.), "Frühes Ionien": Eine Bestandsaufnahme. Akten des Symposions Panionion (Güzelçamlı), 26. September bis 1. Oktober 1999 [Milesische Forschungen 5], Mayence, 2007, 327-362.

\section{Weber 2008}

Weber, U., "Eine neue Orakelinschrift aus Didyma zum Kult der Horen in der späten Kaiserzeit”, MDAI(I) 58, 2008, 243-260.

\section{Weinreich 1973}

Weinreich, O., "Review of Schweitzer 1922", Philologische Wochenschrift 44, 1924, 807-837 [= G. Wille (éd.), Otto Weinreich. Ausgewählte Schriften II, 1922-1937, Amsterdam, 1973, 69-102].

Wernicke 1896 Wernicke, P., "Asterion (10)”, in Paulys Realencyclopädie der Classischen Altertumswissenschaften II 2, Stuttgart, 1896,1785 S.v.

West 1978

West, M.L., Hesiod. Works and Days, Edited with

Prolegomena and Commentary, Oxford, 1987.

Wiegand 19010

Wiegand, Th., "Zweiter vorläufiger Bericht über die von den Königlichen Museen begonnenen Ausgrabungen in Berlin", in Sitzungsberichte der königlich-preussischen Akademie der Wissenschaften Berlin, 1901, 903-913.
Wiegand 1901b

Wiegand, Th., “Ausgrabungen zu Milet”, AA 1901, 191-199.

Wiegand 1902

Wiegand, Th., "Zweiter vorläufiger Bericht über die Ausgrabungen der königlichen Museen zu Milet", AA, 1902, 147-155.

Wilski 1906

Wilski, P., Karte der Milesischen Halbinsel (1:50.000),

Milet I 1, Berlin, 1906.

Witschel 1995

Witschel, C., "Statuen auf römischen Platzanlagen unter besonderer Berücksichtigung von Timgad (Algerien)", in K. Stemmer (éd.), Standorte. Kontext und Funktion antiker Skulptur, Exhibition Catalogue Abguss-Sammlung antiker Plastik Berlin, 27.11.1994-11.6.1995, Berlin, 1995, 332-387.

Wrede 1981

Wrede, H., 'Consecratio in formam deorum'. Vergöttlichte Privatpersonen in der römischen Kaiserzeit, Mayence, 1981.

Wüst 1939

Wüst, E., "Tritopatores”, in Paulys Realencyclopädie der Classischen Altertumswissenschaften, VII A 1, Stuttgart, 1939, 324-327 s.v.

Wycherley 1957

Wycherley, R.E., The Athenian Agora III: Literary and Epigraphical Testimonia, Princeton, NJ, 1957.

Xagorari 1994

Xagorari, M., "Sophia”, LIMC VII 1 (1994), 798 s.v.

Yakubovich 2010

Yakubovich, I., Sociolinguistics of the Luvian Language, Leyde / Boston, 2010.

Zanker 2004

Zanker, P., Die Apotheose der römischen Kaiser. Ritual und städtische Bühne, Munich, 2004.

Zanker 2007

Zanker, P., Die römische Kunst, Munich, 2007. 